\title{
PESQUISADORES BRASILEIROS EM PERIÓDICOS CIENTÍFICOS DE CIÊNCIAS DA COMUNICAÇÃO
}




\title{
Renata Carvalho da Costa
}

\section{PESQUISADORES BRASILEIROS EM PERIÓDICOS CIENTÍFICOS DE CIÊNCIAS DA COMUNICAÇÃO}

\author{
Tese apresentada à Universidade de São Paulo \\ para obtenção do título de Doutor em Ciências \\ no Programa de Pós-Graduação em Ciências da Comunicação \\ Área de concentração: Teoria e Pesquisa em Comunicação
}

\section{Orientadora:}

Prof $^{a}$. Dr ${ }^{\mathrm{a}}$. Sandra Lucia Amaral de Assis Reimão

São Paulo

2015 
Autorizo a reprodução e divulgação total ou parcial deste trabalho, por qualquer meio convencional ou eletrônico,

para fins de estudo e pesquisa, desde que citada a fonte.

Catalogação na Publicação

Serviço de Biblioteca e Documentação

Escola de Comunicações e Artes da Universidade de São Paulo

Dados fornecidos pelo(a) autor(a)

Costa, Renata C. da

Pesquisadores brasileiros em periódicos de Ciências da Comunicação / Renata Costa.

- São Paulo: R. Costa, 2015.

126 p. + CD.

Tese (Doutorado) - Programa de Pós-Graduação em Ciências da Comunicação - Escola de Comunicações e Artes / Universidade de São Paulo.

Orientadora: Sandra Lucia Amaral de Assis Reimão

Bibliografia

1. periódicos científicos 2. epistemologia da comunicação 3. teoria da comunicação I. Reimão, Sandra Lucia Amaral de Assis II. Título.

CDD 21.ed. - 302.2 
COSTA, Renata Carvalho da

Pesquisadores brasileiros em periódicos científicos de Ciências da Comunicação

Tese apresentada à Universidade de São Paulo para obtenção do título de Doutor em Ciências no Programa de Pós-Graduação em

Ciências da Comunicação

BANCA EXAMINADORA

Presidente:

Prof $^{\mathrm{a}} \mathrm{Dr}^{\mathrm{a}}$ Sandra Lucia Amaral de Assis Reimão

Membros:

São Paulo, de de 2015 . 


\section{Dedicatória}

Para minhas filhas

Laura, que mudou meus caminhos e valores

6

Vitória, tão corajosa, que alterou minha rotação e me preenche com tanto amor

Para minhas avós Bina e Rosinha, mulheres tão cheias de sonhos e desejos... ... gostaria que tivessem vivido o século XXI 


\section{Agradecimentos}

Não posso deixar de agradecer em primeiro lugar a duas pessoas sem as quais (sem exagero) esta tese não terminaria: minha irmã Soraya e meu esposo Fabiano. Obrigada pela generosidade na ajuda com as referências e pela paciência comigo. Obrigada por sempre me apoiarem com amor e mão na massa!

Agradeço minha orientadora, $\operatorname{Prof}^{a} \operatorname{Dr}^{a}$ Sandra Reimão, pela oportunidade, apoio e compreensão durante esses longos quatro anos. À Prof ${ }^{a} \operatorname{Dr}^{a}$ Maria Immacolata pela amizade, carinho e inspiração. Muito obrigada, professoras!

Às queridas Rosely Vieira e Juliana Doretto, amigas para toda hora, dentro e fora da Academia.

Aos meus pais, Renato e Marli, por terem investido prioritariamente na Educação das filhas, pelo amor incondicional, por estarem ao meu lado nos momentos difíceis e por embarcarem comigo em todas as minhas aventuras. Às minhas irmãs Denise e Eliane, Paulo Renato e Paulinho, pelo amor e companheirismo. Ao Tony Rodrigues pela generosidade e linda diagramação.

À Capes, pela bolsa.

E, finalmente, à minha Vivi, que transformou a finalização da tese em uma aventura... Agora acabou e a mamãe pode brincar com você! 


\section{Resumo}

Costa, Renata C. da. Pesquisadores brasileiros em periódicos científicos de Ciências da Comunicação. São Paulo, 2015. Tese (Doutorado) - Programa de Pós-Graduação em Ciências da Comunicação, Universidade de São Paulo.

$\mathrm{O}$ ESTUDO TEM POR objetivo principal descrever o perfil do pesquisador brasileiro que publica nos periódicos científicos da área de Ciências da Comunicação. Consideramos como pesquisador brasileiro aquele inserido no sistema acadêmico e de pesquisa do país, independentemente de seu local de nascimento. O corpus é composto pelos cinco periódicos científicos brasileiros mais bem classificados dessa área, ou seja, aqueles que compõem o estrato A2, segundo o WebQualis triênio 2010-2012, sistema de avaliação de periódicos da Coordenação de Aperfeiçoamento de Pessoal de Nível Superior (Capes). São eles: E-Compós, Revista da Famecos, Galáxia, Revista da Intercom e MATRIZes. Foram estudados artigos de todas as edições publicadas entre os anos 2000 e 2012. Os periódicos tiveram seus artigos analisados por meio dos títulos, autores, titularidade e filiação acadêmica desses, palavras-chave e referências bibliográficas. A partir dessa listagem, traçou-se o perfil mais recorrente do pesquisador que publica nos periódicos A2, levando-se em conta titularidade, universidade e tema dos artigos, a partir das palavras-chave e título. Pode-se afirmar, dessa maneira, que o perfil predominante é feminino, com título de doutor, sendo a maioria dos artigos publicada por pesquisadores da Universidade de São Paulo sobre estudo dos meios (midialogia). Por trás da pesquisa empírica, o objeto teórico é a epistemologia das Ciências da Comunicação, considerando o conceito de campo científico segundo Bourdieu e levando em conta para o funcionamento e institucionalização deste as questões colocadas pela sociologia da Ciência. Quanto às referências bibliográficas, podemos destacar que os autores europeus, em especial os franceses, constituem a maioria das citações feitas pelos autores brasileiros nos periódicos do corpus, porém são poucas as obras recorrentes nas referências bibliográficas, o que, por um lado, significa que os pesquisadores têm citado novos autores e obras, mas o dado também aponta para a falta de unidade da área de Comunicação em torno de nomes e obras fundadoras e referenciais. 
Pesquisadores brasileiros em Periódicos Científicos de Ciências da Comunicação

Palavras-chave: periódico científico; pesquisa em Comunicação; epistemologia da Comunicação 


\section{Abstract}

Costa, Renata C. da. Brazilian researchers in scientific journals of Communication Sciences. São Paulo, 2015. Tese (Doutorado) - Programa de Pós-Graduação em Ciências da Comunicação, Universidade de São Paulo.

$\neg$ HE STUdy's MAIN objective is to describe the profile of the Brazilian researcher 1 publishing in scientific journals of Communication Sciences area. We consider Brazilian researchers those inserted into the country's academic and research systems, regardless their place of birth. The corpus of this research is composed by the five Brazilian scientific journals highly rated in this area, ie those that comprise the stratum A2, according to the WebQualis 2010-2012 period, periodic assessment system of Higher Education Personnel Training Coordination (Capes). They are E-Compós, Revista Famecos, Galáxia, Revista da Intercom and MATRIZes. We studied articles from all editions published between 2000 and 2012. The journals had their articles analyzed through the titles, authors, academic degree and affiliation of those authors, keywords and references. From this list, we traced the most applicant's research profile that publishes in journals A2, taking into account academic degree, university and subject of articles, from keywords and title. It can be said, thus, that the predominant profile is feminine, with Phd's degree and most of the articles are published by researchers from University of São Paulo about media studies (medialogy). Behind the empirical research, the theoretical object is the epistemology of Communication Sciences, considering the concept of scientific field according to Bourdieu and taking into account its institutionalization and the issues raised by the sociology of science. As for references, we can highlight that European authors, especially French, constitute the majority of citations made by Brazilian authors in the corpus, but there are few recurring works in the references, which on the one hand, means researchers have cited new authors and works, but the data also points to the lack of unity of the Communications area around central names and reference works.

Keywords: scientific journals; Communication research; Communication epistemology 


\section{Lista de tabelas}

Tabela 1 - Número de periódicos de Ciências da Comunicação entre estratos $\mathrm{B}_{1}$ e $\mathrm{B}_{5}$

Tabela 2 - Algumas informações sobre os periódicos científicos nacionais em

Ciências da Comunicação no estrato WebQualis Az …………………..... 42

Tabela 3 - Indexadores exigidos por estrato em WebQualis ....................................45

Tabela 4 - Cobertura por países do Google Scholar Metrics,

Web Of Science e Scopus

Tabela 5 - Índice H dos periódicos brasileiros de Comunicação no

Google Scholar Metricis

Tabela 6 - Programas de pós-graduação em Ciências da Comunicação

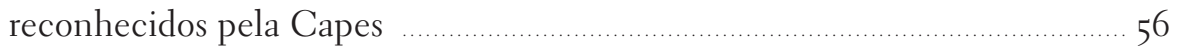

Tabela 7 - Associações filiadas à Socicom …………....................................... 58

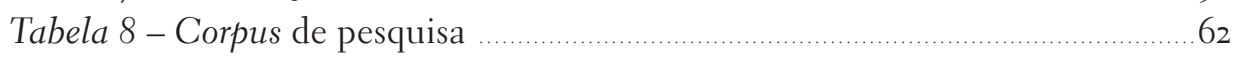

Tabela 9 - Número de edições e artigos do corpus ........................................ 65

Tabela 10 - Número de artigos e porcentagem de autores por titulação ………... 66

Tabela 11 - Número de artigos e porcentagem por titulação em artigos

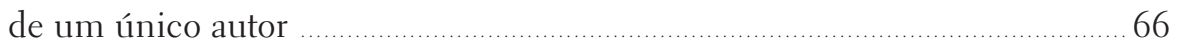

Tabela 12 - Número de artigos e porcentagem por autoria única e coautoria ....67 67

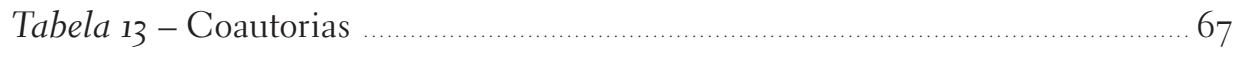

Tabela 14 - Autores que aparecem em maior número de revistas .......................... 68

Tabela 15 - Dez universidades de maior ocorrência no periódico E-Compós

(de um total de 55 universidades representadas nas edições analisadas) .......69

Tabela 16 - Dez universidades de maior ocorrência no periódico Famecos

(de um total de 65 universidades representadas nas edições analisadas) ........69 
Tabela 17 - Dez universidades de maior ocorrência no periódico Galáxia (de um total de 45 universidades representadas nas edições analisadas) ….... 70 Tabela 18 - Dez universidades de maior ocorrência no periódico Revista da Intercom (de um total de 81 universidades representadas nas edições analisadas) …...........70 Tabela 19 - Dez universidades de maior ocorrência no periódico MATRIZes (de um total de 23 universidades representadas nas edições analisadas) ….....71

Tabela 20 - Universidades com maior ocorrência em todos os periódicos ……..... 71

Tabela 21 - Subáreas da Comunicação propostas pelo Conselho da Compós tabela aplicada como classificação temática dos artigos analisados ………......72

Tabela 22 - Número de artigos por revista e por área de classificação temática

Tabela 23 - Porcentagem de artigos por revista por área de classificação temática - E-Compós

Tabela 24 - Porcentagem de artigos por revista por área de classificação temática - Famecos

Tabela 25 - Porcentagem de artigos por revista por área de classificação temática - Galáxia

Tabela 26 - Porcentagem de artigos por revista por área de classificação temática - Intercom

Tabela 27 - Porcentagem de artigos por revista por área de classificação temática - MATRIZes

Tabela 28 - Número de artigos e amostra dimensionada por revista …………..... 74

Tabela 29 - Autores por sexo 79

Tabela 30 - Número de universidades representadas por autores de artigos nos periódicos

Tabela 31 - Universidades com maior ocorrência considerando os periódicos E-Compós, Galáxia, Intercom e MATRIZes ……………………….......... 81

Tabela 32 - Total de artigos por temas considerando todo o corpus ……............82 82

Tabela 33 - Temas mais recorrentes nos cinco periódicos ……...................... 83

Tabela 34 - Temas menos recorrentes nos cinco periódicos ……………....... 85

Tabela 35 - Estatísticas do número de citações por artigo das revistas

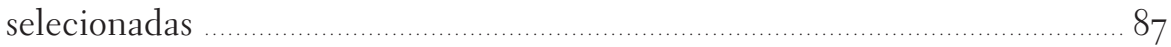

Tabela 36 - Autores mais citados ……....................................................... 88

Tabela 37 - Textos mais citados nas referências bibliográficas ............................. 90 


\section{LISTA DE SIGLAS}

\begin{tabular}{|c|c|}
\hline AESA & Autarquia de Ensino Superior de Arcoverde - PE \\
\hline Bireme & $\begin{array}{c}\text { Centro Latino-americano e do Caribe de Informação em Ciências } \\
\text { da Saúde }\end{array}$ \\
\hline Capes & Coordenação de Aperfeiçoamento de Pessoal de Nível Superior \\
\hline Ciespal & $\begin{array}{c}\text { Centro Internacional de Estudios Superiores de Comunicación } \\
\text { para América Latina }\end{array}$ \\
\hline Clacso & Consejo Latinoamericano de Ciencias Sociales \\
\hline Clase & Citas Latinoamericanas en Ciencias Sociales y Humanidades \\
\hline $\mathrm{CNPq}$ & Conselho Nacional de Desenvolvimento Científico e Tecnológico \\
\hline Compós & Associação Nacional dos Programas de Pós-Graduação em Comunicação \\
\hline CSA & Ciências Sociais Aplicadas \\
\hline Doaj & Directory of Open Access Journals \\
\hline ESPM & Escola Superior de Propaganda e Marketing \\
\hline Faenac & Faculdade Anhanguera de São Caetano \\
\hline Famecos & Faculdade de Comunicação Social \\
\hline Fapemig & Fundação de Amparo à Pesquisa do Estado de Minas Gerais \\
\hline Fapesp & Fundação de Amparo à Pesquisa do Estado de São Paulo \\
\hline $\mathrm{FCL}$ & Faculdade Cásper Líbero \\
\hline GSM & Google Scholar Metrics \\
\hline lbict & Instituto Brasileiro de Informação em Ciência e Tecnologia \\
\hline lbope & Instituto Brasileiro de Opinião Pública e Estatística \\
\hline Icinform & Instituto de Ciências da Informação \\
\hline Intercom & Sociedade Brasileira de Estudos Interdisciplinares da Comunicação \\
\hline ISSN & International Standard Serial Number \\
\hline JCR & Journal Citation Reports \\
\hline Latindex & $\begin{array}{c}\text { Sistema Regional de Informação em linha para revistas científicas da } \\
\text { América Latina, Caribe, Espanha e Portugal }\end{array}$ \\
\hline Lilacs & Literatura Latino-Americana e do Caribe em Ciências da Saúde \\
\hline OEI & Organização dos Estados Ibero-Americanos \\
\hline OJS & Open journal system \\
\hline PUC-MG & Pontifícia Universidade Católica de Minas Gerais \\
\hline PUC-Campinas & Pontifícia Universidade Católica de Campinas \\
\hline PUC-RJ & Pontifícia Universidade Católica do Rio de Janeiro \\
\hline PUCRS & Pontifícia Universidade Católica do Rio Grande do Su \\
\hline PUC-SP & Pontifícia Universidade Católica de São Paulo \\
\hline
\end{tabular}




\begin{tabular}{|c|c|}
\hline Redalyc & Red de Revistas Cientificas de América Latina y Caribe, España y Portugal \\
\hline Scielo & Scientific Electronic Library Online \\
\hline Seer & Sistema Eletrônico de Editoração de Revistas \\
\hline Sibi & Sistema Integrado de Bibliotecas da Universidade de São Paulo \\
\hline Socicom & $\begin{array}{c}\text { Federação Brasileira das Associações Científicas e Acadêmicas } \\
\text { de Comunicação }\end{array}$ \\
\hline UAM & Universidade Anhembi Morumbi \\
\hline $\mathrm{UCB}$ & Universidade Católica de Brasilia \\
\hline UCG & Universidade Católica de Goiás \\
\hline UCPel & Universidade Católica de Pelotas \\
\hline UCS & Universidade de Caxias do Sul \\
\hline UEL & Universidade Estadual de Londrina \\
\hline UENF & Universidade Estadual do Norte Fluminense \\
\hline UEPB & Universidade Estadual da Paraíba \\
\hline UEPG & Universidade Estadual de Ponta Grossa \\
\hline Uerj & Universidade do Estado do Rio de Janeiro \\
\hline UESC & Universidade Estadual de Santa Cruz \\
\hline UFAM & Universidade Federal do Amazonas \\
\hline UFBA & Universidade Federal da Bahia \\
\hline UFC & Universidade Federal do Ceará \\
\hline UFES & Universidade Federal do Espírito Santo \\
\hline UFF & Universidade Federal Fluminense \\
\hline UFG & Universidade Federal de Goiás \\
\hline UFJF & Universidade Federal de Juiz de Fora \\
\hline UFMA & Universidade Federal do Maranhão \\
\hline UFMG & Universidade Federal de Minas Gerais \\
\hline UFOP & Universidade Federal de Ouro Preto \\
\hline UFPA & Universidade Federal do Pará \\
\hline UFPB & Universidade Federal da Paraíba \\
\hline UFMS & Universidade Federal do Mato Grosso do Sul \\
\hline UFPE & Universidade Federal de Pernambuco \\
\hline UFPI & Universidade Federal do Piauí \\
\hline UFPR & Universidade Federal do Paraná \\
\hline UFRGS & Universidade Federal do Rio Grande do Sul \\
\hline UFRJ & Universidade Federal do Rio de Janeiro \\
\hline
\end{tabular}




\begin{tabular}{|c|c|}
\hline UFRN & Universidade Federal do Rio Grande do Norte \\
\hline UFRPE & Universidade Federal Rural de Pernambuco \\
\hline UFS & Universidade Federal de Sergipe \\
\hline UFSC & Universidade Federal de Santa Catarina \\
\hline UFSCar & Universidade Federal de São Carlos \\
\hline UFSM & Universidade Federal de Santa Maria \\
\hline UFV & Universidade Federal de Viçosa \\
\hline UGF & Universidade Gama Filho \\
\hline Umesp & Universidade Metodista de São Paulo \\
\hline Unama & Universidade da Amazônia \\
\hline UnB & Universidade Federal de Brasília \\
\hline Unesa & Universidade Estácio de Sá \\
\hline Unesc Colatina & Centro Universitário do Espírito Santo \\
\hline Unesco & Organização das Nações Unidas para Educação, Ciências e Cultura \\
\hline Unesp & Universidade Estadual Paulista "Júlio de Mesquita Filho" \\
\hline Uni-BH & Centro Universitário de Belo Horizonte \\
\hline Unicamp & Universidade Estadual de Campinas \\
\hline UniCarioca & Centro Universitário Carioca \\
\hline Uniderp & Universidade para o Desenvolvimento do Estado e da Região do Pantanal \\
\hline UniFIAM-FAAM & Centro Universitário Fiam-Faam \\
\hline Unifor & Universidade de Fortaleza \\
\hline Unimep & Universidade Metodista de Piracicaba \\
\hline Unioeste & Universidade Estadual do Oeste do Paraná \\
\hline Unip & Universidade Paulista \\
\hline Unipac & Universidade Presidente Antonio Carlos \\
\hline Unisinos & Universidade do Vale do Rio dos Sinos \\
\hline Uniso & Universidade de Sorocaba \\
\hline Univali & Universidade do Vale do Itajaí \\
\hline Univercidade & Centro Universitário da Cidade \\
\hline Fape & Faculdade de Presidente Epitácio \\
\hline USC & Universidade Sagrado Coração \\
\hline USCS & Universidade Municipal de São Caetano do Sul \\
\hline USP & Universidade de São Paulo \\
\hline UTP & Universidade Tuiuti do Paraná \\
\hline
\end{tabular}

\section{XIX}




\section{Sumário}

1.1. O periódico científico e seu lugar na Ciência ……………………... 27

1.2. Definindo os periódicos ................................................................ 30

1.3. O nascimento dos periódicos científicos de Ciências da

Comunicação no Brasil

Capítulo 2 -O EDITOR CIENTÍFICO E AS DEMANDAS

EXTERNAS À EDIÇÃO

2.1. O editor científico e o nascimento

de um periódico 40

2.2. Demandas externas e indexadores.

2.2.1. Scielo e Scopus

2.2.2. Web of Science e JCR

2.2.3. Google Scholar

Capitulo 3 -O PERFIL INSTITUCIONAL DAS CIÊNCIAS

DA COMUNICAÇÃO NO BRASIL ……

3.1. A Comunicação como campo ……………............................. 52

3.2. A institucionalização das Ciências da Comunicação no Brasil ...........54

3.2.1. As associações como parte do crescimento da área ...................... 58

3.3. Um retrato do campo acadêmico no século XXI …….......................59 
Capitulo 4 - DESCRIÇÃO E ANÁLISE DOS PERIÓDICOS

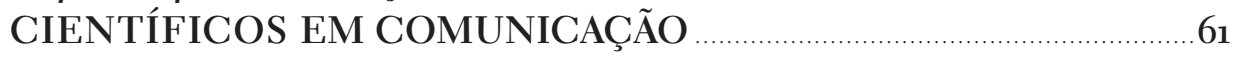

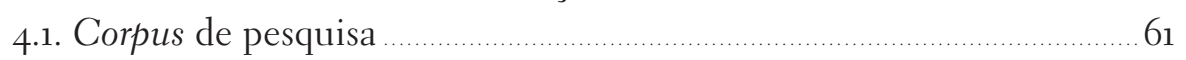

4.1.1. E-Compós _.................................................................. 62

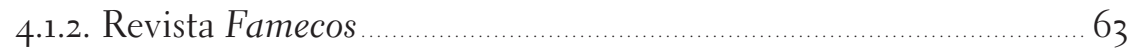

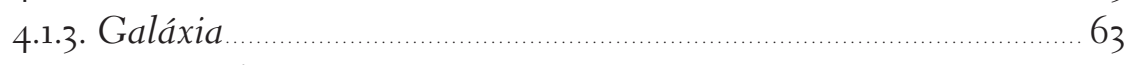

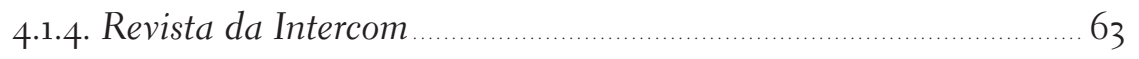

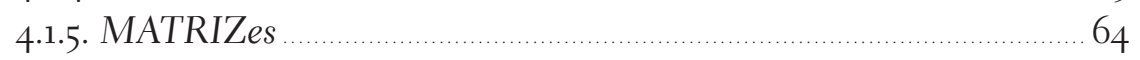

4.2. Questões a serem consideradas a respeito do corpus ........................... 64

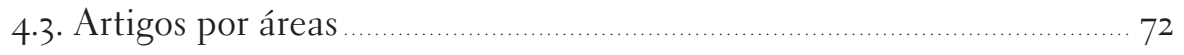

4.4. Bibliografia utilizada pelos autores brasileiros dos artigos ................. 74

Capítulo 5 - DISCUSSÃO - O AUTOR BRASILEIRO NOS

PERIÓDICOS CIENTÍFICOS - QUEM SÃO, TEMAS E

REFERÊNCIAS BIBLIOGRÁFICAS PREPONDERANTES _.................77

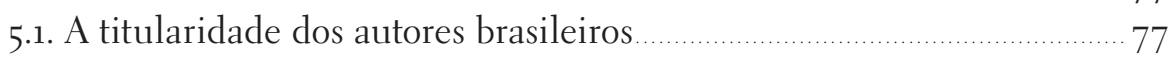

5.2. Autoria única e coautorias ................................................... 78

5.2.1. Os autores com maior participação _........................................79

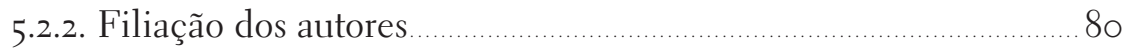

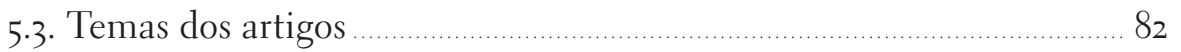

5.4. Quem é o pesquisador brasileiro ……………………………........ 86

5.5. Autores mais citados nas referências bibliográficas de artigos

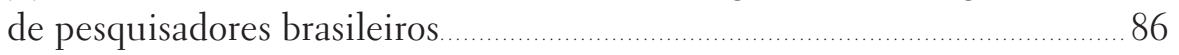

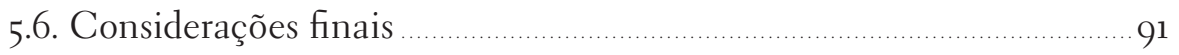

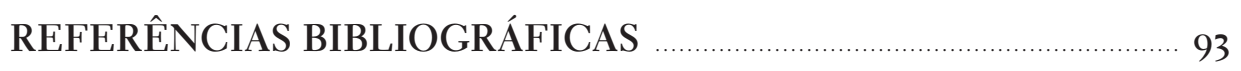

\section{ANEXOS}

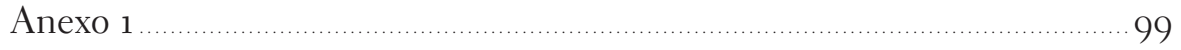

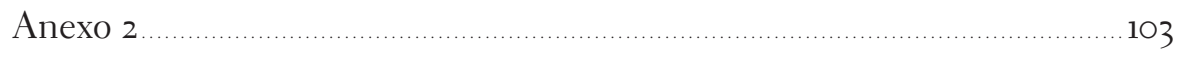

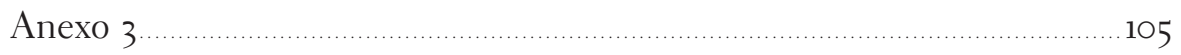

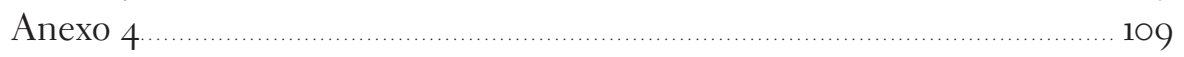




\section{INTRODUÇÃO}

$\mathrm{F}$

STE TRABALHO PARTE de uma pergunta aparentemente simples: quem é o autor brasileiro nos periódicos científicos em Ciências da Comunicação?

Se estamos considerando o que é publicado em um periódico científico, deduz-se naturalmente, sem qualquer necessidade de análise, que esse autor é um pesquisador inserido no conjunto de instituições acadêmicas, de ensino e de investigação do país. Em pesquisa, no entanto, uma pergunta sempre suscita outras várias: de quais instituições? Em quais regiões? Qual a titularidade desse autor? Sobre o que ele escreve?

Estamos no século XXI e ainda discutimos no Brasil o objeto de estudo da Comunicação e, pelo que se lê nos livros e artigos de epistemologia e teorias do campo, ou pelo que se vê em congressos e palestras da área, definir esse objeto não é tão simples. Estudos sobre os meios de comunicação são abundantes - este trabalho também confirma isso como um de seus resultados -, mas qual a situação da construção teórica desse campo? O que há de contribuições teóricas originais? Como também mostra esta tese, no capítulo 5, ainda são poucos os estudos com a preocupação de construir teorias próprias ao campo da Comunicação, porém eles existem e estão emergindo.

Partindo do objetivo principal que é a pergunta feita acima, tomamos como objeto teórico deste estudo a epistemologia do campo das Ciências da Comunicação (a definição de campo segundo Bourdieu está no capítulo 3; assim como a formação do campo no Brasil e sua institucionalização). Como objeto empírico, escolhemos os periódicos científicos da área no país, definindo como corpus de estudo aqueles mais bem avaliados, tendo como critério o WebQualis trienal 2010-2012, um sistema da Coordenação de Aperfeiçoamento de Pessoal de Nível Superior (Capes) (cujo funcionamento será explicado nos capítulos 1 e 2). Desta maneira, 
o corpus ficou constituído por cinco periódicos científicos A2 (conforme descritos nos capítulos 1 e 2): E-Compós, Famecos, Galáxia, Intercom e MATRIZes.

Para realização deste trabalho, partimos de duas hipóteses, que serão discutidas nas considerações finais. Vamos a elas:

- Os periódicos científicos do corpus, por serem os mais bem classificados da área, conforme reconhecimento da Capes, por meio de representantes da própria área da Comunicação, têm alta exigência quanto à titulação de seus autores. Portanto, os pesquisadores serão, em sua maioria, doutores, e a maior parte dos trabalhos, escrita individualmente, como é tradição na área de Ciências Sociais e Humanas.

- A seleção de autores para publicação ainda privilegia o regional, principalmente nas revistas de programas de pós-graduação, que tendem a publicar autores da própria instituição de ensino ou pesquisa ou de instituições parceiras. Os motivos e consequências são discutidos no capítulo 5 .

\section{ESTRUTURA E METODOLOGIAS EMPREGADAS}

Consideramos que, para chegar ao objetivo do trabalho de definir o perfil predominante dos autores/pesquisadores brasileiros nos periódicos de Comunicação, é preciso localizar onde esse ator se insere dentro do campo da Comunicação e, por sua vez, (tentar) definir e explorar esse campo e revelar dentro dele o papel dos periódicos científicos.

Uma pesquisa sempre traz muito de subjetivo - de onde parte o autor do estudo, qual sua formação, em qual campo está inserido - e também é influenciada por fatores externos, inerentes ao próprio campo, como as universidades, instituições de pesquisa e fomento e agências reguladoras. Este trabalho, que discute o campo da Comunicação, sob o ponto de vista da sociologia da ciência, está nele inserido e sofre das mesmas pressões e influências que discutiremos nos capítulos 2 e 3. Portanto, ao debater o campo da Comunicação como sendo aquele que envolve o objeto teórico e o corpus desta pesquisa, a discussão também se aplica às condições desta própria investigação.

Acreditamos que, com base nesse preâmbulo, seja interessante apresentar aqui alguns fatores, que chamamos de subjetivos, a respeito da autoria desta pesquisa. A autora é jornalista pela Escola de Comunicações e Artes da Universidade de São Paulo, onde também realizou seu mestrado e conclui seu doutorado. O título de mestre foi obtido com a dissertação "Jornalistas como editores de livros", em Ciências da Comunicação, na área de Estudo dos Meios e da Produção Midiática. O doutorado está sendo concluído com esta tese na área de Teoria e Pesquisa em 
Comunicação, na linha Epistemologia, Teoria e Metodologia da Comunicação. Partimos portanto, de uma visão formada dentro das Ciências da Comunicação.

Sabemos a importância de manter a vigilância epistemológica (BOURDIEU, 1999: 23), que se impõe na separação entre a opinião comum e o discurso científico. E, conforme o próprio autor, é mais difícil, porém mais urgente, que a vigilância esteja presente com mais relevo quanto maior a familiaridade, por parte do pesquisador, com o universo social em que está incluso o objeto de estudo, já que essa situação constitui-se em um "obstáculo epistemológico por excelência". Manter a vigilância é um exercício difícil, porém este trabalho é, nesse sentido, tentativo.

A tese está dividida em cinco capítulos. O Capítulo 1 - Periódicos científicos traz uma definição dos periódicos, seu surgimento e representatividade na área de Ciências da Comunicação no Brasil. Já o Capítulo 2 - O editor científico e as demandas externas à edição aborda as condições em que são feitos os periódicos, o papel do editor científico e as pressões externas sofridas pelos periódicos em troca de reconhecimento institucional por parte de indexadores nacionais e internacionais, bem como de agências de fomento.

O Capítulo 3 - O perfil institucional das Ciências da Comunicação no Brasil trata da formação e reconhecimento do campo enquanto produtor de ensino e pesquisa, bem como o analisa tomando como base teórica a sociologia da ciência e as noções de campo e habitus de Bourdieu, na tentativa de realizar um retrato preparatório para o Capítulo 4 - Descrição e análise dos periódicos científicos em Comunicação. Este capítulo, por sua vez, delineia o corpus do estudo, apresenta os métodos de pesquisa e análise e os dados brutos obtidos.

Por último, o Capítulo 5 - Discussão - O autor brasileiro nos periódicos científicos - Quem são, temas e referências bibliográficas preponderantes, que traz as discussões dos dados, seus significados e resultados e se encerra com as considerações finais. 


\section{Capítulo 1}

\section{PERIÓDICOS CIENTÍFICOS}

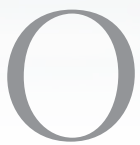

S PERIÓDICOS CIENTÍfICOS são um meio de comunicar o que há de mais recente sendo produzido pela ciência. Escrito, editado e lido pela comunidade científica de uma área específica, o periódico científico tem lugar determinante dentro do campo de estudos que abrange.

\subsection{O PERIÓDICO CIENTÍFICO E SEU LUGAR NA CIÊNCIA}

Ciência é conhecimento, informa a etimologia da palavra. E o conhecimento só faz sentido uma vez partilhado. É isso o que fazem os bons mestres, os bons professores e instrutores: partilham o conhecimento com aqueles que querem aprender.

Com a institucionalização da ciência - abertura das universidades, sociedades científicas e associações ainda na Idade Média -, surgiu naturalmente a necessidade de se compartilhar o conhecimento. A comunicação é "tão vital quanto a própria pesquisa, pois a esta não cabe reivindicar com legitimidade esse nome enquanto não houver sido analisada e aceita pelos pares. Isso exige, necessariamente, que seja comunicada" (MEADOWS, 1999: vii). Se um estudo é realizado, porém não partilhado e não lido, torna-se sem efeito, uma vez que permanece desconhecido de seus pares, daqueles que poderiam usar o conhecimento gerado e multiplicá-lo.

Há e houve diferentes maneiras de comunicar a ciência, como conferências, congressos, cartas, jornais impressos, revistas impressas e periódicos on-line, para citar apenas as formas de comunicação entre os próprios cientistas e os estudiosos da área. Além disso, a ciência e suas descobertas precisam ser mantidas para a posteridade - para que novas gerações desfrutem do conhecimento adquirido pelas antecedentes. 
Segundo Meadows, não é possível estabelecer quando se deu o início da pesquisa científica, nem o da comunicação dela. No entanto, "as atividades mais remotas que tiveram impacto na comunicação científica moderna foram inquestionavelmente as dos gregos antigos". Eles valiam-se das "mais importantes formas de comunicação, a fala e a escrita" (Ibid.: 3). As discussões filosóficas aconteciam nas Academias (locais na periferia de Atenas) e o conhecimento era registrado e recopiado diversas vezes em manuscritos.

O surgimento dos periódicos no século XVII atesta que a comunicação das descobertas científicas e estudos precisava ser ampliada e que os meios até então utilizados, como a correspondência em forma de cartas entre os cientistas e a publicação de livros, não eram mais suficientes para dar conta das transformações do mundo naquela época.

A correspondência pessoal foi o primeiro meio utilizado pelos cientistas para a transmissão de suas ideias. As cartas eram enviadas pelos homens de ciência a seus amigos para relatar suas descobertas mais recentes e circulavam entre pequenos grupos de interessados que as examinavam e discutiam criticamente. Sua divulgação era então direcionada, uma vez que seus autores quase nunca as enviavam para aqueles que podiam refutar suas teorias ou rejeitar seus experimentos (STUMPF, 1996).

O volume dessa correspondência logo passou a ser um ônus enorme: a solução cada vez mais óbvia seria fazer uma publicação impressa, com as cartas mais importantes, e distribuí-la (Meadows, 1999: 6).

O surgimento do periódico científico, ainda no século XVII, coincide com o incremento da ciência experimental, uma vez que os meios de comunicação até então utilizados com frequência pelos cientistas - a correspondência particular e a publicação ocasional de livros - mostram-se inadequados para a difusão das novas informações. Os livros têm como desvantagem a demora de edição... (FERREIRA \& TARGINO, 2005: 22).

As primeiras revistas científicas apareceram na Europa ainda no século XVII, com a criação das chamadas societés des savants (sociedades de sábios) (LEFEBVRE, 2008) e como consequência direta do crescimento e expansão das universidades. Na França, o Journal des Sçavans (depois renomeado Journal des Savants) foi criado em 1665 pela Academia de Ciências. Era semanal e divulgava catálogo de livros, notícias sobre descobertas nas ciências e artes, necrológios e outras informações afins. Em sua carta do "impressor ao leitor"1, o periódico

1. Disponível na Gallica - Bibliothèque Numérique, da Biblioteca Nacional da França http://gallica. bnf.fr/ark:/12148/bpt6k56523g/f3.image.langEN. Acesso em 21 abril 2013. 
esclarece a que veio: divulgação de livros, com comentários sobre eles, e das pesquisas em "Física e Química" que possam explicar os "efeitos da Natureza", notas sobre pessoas "célebres em suas doutrinas" que morram e sobre novas descobertas nas Artes e nas Ciências, como máquinas e invenções úteis ou curiosas, entre outras informações. Ou seja, um informativo voltado para o grupo de cientistas [seus pares, inseridos dentro de um determinado campo científico, considerando-se a definição de Bourdieu, que discutiremos no capítulo 3].

No Reino Unido, também no ano de 1665, surgiu o The Transactions of the Royal Society of London, de periodicidade anual. A literatura científica prefere considerá-lo como o primeiro periódico científico (e não o francês), pois “inaugurou o processo de avaliação dos textos a serem divulgados (peer review2)" (BARRADAS, 2005: 13). A publicação era ligada à Royal Society, patrocinada pelo rei Carlos II. Antes do periódico próprio, a Royal Society já se preocupava em comunicar seus estudos e, seus membros, em informarem-se sobre pesquisas e descobertas realizadas em outros países. A troca de informações era feita por meio de relatórios e cartas enviados por correio entre os membros. O interesse era apenas por estudos experimentais.

Em 1887, o periódico sofreu uma divisão e se tornou dois. Um, denominado Philosophical Transactions of the Royal Society A: Physical, Mathematical and Engineering Sciences, e o outro, Philosophical Transactions of the Royal Society B: Biological Sciences. E assim continuam a ser publicados atualmente ${ }^{3}$. Em 1684, também no Reino Unido, nasceu o News of the Republic of the Letters.

Historicamente ligada ao desenvolvimento da ciência, portanto, não causa estranhamento que no século XIX a produção das revistas científicas tenha crescido, acompanhando o aumento no número de pesquisadores e no interesse no tema da Ciência. "Além disso, os avanços técnicos de impressão e a fabricação do papel com polpa de madeira contribuíram para esta expansão" (STUMPF, 1996). Até o fim do século XIX, foram catalogadas 500 revistas científicas no mundo. Desde então, esse número só cresce. Em 2005, já eram 100 mil (FERREIRA \& TARGINO, 2005).

No século XX, o crescimento permaneceu "devido ao fato das revistas passarem a ser publicadas, também, por editores comerciais, pelo Estado e por universidades. A partir da segunda metade, especialmente, as publicações seriadas tiveram um crescimento exponencial" (DARNTON \& ROCHE, 1996: 285). E, sem dúvida, algumas das vantagens do periódico científico são sua agilidade de publicação - maior que a dos livros - e seu atestado de qualidade atribuído pela

2. Peer review $=$ revisão pelos pares.

3. http://rstl.royalsocietypublishing.org/. Acesso em agosto 2013. 
revisão por pares (peer review), o que por sua vez também gratifica os autores dos artigos, já que, ao serem publicados, são reconhecidos, por seus colegas, como vozes da ciência.

Dito isso, nota-se que o periódico, por um lado, surge de uma necessidade da ciência em comunicar seus resultados, estudos e descobertas e, por outro, ele contribui para a expansão desse conhecimento e amplitude da voz dos cientistas autores dos trabalhos.

[...] a história do periódico constata a sua relevância para a comunicação científica e, portanto, para o avanço da ciência e da tecnologia, a qual pauta a história da humanidade, ao favorecer tanto a divulgação de novos resultados como também o início de novas investigações (FERREIRA \& TARGINO, 2005: 22).

\subsection{DEFININDO OS PERIÓDICOS}

As primeiras revistas científicas já eram chamadas de periódicos por serem publicações seriadas, publicadas em intervalos fixos de tempo. O conceito de periódico, portanto, estabelece a marca do tempo (periodismo, período). O Instituto Brasileiro de Informação em Ciência e Tecnologia (Ibict) define periódico como uma

publicação seriada que se apresenta sob forma de revista, boletim, jornais etc; editada em fascículos com designação numérica e/ou cronológica, em intervalos pré-fixados (periodicidade), por tempo indeterminado, com a colaboração de diversas pessoas, tratando de assuntos diversos, dentro de uma política editorial definida (Ibict, s/d).

A Coordenação de Aperfeiçoamento de Pessoal de Nível Superior (Capes), agência de fomento à pesquisa de pós-graduação do Brasil, também tem sua própria definição para o que considera como periódico científico, e ela é adotada pela comissão da área de Ciências Sociais Aplicadas 1 (responsável pela qualificação e classificação dos periódicos científicos da área ${ }^{4}$ de Ciências da Comunicação). Essa definição estabelece que, para que um periódico seja classificado como científico, ele cumpra alguns critérios mínimos. Em linhas gerais, são eles: ter editor responsável, comissão editorial, conselho consultivo formado por pesquisadores de diferentes instituições, registro de International Standard

4. Neste trabalho, usamos de maneira distintas os termos área e campo. O primeiro, sempre que nos referimos às questões institucionais, como avaliações, delimitação de pesquisas, temas etc. Campo é usado segundo o conceito de campo científico de Bourdieu, a ser tratado no capítulo 3. 
Serial Number (ISSN), linha editorial definida, normas de submissão claras, periodicidade regular, avaliação dos originais por pareceristas, publicação de artigos assinados, indicação de titulação e afiliação institucional dos autores, título, resumo e palavras-chave dos trabalhos no mínimo em dois idiomas, data de recebimento de cada artigo e de sua aceitação para publicação ${ }^{5}$.

A comissão da área de Ciências Sociais Aplicadas 1, da Capes, além de aceitar a definição geral da agência de fomento, também diz que periódico cientifico é "uma publicação seriada, arbitrada e dirigida prioritariamente à comunidade acadêmico-científica” (conforme Documento de área 2013) ${ }^{6}$.

Em toda a bibliografia sobre o assunto periódico científico, há usos de diferentes terminologias, como revista científica e jornal científico. No entanto, a maior parte deste trabalho fará referência a ambos como "periódico científico", já que essa terminologia abrange todos os formatos e não se limita ao impresso.

De qualquer maneira, o periódico científico é, conforme Meadows (1999:7), uma "coletânea de artigos científicos escritos por diferentes autores. Conjuntos desses artigos são reunidos a intervalos, impressos, encadernados e distribuídos sob um único título". A definição de Meadows engloba exclusivamente os impressos, porém também se aplica (parcialmente) para os periódicos eletrônicos (on-line). Na nova mídia que é a eletrônica, a definição se mantém sobretudo quanto à referência "reunião de artigos de diversos autores reunidos a intervalos e distribuídos sob um único título" (Idem). Neste caso, no entanto, o leitor terá acesso ao periódico não em mãos, mas via um dispositivo eletrônico, seja ele o computador, celular ou outra plataforma de leitura com acesso à web. E não necessariamente o leitor fará uma leitura completa do periódico. Embora seja possível ler apenas um artigo de um periódico impresso, escolhido esse artigo no meio dos outros que compõem o mesmo volume e edição, no periódico on-line, o leitor pode ter acesso à leitura de um artigo fora do contexto geral da obra como foi pensada pelo editor. Isso porque é possível encontrar o artigo via buscador de internet ou até localizá-lo isoladamente nas plataformas de publicação dos periódicos on-line.

Sobre essa experiência de leitura que pode ser chamada de descontextualizada da obra integral de um periódico ou de um livro, Roger Chartier trata em A aventura do livro - do leitor ao navegador

5. Mais detalhes em http://www.capes.gov.br/images/stories/download/avaliacao/Comunicado_01_ 2013_Qualis_CSA.pdf. Acesso em agosto 2013.

6. Idem 
O fluxo sequencial do texto na tela, a continuidade que lhe é dada, o fato de que suas fronteiras não são mais tão radicalmente visíveis, como no livro que encerra, no interior de sua encadernação ou de sua capa, o texto que ele carrega, a possibilidade para o leitor de embaralhar, de entrecruzar, de reunir textos... (CHARTIER, 2009:13)

Além da maneira como define Meadows, é válido citar outro conceito para periódico científico, desta vez segundo Souza (1992: 81, apud Ohira, 2000: 2) e um tanto mais apropriada para o periódico on-line ${ }^{7}$ :

[...] publicações editadas em fascículos, com encadeamento numérico e cronológico, aparecendo a intervalos regulares ou irregulares, por um tempo indeterminado, trazendo a colaboração de vários autores, sob a direção de uma ou mais pessoas, mas geralmente de uma entidade responsável, tratando de assuntos diversos, porém dentro dos limites de um esquema mais ou menos definido.

Portanto, fica claro que "o uso principal do termo está associado a publicações periódicas impressas em formato tablóide, embora, também, possa referir-se à versão on-line e a títulos encontrados exclusivamente na Internet" (FORTES, 2010: 1.083).

\subsection{O NASCIMENTO DOS PERIÓDICOS CIENTÍFICOS DE CIÊNCIAS DA COMUNICAÇÃO NO BRASIL}

Assim como os estudos no campo da Comunicação no Brasil são recentes -começam na década de 1950 (LOPES, 2005: 52), com pesquisas funcionalistas baseadas em métodos quantitativos (de conteúdo, de audiência e de efeitos) -, os periódicos científicos dedicados exclusivamente aos estudos do campo também são jovens.

A revista científica pioneira da área de Comunicação no Brasil foi Comunicações $\&$ Problemas, cuja primeira edição data de abril de 1965. Lançada pelo professor e pesquisador Luiz Beltrão na Universidade Católica de Pernambuco, foi transferida depois para Brasília. Foi inspirada na revista norte-americana Journalism Quaterly, tinha periodicidade quadrimestral e durou 12 números, até 1969 (MELO, 2005: 17-18). A Journalism Quaterly, por sua vez, é a primeira revista científica (SOUZA,

7. Livro esgotado - SOUZA, Denise H. Farias de. Publicações periódicas: processos técnicos, circulação e disseminação seletiva da informação. Belém: Editora UFPA, 1992. 229 p., p. 17-42 
2003) da área de Comunicação, lançada em 1924 nos Estados Unidos, e que se tornou, em 1996, a Journalism \& Mass Communication Quaterly.

Posteriormente, em 1978, foi lançado o Boletim Intercom, que se tornou, em 1984, a Revista Brasileira de Estudos Interdisciplinares da Comunicação - conhecida como Revista da Intercom. O boletim não continha apenas conteúdo científico, já que também era usado como meio de divulgação de eventos e informações institucionais da Intercom. Em 1979, foi lançada a revista científica Comunicação e Sociedade, da Universidade Metodista de São Paulo. Naturalmente, essas publicações pioneiras eram, a princípio, disponíveis apenas em versão impressa. A Revista Intercom ganhou sua versão on-line em 2006 e a Comunicação e Sociedade, em 1999.

É interessante notar que na origem das revistas científicas de Comunicação do país estão universidades (e, logo, professores e pesquisadores universitários), mas também uma associação de pesquisadores, a Sociedade Brasileira de Estudos Interdisciplinares da Comunicação (Intercom), que agrega estudiosos de diversas instituições de ensino.

Em Ciências da Comunicação, além dos pioneiros já citados e dos quais dois continuam a ser editados (a Revista Brasileira de Estudos Interdisciplinares da Comunicação e a Comunicação e Sociedade), surgiram muitos outros periódicos no Brasil. A quantificação total dos periódicos científicos nacionais da área é difícil de precisar. No entanto, entre os reconhecidos pela Capes, órgão ligado ao Ministério da Educação e Cultura, classificados na área de Ciências Sociais Aplicadas 1, especificamente os de Comunicação são 101 - contando apenas uma das versões (on-line ou impressa) ${ }^{8}$.

Ainda dentro de Ciências Sociais Aplicadas 1 estão os periódicos de Ciências da Informação e Museologia. Assim, podemos considerar 1.233 periódicos científicos reconhecidos e classificados pelo WebQualis, da Capes, nessa área. A apuração dos títulos dos periódicos e a análise deles são feitas a partir de sua citação no currículo Lattes dos pesquisadores da área em questão. Ou seja, se ao menos um pesquisador das Ciências da Comunicação tiver publicado um artigo em um determinado periódico científico no ano anterior (ou durante o triênio) estudado, essa publicação será incluída e analisada. Isso quer dizer que a área da Comunicação pode ter mais periódicos científicos, porém estamos considerando aqui apenas os relacionados pelo WebQualis da Capes.

A Capes é o órgão responsável pela avaliação dos programas de pós-graduação stricto sensu, pelo acesso e divulgação da produção científica brasileiros, pelos

8. WebQualis 2013. 
investimentos na formação de recursos de alto nível no Brasil e no exterior e por promover a cooperação internacional entre pesquisadores, entre outras atribuições ${ }^{9}$. Já o WebQualis é um

Conjunto de procedimentos utilizados pela Capes para estratificação da qualidade da produção intelectual dos programas de pós-graduação... Como resultado, disponibiliza uma lista com a classificação dos veículos utilizados pelos programas de pós-graduação para a divulgação de sua produção. A estratificação da qualidade dessa produção é realizada de forma indireta. Dessa forma, o Qualis afere a qualidade dos artigos e de outros tipos de produção, a partir da análise da qualidade dos veículos de divulgação, ou seja, periódicos científicos (Site Capes, s/d) ${ }^{10}$.

Dessa maneira, é relevante destacar que o WebQualis, embora não seja per se um sistema de análise de periódicos científicos, acaba por desenvolver esse papel desde o triênio 2008-2011, quando foi lançado (como Qualis - o Web foi recebido quando passou a ser publicado on-line). Embora o objetivo seja classificar a produção dos programas de pós-graduação por meio da publicação de artigos e do nível das revistas em que estes são publicados, indiretamente acaba sendo uma referência para a classificação de revistas, uma vez que, na prática, classifica os periódicos e os agrupa em diferentes extratos de acordo com exigências específicas para cada um deles.

Além da Capes, diversas outras instituições nacionais, regionais e internacionais realizam programas de avaliação de revistas com metodologias próprias desde a década de 1960, como a Organização das Nações Unidas para Educação, Ciências e Cultura (Unesco), o Centro Latino-Americano e do Caribe de Informação em Ciências da Saúde (Bireme), apenas para citar alguns (STUMPF, 2003: 27).

Voltando à avaliação WebQualis Capes, sistema escolhido como a base para eleição do corpus deste trabalho, está estabelecido, para a coordenação da área de Ciências Sociais Aplicadas 1, que, para que um periódico seja classificado como científico, é preciso cumprir alguns critérios mínimos, que valem ser descritos. Em linhas gerais, são eles: ter editor responsável, comissão editorial, conselho consultivo formado por pesquisadores de diferentes instituições, registro de ISSN ${ }^{11}$,

9. Disponível em http://www.capes.gov.br/sobre-a-capes/historia-e-missao. Acesso em agosto 2013. 10. Disponível em http://www.capes.gov.br/avaliacao/qualis. Acesso em agosto 2013.

11. ISSN é um código numérico que constitui um identificador para cada título de publicação em série e é é definido pela norma ISO 3297:2007 - Information and Documentation. International Standard Serial Number ISSN. A Rede ISSN foi criada com apoio da Unesco em 1971 e, no Brasil, o Ibict desenvolve as funções nacionais da Rede. http://www.ibict.br/informacao-para-ciencia-tecnologia-e-inovacao\%20/ centro-brasileiro-do-issn. Acesso em março 2015. 
linha editorial definida e normas de submissão claras, periodicidade regular, realizar avaliação dos originais por pareceristas, publicar artigos assinados, e indicar titulação e afiliação institucional dos autores, título, resumo e palavras-chave no mínimo em dois idiomas, data de recebimento de cada artigo e aceitação para publicação ${ }^{12}$.

Como dito anteriormente, as Ciências da Comunicação possuem 101 periódicos científicos nacionais classificados no WebQualis 2010-2012, o triênio mais recente, nos estratos indicativos de qualidade entre $\mathrm{A}_{2}$ e $\mathrm{B}_{5}$. Na área $\mathrm{A}_{1}$, estrato considerado de nível e alcance internacional, não há revistas de Comunicação nacionais. Portanto, os periódicos científicos brasileiros mais bem classificados da área estão em A2 e são os seguintes ${ }^{13}$ :

- E-Compós (da Associação Nacional dos Programas de Pós-Graduação em Comunicação, quadrimestral, apenas on-line);

- Famecos (da Faculdade de Comunicação Social da Pontifícia Universidade Católica do Rio Grande do Sul, quadrimestral, on-line);

- Galáxia (do Programa de Pós-Graduação em Comunicação e Semiótica da Pontífícia Universidade Católica de São Paulo, semestral, on-line e impressa);

- Intercom (da Sociedade Brasileira de Estudos Interdisciplinares da Comunicação, semestral, on-line e impressa);

- MATRIZes (do Programa de Pós-Graduação em Ciências da Comunicação da USP, semestral, on-line e impressa).

Os demais periódicos da área de Comunicação ${ }^{14}$ estão assim classificados ${ }^{15}$ :

Tabela 1 - NÚMERO DE PERIÓDICOS DE CIÊNCIAS DA COMUNICAÇÃO ENTRE OS ESTRATOS B1 E B5

\begin{tabular}{|c|c|}
\hline Estrato & Quantidade de periódicos \\
\hline B1 & 32 \\
\hline B2 & 10 \\
\hline B3 & 15 \\
\hline B4 & 20 \\
\hline B5 & 19 \\
\hline
\end{tabular}

Fonte: Avaliação 2012 WebQualis

12. Mais detalhes em http://www.capes.gov.br/images/stories/download/avaliacao/Comunicado_01_ 2013_Qualis_CSA.pdf. Acesso em agosto 2013.

13. São esses cinco periódicos que constituem o corpus de pesquisa deste trabalho.

14. Anexo 1

15. Não foram considerados os periódicos classificados como C, pois esse estrato é dedicado aos não científicos. 
Para serem classificados em cada um dos estratos, os periódicos científicos devem obedecer a certos critérios de qualidade. $\mathrm{Na}$ área $\mathrm{A} 1$, na qual não há nenhum periódico científico nacional de Comunicação, como observado anteriormente, estão "classificados os periódicos científicos indexados na Web of Science ${ }^{16}$ e/ou JCR (Journal Citation Reports) Social Sciences, relacionado à área de Ciências Sociais Aplicadas 1 e à área de conhecimento Ciências Humanas", conforme documento de área CSA citado acima.. É possível explicar essa única exigência para esse estrato: para ser indexado no Web of Science, é preciso que a revista tenha uma série de procedimentos de qualidade na edição e ainda seja citada por pesquisadores em artigos presentes nessa mesma base de dados. O JCR ${ }^{17}$, por sua vez, faz uma análise quantitativa e estatística de citações de artigos dos periódicos

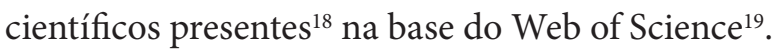

No estrato A2, é exigido que o periódico esteja (A) indexado na base Scopus e/ou Scielo (caso da Revista Intercom). E foram considerados outros requisitos, listados a seguir:

B) Origem da publicação - periódico publicado por instituição com PósGraduação stricto sensu, ou Sociedade Científica de âmbito nacional ou internacional, ou Instituição de Pesquisa, ou publicada com apoio da Capes, CNPq ou financiada por órgão de fomento de âmbito estadual.

C) Origem dos artigos - conter artigos de autores doutores, vinculados a diferentes instituições, com expressiva publicação de artigos, por volume, de autores ou coautores filiados a instituições estrangeiras.

D) Reputação do periódico - periódicos identificados como relevantes para a área, de acordo com os seguintes critérios: origem da publicação, origem dos artigos, quantidade de artigos no triênio 2007-2009 e nos anos de 2010 e 2011, acessibilidade facilitada pelo formato digital, projeção internacional do periódico indicada por publicação de artigos e autores estrangeiros.

E) Classificação especial - com a inclusão do critério Reputação, foi selecionado e analisado, individualmente, um grupo de periódicos da área da Comunicação com maior número de artigos no triênio 2007-2009, em 2010 e em 2011, classificados como B1 e passíveis de análise visando o Estrato A2. Foram quatro periódicos nesse caso: Galáxia, MATRIZes e Revista Famecos, que responderam aos critérios $\mathrm{B}, \mathrm{C}, \mathrm{D}$ e E, e a revista E-Compós que respondeu aos critérios $\mathrm{B}, \mathrm{C}$ e $\mathrm{D}^{20}$.

16. Será explicado no capítulo 2.

17. Disponível em http://wokinfo.com/products_tools/analytical/jcr/. Acesso em agosto 2013.

18. Disponível em http://ip-science.thomsonreuters.com/mjl/. Acesso em agosto 2012.

19. Disponível em http://thomsonreuters.com/web-of-science/. Acesso em agosto 2012.

20. Mais detalhes em http://www.capes.gov.br/images/stories/download/avaliacao/Comunicado_ 01_2013_Qualis_CSA.pdf. Acesso em agosto 2012. 
No caso específico da E-Compós, o documento salienta que a "Comissão decidiu pela sua inclusão nesse estrato por ter sido escolhido pelos programas e pesquisadores da Área, em 2011, para receber investimentos da Capes destinados à sua inserção internacional".

Como detalhado acima, por conta desses critérios incluírem a necessidade de os periódicos estarem presentes em indexadores e bancos de dados, os periódicos acabam obedecendo a regras de edição determinadas externamente ao seu corpo editorial e científico. Ou seja, no caso de A2, a Revista da Intercom se classifica por estar indexada no Scielo (Scientific Electronic Library Online), coleção nacional de artigos e periódicos científicos, que inicialmente era voltada apenas para as Ciências da Saúde, porém hoje abrange todas os campos do conhecimento. Para ser indexado no Scielo, o periódico deve seguir critérios determinados de qualidade exigidos por ele. $\mathrm{O}$ mesmo acontece com outros indexadores, como Redalyc $^{21}$ (Red de Revistas Científicas de América Latina y Caribe, España y Portugal), Scopus 22 (banco de dados de citações) e Web of Science.

As exigências e pressões sofridas pelo editor científico serão discutidas com mais profundidade no próximo capítulo.

21. Disponível em http://www.redalyc.org. Acesso em agosto 2013.

22. Disponível em http://www.scopus.com/home.url. Acesso em agosto 2013. 


\section{Capitulo 2}

\section{O EDITOR CIENTÍFICO E AS DEMANDAS EXTERNAS À EDIÇÃO}

$\mathrm{P}$

OR TRÁS DOS periódicos científicos apresentados como um produto final aos leitores (também cientistas ou interessados em um campo científico específico) foram muitas as escolhas feitas. O conjunto dessas escolhas pode ser chamado de edição. A palavra editar vem do latim edo, editum, edere, que significa dar a lume, dar à luz, publicar. O termo editor surge "na Roma antiga para identificar aqueles que chamavam a si a responsabilidade de multiplicar e cuidar das cópias dos manuscritos originais dos autores, zelando para que fosse correta a sua reprodução" (BRAGANÇA, 2001: 18). Da mesma maneira, o editor científico tem o papel de trazer à luz o que ele considera o melhor da produção científica dentro de um escopo predeterminado de exigências de sua revista. Ao editor científico cabe selecionar, com a ajuda de pareceristas da área, os artigos que considera como sendo aqueles que devem ganhar visibilidade por meio de sua revista. É verdade ainda que ele deve contar, para uma escolha justa e bem embasada, com a análise de pareceristas da área - cientistas, colegas que estudam o assunto abordado no texto em questão - que emitem sua opinião (um parecer) sobre a adequação daquele artigo em ser publicado no periódico; analisando, entre outros aspectos, se ele é bem fundamentado teoricamente, inovador ou portador de alguma contribuição para aquele campo científico naquele momento.

Os periódicos científicos possuem cada um suas especificidades, determinadas por seus comitês científicos ou editoriais, e é papel do editor zelar para que elas sejam cumpridas. Entre outros aspectos a serem considerados, podem ser eles o grau acadêmico dos autores (apenas doutores, por exemplo); subtemas específicos para uma edição; especificações de formato, como tamanhos mínimo e máximo de 
um artigo, padrões de citação, resumo e palavras-chave em dois ou mais idiomas. Além disso, um periódico científico é sempre formado por um comitê ou comissão editorial e um comitê científico, embora cada periódico tenha sua equipe e subdivisões em sua gestão editorial. De forma geral, especialmente nas revistas de Comunicação e especificamente nas revistas que formam o corpus deste trabalho (Revista E-Compós, Famecos, Galáxia, Revista da Intercom e MATRIZes), o comitê editorial cuida do dia a dia da publicação (sempre encabeçada por um editor, embora este nem sempre esteja em destaque no expediente do periódico), e o científico, atua como uma equipe de consultoria e é formado por pessoas de renome na área acadêmica e científica em questão. O documento de área da Comissão de Ciências Sociais Aplicadas 1, da Capes, exige que os periódicos científicos tenham um editor responsável e uma comissão editorial que auxilie o editor na tomada de decisões.

O editor de um periódico, portanto, é o principal responsável pela publicação e cerca-se de seus pares e normas predeterminadas para basear suas escolhas.

\subsection{O EDITOR CIENTÍFICO E O NASCIMENTO DE UM PERIÓDICO}

"Muitas vezes sente-se com responsabilidades políticas diante de sua sociedade, talvez nesta função-tipo se acentue o seu eros pedagógico" (BRAGANÇA, 2001: 126,127). Bragança trata nesse trecho sobre o sentimento de obrigação política e social do editor de livros. No entanto, a "paixão pedagógica" é geralmente a primeira motivação também de um editor científico que vê em seu periódico um divulgador e propagador dos estudos relacionados a seu campo. No caso das revistas de Comunicação, mais especificamente das revistas que compõem o corpus deste estudo, os editores responsáveis pelas publicações são professores da área, que se dedicam à edição do periódico enquanto atividade extra não remunerada, paralela à sua função como docente e pesquisador. Da mesma forma trabalham os membros do comitê científico e editorial, bem como os pareceristas ad-hoc. ${ }^{23}$

Ao fazer escolhas, o editor tem a função de gatekeeper, termo usado no jornalismo e também por THOMPSON (2005: 1999), ao mencionar professores que indicam livros e bibliografia a alunos. Da mesma maneira, o editor do periódico científico funciona como gatekeeper do que será publicado em seu periódico, divulgando ou não certos autores, teorias e linhas de pensamento. Essa vocação de divulgar os estudos do campo e seu respectivo enriquecimento cultural, científico e teórico aparece no texto que define a missão em dois dos cinco periódicos do corpus deste trabalho.

23. Expressão latina que significa "para isso", "com essa finalidade”. São pesquisadores da área que não pertencem ao corpo fixo da revista, mas atuam como colaboradores para emitir parecer. 
Para a Revista da Intercom, sua missão é "contribuir para a difusão do conhecimento científico e a reflexão pluralista sobre Comunicação"24. Para a Revista Famecos, é "publicar importantes autores internacionais da área, bem como acolher os principais pesquisadores brasileiros e explorar os temas mais relevantes da comunicação"25.

O patrocínio de periódicos científicos é bastante restrito a algumas poucas fontes, como agências de fomento governamental (federal - Capes, CNPq; Fapesp, Fapemig e outras agências estaduais) e programas internos de apoio a publicações (como o SIBI-USP - Sistema Integrado de Bibliotecas da Universidade de São Paulo - exclusivo a revistas dessa instituição). Boa parte das revistas é mantida financeiramente por suas próprias instituições de origem, sejam elas programas de pós-graduação ou associações da área.

Todos os apoios públicos citados anteriormente direcionam verbas às publicações via lançamento de edital, cuja seleção é baseada em critérios próprios. Em comum, de maneira geral, destacam-se a exigência de que os periódicos impressos tenham também suas versões eletrônicas e que ofereçam acesso aberto ${ }^{26} \mathrm{e}$ irrestrito a todo o seu conteúdo, já que trata-se de verba pública. Essa exigência também é comum a indexadores nacionais e internacionais, como se verá adiante. No caso das Ciências da Comunicação, os periódicos do corpus ${ }^{27}$ utilizam-se do sistema Seer/OJS, uma plataforma de acesso aberto (open source), gratuita, que permite a troca de artigos com outros portais construídos sobre a mesma base tecnológica. Desenvolvido e lançado em 2001 pela Universidade British Columbia sob a denominação OJS (open jornal systems), foi traduzido e customizado no Brasil pelo Ibict e recebeu o nome de Seer (sistema eletrônico de editoração de revistas) ${ }^{28}$. Além de ser um sistema publicador, a ferramenta é capaz de fazer toda a gestão editorial da revista, com funcionalidades de receber artigos, enviar respostas aos autores, mandar artigos para pareceristas entre outras atividades do fluxo editorial.

24. http://www.portalintercom.org.br/index.php?option=com_content\&view=article\&id=344\&Item id=104. Acesso em março 2015.

25.http://revistaseletronicas.pucrs.br/ojs/index.php/revistafamecos/about/editorialPolicies\#focusAn dScope. Acesso em março 2015.

26. Em 2008, o Instituto de Artes e Ciências da Universidade de Harvard, juntamente à biblioteca da instituição, iniciou um projeto para disponibilizar livre e gratuitamente artigos até então de acesso fechado, em sua maioria pagos, produzidos pelos docentes e pesquisadores do Instituto. Paralelamente, a biblioteca criou um repositório digital para armazenar e disponibilizar essa produção. Sobre esse assunto, consultar Darnton, 2010.

27. Conforme Tabela 2.

28. http://seer.ibict.br/index.php?option=com_content\&task=view\&id=286\&Itemid=74. Acesso em março 2015. 
Até o presente momento, ano de 2015, são poucas as publicações científicas que se utilizam dos recursos interativos, de vídeo, áudio e hiperlinks oferecidos pela web. Nenhuma das cinco publicações discutidas aqui vão além da transposição do conteúdo impresso para o meio digital, utilizando arquivos em PDF (portable document format) para a publicação de suas versões eletrônicas e o formato HTML (hyper text mark-up language), também oferecido pelo publicador Seer. Nem mesmo publicações exclusivamente on-line, como a E-Compós, publicam seus artigos em formato diferente.

Em artigo baseado em sua tese de doutorado e publicado no ano de 1998, Targino já previa a coexistência das publicações impressas e eletrônicas, bem como que estas últimas seriam apenas réplicas das primeiras. "Há uma crença de uma "coexistência pacífica" entre periódicos científicos impressos e eletrônicos, pelo menos por algum tempo (grifo nosso), com a prevalência de réplicas eletrônicas das versões impressas" (TARGINO, 1998: 72). A “crença” citada no artigo, de 1998, ainda é realidade em 2015.

Tabela 2 - ALGUMAS INFORMAÇÕES SOBRE OS PERIÓDICOS NACIONAIS ESTRATO WEBQUALIS A2 ${ }^{29}$

\begin{tabular}{|c|c|c|c|c|c|}
\hline $\begin{array}{l}\text { Extratos } \\
\text { do roteiro }\end{array}$ & E-Compós & Famecos & Galáxia & Intercom & MATRIZes \\
\hline $\begin{array}{l}\text { Conselho } \\
\text { editorial }\end{array}$ & $\begin{array}{c}49 \text { brasileiros } \\
\text { e } 10 \\
\text { estrangeiros }\end{array}$ & $\begin{array}{c}19 \text { brasileiros e } 9 \\
\text { estrangeiros }\end{array}$ & $\begin{array}{c}33 \text { brasileiros } \\
\text { e } 3 \\
\text { estrangeiros }\end{array}$ & $\begin{array}{l}65 \text { brasileiros e } \\
28 \text { estrangeiros }\end{array}$ & $\begin{array}{l}27 \text { brasileiros e } \\
16 \text { estrangeiros }\end{array}$ \\
\hline $\begin{array}{l}\text { Parcerias, } \\
\text { fomento ou } \\
\text { patrocínio }\end{array}$ & $\begin{array}{l}\text { Associação } \\
\text { Nacional dos } \\
\text { Programas } \\
\text { de Pós- } \\
\text { graduação em } \\
\text { Comunicação }\end{array}$ & $\begin{array}{l}\text { Patrocínio Ibict e } \\
\text { Supernova Editora. } \\
\text { Editora Edipucrs }\end{array}$ & $\mathrm{CNPq}$ & $\begin{array}{c}\text { CNPq, Intercom } \\
\text { e Capes }\end{array}$ & SIBI-USP \\
\hline Periodicidade & Quadrimestral & Quadrimestral & Semestral & Semestral & Semestral \\
\hline $\begin{array}{l}\text { Perfil de } \\
\text { autores }\end{array}$ & $\begin{array}{l}\text { Mínimo } \\
\text { doutorando }\end{array}$ & $\begin{array}{l}\text { Doutores (artigos) e } \\
\text { mestre para resenha }\end{array}$ & $\begin{array}{c}\text { Mínimo } \\
\text { doutorando }\end{array}$ & Não especifica & $\begin{array}{c}\text { Mínimo } \\
\text { doutorando }\end{array}$ \\
\hline $\begin{array}{l}\text { Modo de } \\
\text { submissão }\end{array}$ & $\begin{array}{c}\text { Sistema Seer/ } \\
\text { OJS }\end{array}$ & Sistema Seer/OJS & $\begin{array}{c}\text { Sistema Seer/ } \\
\text { OJS }\end{array}$ & $\begin{array}{c}\text { Sistema Seer/ } \\
\text { OJS }\end{array}$ & $\begin{array}{c}\text { Sistema Seer/ } \\
\text { OJS }\end{array}$ \\
\hline $\begin{array}{l}\text { Identificaccão } \\
\text { do periódico }\end{array}$ & Nome, E-ISSN & Nome, E-ISSN & $\begin{array}{l}\text { Nome, } \\
\text { E-ISSN }\end{array}$ & $\begin{array}{c}\text { Nome, ISSN e } \\
\text { E-ISSN }\end{array}$ & Nome, E-ISSN \\
\hline $\begin{array}{l}\text { Presença } \\
\text { em base de } \\
\text { dados }\end{array}$ & $\begin{array}{c}\text { Portal Capes e } \\
\text { Latindex }\end{array}$ & $\begin{array}{c}\text { Clase, Doaj, IAI, } \\
\text { Latindex, CNEN/ } \\
\text { LivRe, OJS, Portal } \\
\text { Capes, Revcom, } \\
\text { Red lberoamericana } \\
\text { de revistas de } \\
\text { comunicación y } \\
\text { cultura, Seer-lbict, } \\
\text { Sumários.org., } \\
\text { Univerciencia }\end{array}$ & Não cita & $\begin{array}{c}\text { Scielo, DOAJ, } \\
\text { Latindex, Public } \\
\text { Knowledge } \\
\text { Project, } \\
\text { Institutional } \\
\text { Archieves } \\
\text { Registry, Revcom }\end{array}$ & $\begin{array}{c}\text { DOAJ, CMMC, } \\
\text { Redalyc, } \\
\text { Latindex, } \\
\text { Portal de la } \\
\text { Comunicación, } \\
\text { OEI, Ibict, } \\
\text { Univerciencia, } \\
\text { WZB, Portal de } \\
\text { Revistas USP } \\
\text { (Sibi) }\end{array}$ \\
\hline
\end{tabular}

29. Análise com base em resumo de roteiro desenvolvido por GRUSZYNSKI, GOLIN e CASTEDO (2008) para edição de periódicos científicos. As informações foram retiradas a partir das versões on-line dos periódicos científicos em agosto de 2013. 
Capitulo 2 - O editor científico e as demandas externas à edição

\subsection{DEMANDAS EXTERNAS E INDEXADORES}

Como visto no capítulo 1, o WebQualis lista uma série de quesitos para que os periódicos científicos sejam classificados e essa exigência é tanto maior quanto mais bem posicionado for o estrato. Assim, conforme cada estrato, é exigido que os periódicos estejam presentes em determinados indexadores e bases de dados e isso, naturalmente, acarreta outra série de especificações e normas que as revistas devem seguir, posto que cada indexador tem suas próprias exigências. Embora muitas vezes se usem na literatura sobre periódicos científicos os termos base de dados e indexadores como sinônimos, é importante ressaltar que todo indexador possui sua base de dados, formada por periódicos que passam por uma certificação de mérito segundo normas e pré-requisitos estabelecidos por cada um dos indexadores. Uma vez aprovado, o periódico passa a ser parte da base de dados do indexador. No entanto, há bases de dados que funcionam como uma coleção de revistas, sem submeter o periódico a uma avaliação para incluí-lo em sua coleção, exemplo do Índice de Revistas da OEI (Organización de Estados Iberoamericanos), que reúne publicações dos países que fazem parte da rede. Para o estrato A2, que nos interessa em particular, é pedido, em primeiro lugar, que o periódico esteja indexado na Scielo (Scientific Electronic Library Online), como visto anteriormente.

\subsubsection{Scielo e Scopus}

Em 1982, a Bireme (Centro Latino Americano e do Caribe de Informação em Ciências da Saúde) lança a Lilacs (Literatura latino-americana e do Caribe em Ciências da Saúde), base de dados criada para indexar periódicos e outros documentos da área de Ciências da Saúde, a exemplo de outros indexadores de outras regiões do mundo, como o Medline, entre outros. O objetivo era promover e registrar a literatura científica dessa área de conhecimento produzida na América Latina e no Caribe (CASTRO, FERREIRA \& VIDILI, 1996), com diferentes bases nos países componentes, que receberam a responsabilidade de incluir a produção local, escolhida com critérios mais técnicos-normativos. A grande novidade, na época, era o fato de ser uma avaliação para indexação e não financiamento, como os demais existentes até então, como Capes, CNPq e outras agências de fomento (TRZESNIAK, 2006: 347). Em 1996, a Bireme se une à Fapesp para criar a Scielo (e ganham a parceria do CNPq em 2002), esta sim um indexador seletivo, com escolhas de periódicos e documentos após avaliação de especialistas da área, além da exigência em relação a aspectos técnicos e normativos. Sua operação teve início efetivamente em $1998 .^{30}$

30. Sobre a história da Scielo, consultar o livro eletrônico Scielo - 15 anos de acesso aberto: um estudo 
Por ser a seleção de periódicos feita pela Scielo de reconhecida exigência, o WebQualis considera que todo periódico que esteja nessa coleção já possa automaticamente receber o status de A2, caso da Revista da Intercom, admitida na coleção em junho de $2012^{31}$. O comitê consultivo da Scielo Brasil se reúne no mínimo três vezes ao ano e é formado por representantes de cada grande área (Ciências Agrárias, Biológicas, Exatas, Humanas e Letras, Linguística e Artes), um representante da Associação Brasileira de Editores Científicos (Abec), da Fapesp, do CNPq, da Capes, além do diretor do Programa Scielo/Fapesp - que atua como coordenador do Comitê Consultivo. Para que o periódico seja analisado por esse comitê, é preciso que a equipe editorial envie alguns documentos, como carta de apresentação e um formulário que exige uma série de informações, algumas das quais destacamos a seguir.

- bases de dados nacionais e internacionais nas quais o periódico por ventura esteja inscrito;

- fluxo de publicação - quantos artigos recebidos, aprovados, rejeitados e publicados;

- se o periódico é financiado pelo CNPq e qual sua classificação Qualis;

- a classificação Capes recebida pelo programa de pós-graduação ao qual o periódico está ligado (se for o caso);

- seguir periodicidade mínima semestral para periódicos da área de Ciências Humanas, incluindo Social Aplicadas (dado válido até 2013; em 2014 passou a ser quadrimestral) e mínimo de 12 artigos originais por edição (passou a ser de 25 ) $^{32}$

- apresentação do modelo de ficha enviada para que pareceristas realizem a avaliação dos artigos.

Além da Scielo, que ganhou renome na área de saúde e depois ampliou sua abrangência, a Scopus também é um indexador multidisciplinar considerado pela área de Ciências Sociais Aplicadas 1 para classificar os periódicos ali inseridos como sendo A2. No caso das Ciências da Comunicação, não há nenhum periódico brasileiro indexado. A Scopus foi criada em 2004 pela Editora Elsevier e juntamente com o Google Scholar e a Web of Science são as "três maiores bases de dados multidisciplinares" (explicado mais adiante neste capítulo). (JACSO, 2005: 1538).

A tabela 3, a seguir, mostra os indexadores exigidos para cada estrato na subárea de Comunicação.

analítico sobre acesso aberto e comunicação científica. Editora Unesco, 2014 . DOI: http://dx.doi.org/ $10.7476 / 9789237012376$.

31. Embora fora do período de abrangência deste trabalho, concentrado entre os anos 2000 e 2012, é importante atualizar que a revista Galáxia também entrou para a coleção em Scielo em março de 2014. 32. Os novos critérios estão publicados em http://www.scielo.br/avaliacao/20141003NovosCriterio s_SciELO_Brasil.pdf. Acesso em dezembro 2014. 
Capitulo 2 - O editor científico e as demandas externas à edição

Tabela 3 - INDEXADORES EXIGIDOS POR ESTRATO EM WEBQUALIS

\begin{tabular}{|c|c|}
\hline Estrato & Indexadores e bases de dados \\
\hline A1 & Web of Science e/ou JCR \\
\hline A2 & Scopus e/ou Scielo \\
\hline B1 & $\begin{array}{c}\text { Ao menos uma das seguintes bases: Latindex, Redalyc, Doai } \\
\text { (para periódicos eletrônicos), Clacso, Clase }\end{array}$ \\
\hline B2 & Doaj \\
\hline B3, B4, B5 & Não há exigência em relação a indexadores \\
\hline
\end{tabular}

\subsubsection{Web of Science e JCR}

Pela ordem dos estratos, é possível perceber que o comitê de área de Ciências Sociais Aplicadas 1 exige indexadores e, por sua vez, também os classifica como sendo de maior ou menor exigência. Em A1, estrato no qual não está nenhuma revista brasileira de Ciências da Comunicação, exige-se a presença no Web of Science e/ou JCR, da editora Thomson Reuters. O Web of Science é uma plataforma que, ao mesmo tempo que permite o acesso integrado a bases de dados consideradas de grande importância, como a própria Scielo Citation Index e a Medline (base de dados bibliográfica do U.S. National Library of Medicine), entre outras, também reúne sua própria coleção de periódicos, a Web of Science Core Collection, que tem critérios próprios de seleção de periódicos. O JCR (Journal of Citation Report) é um recurso dentro do próprio Web of Science, que avalia os periódicos presentes nessa base de dados, por meio de índices bibliométricos, $o$ que permite o cálculo do fator de impacto dos periódicos, que por sua vez, reflete o número médio de citações de artigos de artigos científicos publicados em um determinado periódico. Anualmente, o JCR publica a lista dos periódicos mais citados em uma determinada área, apontando a importância da publicação para a comunidade científica.

Os demais indexadores e bases de dados mais relevantes para a área de Comunicação estão contemplados nos estratos apresentados na tabela 3.

\subsubsection{Google Scholar}

Em 2004, foi lançado o Google Scholar (em português, Google Acadêmico), um motor de busca especializado em conteúdos acadêmicos, recorrendo a uma adaptação do famoso algoritmo do Google de procura na internet, mas em que agora a ordenação dos resultados da busca se baseia no número de citações da publicação, uma forma alternativa de medir "recomendações", 
em vez da estrutura das hiperligações que apontam para um dado site na internet (BEIRA, 2010: 132).

A Google deu um passo além em 2012, quando lançou o Google Scholar Metrics, "um novo sistema de avaliação bibliométrica das revistas científicas a partir do número de citações que essas receberam no Google Scholar" (DELGADO \& REPISO, 2013: 46). Embora não esteja contemplado como exigência em nenhum estrato WebQualis da área de Ciências Sociais Aplicadas 1, a área de Comunicação aponta para a necessidade de uma observação mais próxima sobre ele. Alguns trabalhos recentes, citados a seguir, já apontam que o Google Scholar prenuncia-se como uma ferramenta talvez (mais) adequada para avaliar a produção científico-acadêmica de Ciências da Comunicação do que indexadores como o Scopus e a Web of Science.

Em comunicado por e-mail a pesquisadores da área de Comunicação, em 13 de abril de 2013, os membros do Comitê de Assessoramento da área de Comunicação no CNPq afirmaram que na avaliação do conjunto de bolsistas da entidade, foi usada a consulta ao Google Scholar, já que a área de Comunicação, assim como "grande parte das humanidades", não possui índice de impacto (o "fator H"). "Em que pese o caráter ainda experimental desse uso, ele se revelou significativo, pois apontou uma clara distinção entre os bolsistas PQ 1 e PQ2 no seu conjunto".

Uma pesquisa realizada pelos espanhóis DELGADO \& REPISO (2013), professores da Universidade de Granada, selecionou periódicos de Comunicação indexados nas três bases (Google Scholar Metrics, Scopus e Web Of Science), calculou o fator $\mathrm{H}$ de cada um deles e os ranqueou, observando a correlação entre os indexadores. As conclusões são bastante interessantes, pois apontam para um maior número (o dobro) de periódicos indexados pelo Google Scholar em relação aos outros dois, bem como a quebra de hegemonia de estudos e periódicos na língua inglesa. Algumas conclusões interessantes do estudo:

- O Google Scholar Metrics (GSM) cobre apenas 41,7\% do total de jornais encontrados na área de Ciências da Comunicação, já que o critério adotado é de inclusão de periódicos com mais de cem artigos publicados nos últimos cinco anos, excluindo aquelas publicações mais jovens ou mais velhas, porém com menor número de artigos;

- O GSM (65,3\%) reduz a hegemonia da língua inglesa historicamente ocorrida tanto no Web Of Science (87,8\% dos jornais indexados em Comunicação) quanto na Scopus (91,6\%);

- O GSM indexa periódicos de maior número de países (30 países contra 23 do Scopus e 13 do Web Of Science) e tem porcentagem menor de periódicos dos 
Estados Unidos e do Reino Unido (53,79\% do total) em comparação com Scopus (74,85\%) e Web Of Science $(80,19 \%)$.

- O GSM dá espaço para países com peso inegável (grifo nosso) na produção de periódicos de Comunicação, como China e Brasil “cujos jornais nem aparecem no Web Of Science e apenas simbolicamente no Scopus" (DELGADO \& REPISO, 2013: 48) 3$)^{33}$.

É interessante observar um resumo da tabela "Origem geográfica coberta pelo Google Scholar Metrics, Web Of Science e Scopus", do trabalho dos pesquisadores de Granada e que reproduzimos de maneira resumida a seguir, apenas para mostrar a participação do Brasil:

Tabela 4 - COBERTURA POR PAÍSES DO GOOGLE SCHOLAR METRICS, WEB OF SCIENCE E SCOPUS

\begin{tabular}{|c|c|c|c|c|c|c|}
\hline \multirow{2}{*}{ País } & \multicolumn{2}{|c|}{ Google Scholar Metrics } & \multicolumn{2}{|c|}{ Scopus } & \multicolumn{2}{c|}{ Web Of Science } \\
\cline { 2 - 7 } & $\begin{array}{c}N^{\circ} \text { de } \\
\text { periódicos }\end{array}$ & $\%$ & $\begin{array}{c}N^{\circ} \text { de } \\
\text { periódicos }\end{array}$ & $\%$ & $\begin{array}{c}N^{\circ} \text { de } \\
\text { periódicos }\end{array}$ & $\%$ \\
\hline $\begin{array}{c}\text { Estados } \\
\text { Unidos }\end{array}$ & 80 & 28,9 & 71 & 42,5 & 45 & 42,4 \\
\hline Reino Unido & 69 & 24,9 & 54 & 32,3 & 39 & 37,7 \\
\hline China & 27 & 9,7 & 0 & 0 & 0 & 0 \\
\hline Brasil & 25 & 9 & 3 & 1,8 & 0 & 0 \\
\hline
\end{tabular}

Fonte: DELGADO \& REPISO, 2013: 49

É válido apontar que os três periódicos brasileiros de Comunicação no Scopus que faziam parte desse banco de dados em 2012, ano em que a pesquisa espanhola foi feita, eram A) Interface: Comunicação, Saúde, Educação (B1 pelo WebQualis de Ciências Sociais Aplicadas 1), B) Perspectivas em Ciências da Informação e C) Transinformação, sendo esses dois últimos periódicos das áreas de Informação e não de Comunicação essencialmente (ambos A1 pelo WebQualis).

No Google Scholar Metrics, os 25 periódicos brasileiros considerados são os mostrados na tabela 5 a seguir

33. Tradução nossa. 
Pesquisadores brasileiros em Periódicos Científicos de Ciências da Comunicação

Tabela 5 - ÍNDICE H DOS PERIÓDICOS BRASILEIROS DE COMUNICAÇÃO NO GOOGLE SCHOLAR METRICS $(2007-2011)^{34}$

\begin{tabular}{|c|c|c|c|}
\hline Posição & Título & H Index ${ }^{35}$ & Med H Index ${ }^{36}$ \\
\hline 39 & Interface - Comunicação, Saúde, Educação & 19 & 26 \\
\hline 103 & MATRIZes & 9 & 19 \\
\hline 108 & Comunicação, Mídia e Consumo & 9 & 15 \\
\hline 115 & Revista Famecos: mídia, cultura e tecnologia & 9 & 11 \\
\hline 120 & Comunicação \& Educação & 8 & 10 \\
\hline 122 & Comunicação em Ciências da Saúde & 8 & 9 \\
\hline 145 & Líbero & 6 & 10 \\
\hline 149 & $\begin{array}{l}\text { Economia Política das Tecnologias da } \\
\text { Informação e da Comunicação }\end{array}$ & 6 & 8 \\
\hline 158 & Revista da Intercom & 6 & 7 \\
\hline 166 & Distúrbios da Comunicação & 5 & 14 \\
\hline 168 & Brazilian Journalism Research & 5 & 11 \\
\hline 170 & Estudos em Jornalismo e Mídia & 5 & 10 \\
\hline 172 & Revista Organicom & 5 & 9 \\
\hline 175 & Informação e Sociedade & 5 & 8 \\
\hline 182 & Intexto & 5 & 7 \\
\hline 193 & Em Questão & 4 & 7 \\
\hline 202 & Comunicação \& Sociedade & 4 & 5 \\
\hline 202 & $\begin{array}{l}\text { Contemporanea - Revista de Comunicação } \\
\text { e Cultura }\end{array}$ & 4 & 5 \\
\hline 214 & Ciberlegenda & 4 & 4 \\
\hline 214 & Conexão - Comunicação e Cultura & 4 & 4 \\
\hline 225 & Discursos Fotográficos & 3 & 7 \\
\hline 242 & Revista Internacional de Folkcomunicação & 3 & 3 \\
\hline 243 & $\begin{array}{l}\text { Rumores - Revista de Comunicação, } \\
\text { Linguagem e Mídias }\end{array}$ & 2 & 9 \\
\hline 245 & $\begin{array}{l}\text { Linguagens - Revista de Letras, Artes e } \\
\text { Comunicação }\end{array}$ & 2 & 4 \\
\hline 252 & Comunicação e Inovação & 2 & 2 \\
\hline
\end{tabular}

34. Lista considerada como periódicos de Comunicação por Delgado \& Repiso (2013).

35. O índice $\mathrm{H}$ foi criado em 2005 por Jorge Hirsch, professor da área de Física da Universidade da Califórnia para avaliar o impacto da produção individual dos pesquisadores. "O índice H de um pesquisador é definido com o número de artigos publicados pelo pesquisador, os quais obtenham citações maiores ou iguais a esse número. Por exemplo, quando dizemos que o índice $\mathrm{H}$ de um pesquisador é dez, significa que ele tem, pelo menos, dez artigos publicados, cada um deles com, pelo menos, dez citações" (THOMAZ; ASSAD e MOREIRA, 2011: 91).

36. Mediana $\mathrm{H}$ de uma publicação consiste na média de citações para os artigos que compõem seu índice H. Um exemplo prático pode ser visto no anexo 2. 
A tabela 5 aponta, portanto, que o Google Scholar Metrics contempla um maior número de revistas da área da Comunicação do que as demais bases de dados do comparativo e o faz também com melhor qualidade, já que os periódicos listados são citados em trabalhos acadêmicos da área e têm sua qualidade reconhecida pelo sistema WebQualis. Por isso, é possível afirmar que no caso do campo dos periódicos das Ciências da Comunicação no Brasil, o Google Scholar parece ser o índice mais adequado para uma avaliação.

Usando dados empíricos, mostram-se limitações de ambos os serviços e refuta-se a ideia muito popular em certos meios académicos de que a base de dados WoS seja uma referência credível: na realidade ambos resultam em imagens incompletas da realidade. Mas argumenta-se que o futuro será de modelos disruptivos tipo GS e que os resultados desse modelo dão protagonismo e visibilidade às múltiplas facetas da actividade cientifica e académica, cuja omissão prejudica na realidade o desenvolvimento da ciência e do conhecimento (BEIRA, 2010: 133).

A importância de discutirmos as métricas de citações dos periódicos em Comunicação neste trabalho é, mais uma vez, apontar para as pressões sofridas por esses por meio dos mais diversos índices, indexadores e bases de dados e até pelo próprio sistema WebQualis, uma vez que este serve-se da seleção prévia feita por indicadores para classificar os periódicos entre os estratos A1 e B5. É preciso que pesquisadores da área questionem-se a respeito da importância de alguns indexadores para seu campo, já que alguns deles podem ser mais ou menos relevantes de acordo com a área acadêmica em questão. Esse fenômeno não é exclusivo da área de Comunicação - já há artigos científicos das mais diversas áreas que questionam os métodos, a importância e a representatividade de cada indexador e base de dados para seu campo em específico.

No próximo capítulo, discutiremos mais profundamente a questão do campo da Comunicação, sua formação e atual status acadêmico no Brasil. 


\section{Capitulo 3}

\section{O PERFIL INSTITUCIONAL DAS CIÊNCIAS DA COMUNICAÇÃO NO BRASIL}

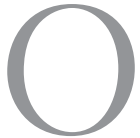

S ESTUDOS UNIVERSITÁRIOS das Ciências da Comunicação no Brasil tiveram início em 1963, com a fundação, por Luiz Beltrão, do Instituto de Ciências da Informação (ICINFORM), primeiro centro acadêmico nacional de estudos midiáticos na Universidade Católica de Pernambuco.

Falar de uma ciência é imaginá-la com as amarras da objetividade e do que se conhece como cientificidade, no sentido de métodos cartesianos como únicos capazes de chegar a uma suposta verdade científica, sem levar em conta os critérios externos a uma pesquisa (como o pensamento científico dominante em certa época e local) (CERVO \& BERVIAN, 1996). No entanto, não se pode pensar em sociologia ou epistemologia de uma ciência se não existir uma ciência a ser analisada e um conhecimento a ser construído, já que o próprio conceito de epistemologia é o de ser o estudo do conhecimento científico. E, embora os estudos comunicacionais no país sejam recentes em relação a outras áreas científicas, neste trabalho tomamos como ponto de partida que as Ciências da Comunicação são um campo, inserido dentro do conceito que Bourdieu desenvolve a esse respeito, produtor de um saber que pode ser aproximado epistemologicamente da Ciência (MARTINO, 2003: 100). Essa condução é bastante suficiente para o desenvolvimento do trabalho e, dessa maneira, não entraremos na discussão, para nós infrutífera, se a Comunicação é ou não uma ciência. 
Partindo desse raciocínio, agora destacamos os principais aspectos da consolidação do campo da Comunicação no Brasil, já que isso é essencial para a análise empírica que tem início no capítulo 4.

No entanto, é preciso destacar que, ainda no século XXI, permanecem debates clássicos a respeito do campo da Comunicação no Brasil. Entre tantos, podemos citar a persistência na pergunta sobre qual o objeto de estudos da Comunicação - a Comunicação interpessoal e/ou a comunicação mediada por dispositivos e tecnologia? - e a separação entre os estudos e pesquisas teóricos e práticos.

Ainda que partamos do consenso de que a Comunicação é um campo interdisciplinar ou mesmo transdisciplinar, é preciso que ela seja "mais do que uma interseção passiva ou um simples efeito de diferentes orientações do saber" (MARTINO, 2003a: 27) - que sua interdisciplinaridade ou transdisciplinaridade seja "fruto de uma exigência do próprio objeto". Então, para isso, seria preciso explicitar qual esse objeto. Algumas pistas a esse respeito serão vistas nos capítulos 4 e 5 , em que analisamos os periódicos científicos do campo.

\subsection{A COMUNICAÇÃO COMO CAMPO}

Fazer uma análise da produção científico-acadêmica de um campo de conhecimento, como a tarefa a que nos propomos neste trabalho, que observa as publicações científicas mais bem avaliadas de acordo com um sistema classificatório proposto pela Capes, significa discutir epistemologicamente essa produção. E, conforme Martino (2003: 70),

discutir epistemologia é necessariamente uma tomada de posição. Significa aceitar certos pressupostos que são aqueles mesmos sobre os quais se funda a ciência: a possibilidade de conhecer o real a partir de certos critérios de investigação, entre os quais a reflexão crítica, a objetividade, a produção da verdade pela argumentação e comprovação

No entanto, acreditamos que a produção da ciência e dos estudos do campo não depende apenas da capacidade e da bagagem acadêmico-científica de seus pesquisadores e autores, tampouco apenas do que SCHAFF (1978) chama de "fator subjetivo"37, senão que está totalmente relacionada às condições de produção em que está inserida, conforme Lopes (2003: 278).

37. Para Schaff, fator subjetivo é "a emanação do sujeito no processo do conhecimento" e que possui um caráter não individual e subjetivo, senão objetivo e social, posto que o sujeito tem papel ativo no processo do conhecimento "por intermédio dos fatores que determinam o psiquismo e as atitudes do sujeito". Os fatores são "a estrutura do aparelho perceptivo do sujeito, a língua com a qual este pensa e que o dota de um aparelho conceitual determinando uma articulação e uma percepção determinadas da realidade, e os interesses de classe ou de grupo que decidem conjuntamente a escolha pelo indivíduo do seu sistema de valores etc" (SCHAFF, 1978: 90). 
Capítulo 3 - O perfil institucional das Ciências da Comunicação no Brasil

Dessa forma, tomamos como base nesse trabalho a sociologia da ciência de Bourdieu para pensar as condições em torno da produção científica do campo das Ciências da Comunicação.

[...] a sociologia da ciência se volta então para a análise das instituições de pesquisa, onde são desenvolvidos os conhecimentos científicos, procurando analisar a interferência dos fatores coletivos. De certa forma ela completa a história da ciência, pois além de negar uma autonomia do conhecimento em relação ao social, metodologicamente aborda a ciência enquanto uma prática social, sujeita portanto às determinações típicas dessa ordem, tais como os problemas de sociologia das profissões, de condicionamentos culturais, de disputas partidárias, de correntes ideológicas, de lutas de poder pelo controle institucional, enfim, tudo o que liga o conhecimento ao poder e à cultura de modo geral (MARTINO, 2003: 77).

É assim, dentro desses marcos da sociologia da ciência, que Pierre Bourdieu desenvolve sua noção de campo científico. Antes de chegar a isso, exploremos a noção de campo, como "espaço social estruturado, um campo de forças - há dominantes e dominados, há relações constantes, permanentes, de desigualdade, que se exercem no interior desse espaço - que é também um campo de lutas para transformar ou conservar esse campo de forças" (BOURDIEU, 1997: 57).

Dessa maneira, partimos para a definição de campo científico, "enquanto sistema de relações objetivas entre posições adquiridas (em lutas anteriores), é o lugar, o espaço de jogo de uma luta concorrencial" (BOURDIEU, 1983: 122). O que está em jogo nessa luta, segundo Bourdieu, é a manutenção do monopólio, da fala e da ação legítimas, "isto é, de maneira autorizada e com autoridade", outorgada a agentes determinados, aqueles de maior capital social dentro do campo (Ibid.: 123).

Por isso é importante analisar as instituições que regem o campo, que têm o poder de decisão nas políticas que influenciam financiamento de pesquisa, classificação de periódicos e até os temas aceitos como sendo legítimos de serem discutidos e pesquisados sob o olhar da Comunicação. Todas essas forças em luta acabam por naturalizar e constituir um modus operandi científico para esse campo, um habitus, um "conhecimento adquirido e também um haver, um capital" (BOURDIEU, 2010: 23),

... que funciona em estado prático segundo as normas da ciência sem ter essas normas na sua origem: é esta espécie de sentido do jogo científico que faz com que se faça o que é preciso fazer no momento próprio, sem ter havido necessidade de tematizar o que havia que fazer, e menos ainda a regra que permite gerar a conduta adequada (Idem). 
As instituições, universidades, linhas de pesquisa, pesquisadores, periódicos científicos e toda a estrutura institucional que rege um campo científico são os agentes de maior ou menor capital social que acabam por impor e naturalizar o habitus do campo que tende a se reproduzir. Bourdieu aponta que a luta é sempre por manutenção do poder simbólico dentro do campo por parte daqueles que o possuem, privilegiando, por meio de estratégias de reconhecimento, os demais agentes que os mantêm no poder e que podem sucedê-los, desde que sejam seus continuadores. Isso, claro, não é exclusividade do campo da Comunicação - são as relações que ocorrem nos campos científicos em geral.

Nos capítulos anteriores, apresentamos as exigências de bases de dados, indexadores e do WebQualis, da Capes, para os periódicos científicos nos quais os pesquisadores dos programas de pós-graduação publicam. Embora não seja o objetivo do presente trabalho, podemos citar que há ainda outras exigências que regem o campo e expõem a questão do capital científico, equivalente ao capital social, porém no campo científico. Se pegarmos como exemplo a pós-graduação no Brasil, a avaliação dos programas pela Capes impõe uma série de exigências, que mais uma vez irá classificar e posicionar esses programas dentro de uma lógica de mérito do campo. Há, no entanto, outros estudos, artigos e ensaios das mais diversas áreas do conhecimento que abordam, do ponto de vista crítico, sobre a política de pós-graduação no país, que não nos cabe aqui.

\subsection{A INSTITUCIONALIZAÇÃO DAS CIÊNCIAS DA COMUNICAÇÃO NO BRASIL}

O pensamento comunicacional, como definiu Miège (2000: 15; 128), teve sua origem a partir da união dos conhecimentos gerados pela prática profissional como pelos aportes teóricos desenvolvidos por pesquisadores e acadêmicos da área. "Aí se encontra um fenômeno fundamental e específico (em parte) do campo da comunicação" (Ibid.: 15). O mesmo aconteceu no desenvolvimento do campo no Brasil, somando-se a essa junção da prática com a teoria, a herança recebida pelas tradições norte-americanas, principalmente no que diz respeito à formação profissional, e europeias, nas contribuições teóricas. Porém, no momento, estamos menos preocupados em seguir as fases do pensamento comunicacional do que a formação do campo no Brasil. Para isso, faremos uma breve apresentação sobre a fundação dos departamentos de Comunicação e especialmente sobre a consolidação das pesquisas, procurando entender como se deu o estabelecimento das instituições da área no país.

O impulso inicial para os estudos de Comunicação veio do grande desenvolvimento da comunicação de massa no país, a partir da década de 1950, embora 
Capítulo 3 - O perfil institucional das Ciências da Comunicação no Brasil

estudos embrionários tenham começado ainda no século XIX sobre a imprensa, colocando como o primeiro objeto comunicacional a suscitar pesquisas. (LOPES, 2005:17; MELO, 2007: 39).

De maneira institucional, pode-se afirmar que as primeiras pesquisas de Comunicação realizadas no Brasil surgiram de ambientes profissionais sob a demanda das indústrias culturais que emergiam entre as décadas de 1940 e 1950, levando à formação de agências privadas para estudos de opinião pública, audiência dos meios de massa e persuasão dos consumidores, baseadas no Paradigma Informacional. O ano de 1945 marcou a primeira sondagem eleitoral feita pelo Instituto Brasileiro de Opinião Pública e Estatística (Ibope) e, no ano seguinte, Carlos Rizzini lançou o primeiro ensaio sobre imprensa e jornalismo sob o título O livro, o jornal e a tipografia no Brasil (MELO, 2007: 69).

Em 1959, é fundado o Centro Internacional de Estudios Superiores de Comunicación para América Latina (Ciespal), instituição que acaba por reunir a primeira geração de pesquisadores da área na América Latina e que terá papel importante e bastante influência nas primeiras escolas de Comunicação dos países que a constituem. É na década de 1960 que as escolas de jornalismo existentes no país começam a ampliar a formação para outras carreiras, como publicidade, relações públicas, cinema, rádio e televisão, ainda que esse crescimento não signifique investir no desenvolvimento de pesquisa em todos os casos. Um grande marco para a área aconteceu em 1963, com a fundação do Instituto de Ciências da Informação na Universidade Católica de Pernambuco, o primeiro centro acadêmico nacional voltado a pesquisas midiáticas. O fundador, Luiz Beltrão, foi também o primeiro doutor em Comunicação do país e criador da linha de estudos em folkcomunicação (Ibid.: 41; 69; 143; 200). Esses primeiros trabalhos são marcados por uma união forte dos cientistas da área em toda a América Latina, que pretendem aplicar as estratégias de comunicação democrática nas políticas públicas nacionais, atendendo a demandas de comunidades periféricas (Ibid.: 107). O instituto fechou as portas em 1964, com o início do governo militar. No entanto, a USP cria, em 1966, a Escola de Comunicações Culturais (hoje Escola de Comunicações e Artes) e, em 1967, a Faculdade de Jornalismo Cásper Líbero funda o Centro de Pesquisas em Comunicação Social.

A década de 1970 dá início a uma nova era nos estudos de Comunicação, uma vez que são criados os espaços de pós-graduação. Embora o hoje Programa de Estudos Pós-Graduados em Comunicação e Semiótica da PUC-SP tenha esse nome, ele nasceu, em 1970, como mestrado de Teoria Literária e Literatura (o doutorado teve início em 1978) e seu foco mudou para Comunicação em 1980. No entanto, como nosso foco é a Comunicação, vamos considerar os primeiros 
mestrados da área como sendo os da USP e da UFRJ, em 1972 (doutorado teve início em 1980 na USP e 1983 na UFRJ), conforme listado na Tabela 6.

A criação dos cursos em pós-graduação da área no Brasil aconteceu na mesma época em outros países da América Latina, o que promoveu o início de uma maior circulação entre teorias e metodologias que hoje caracterizam o campo como interdisciplinar, "da semiótica à psicanálise, das correntes pós-modernistas aos postulados neoliberais" (Ibid.: 40), que se mesclaram às ideias das pesquisas de mídia iniciais na região. "A marca distintiva de todas essas elaborações científicas é o hibridismo teórico e a superposição metodológica, plasmando uma singular investigação mestiça, representativa da fisionomia cultural latino-americana" (Idem).

Dessa maneira, o conhecimento empírico sobre os processos midiáticos ganha força e, na década de 1980, "ocorre a transição do que temos denominado Escola de Pensamento (marcada pelo protagonismo de lideranças exponenciais que atuaram coletivamente) para a formação de uma Comunidade Científica", conforme define Melo (Ibid.: 41-42), esboçando os traços de um campo específico "situado na fronteira do sistema acadêmico com o sistema produtivo" (Ibid.: 200). O autor estabelece como sendo nos anos de 1990 que o campo começa a legitimar-se, e vemos o século XXI trazer cada vez mais transformações e desafios às Ciências da Comunicação com as novas tecnologias de comunicação e informação (TICs) e com a revolução dos meios tradicionais de comunicação. Além dos dispositivos, as múltiplas telas, a interatividade e a cultura participativa, bem como o papel dos profissionais da Comunicação, também se apresentam como desafios aos estudos do campo (MORAIS, 2014; BARBOSA, 2013; MAGNONÍ \& MIRANDA, 2013).

Tabela 6 - PROGRAMAS DE PÓS-GRADUAÇÃO EM CIÊNCIAS DA COMUNICAÇÃO RECONHECIDOS PELA CAPES

\begin{tabular}{|c|c|c|}
\hline & Instituição & Ano de criação/reconhecimento Capes \\
\hline 1 & USP - Comunicação & 1972 \\
\hline 2 & UFRJ & 1972 \\
\hline 3 & Umesp & 1978 \\
\hline 4 & UnB & 1978 \\
\hline 5 & PUC-SP & 1980 \\
\hline 6 & Unicamp & 1986 \\
\hline 7 & UFBA & 1990 \\
\hline 8 & PUCRS & 1994 \\
\hline 9 & Unisinos & 1994 \\
\hline
\end{tabular}


Capítulo 3 - O perfil institucional das Ciências da Comunicação no Brasil

\begin{tabular}{|c|c|c|}
\hline & Instituição & Ano de criação/reconhecimento Capes \\
\hline 10 & UFMG & 1995 \\
\hline 11 & UFRGS & 1995 \\
\hline 12 & UFF - Comunicação & 1997 \\
\hline 13 & Unip & 1997 \\
\hline 14 & UTP & 1999 \\
\hline 15 & UFPE & 2001 \\
\hline 16 & Unesp & 2001 \\
\hline 17 & Ueri & 2002 \\
\hline 18 & PUC-RJ & 2003 \\
\hline 19 & ESPM & 2006 \\
\hline 20 & UFSM & 2006 \\
\hline 21 & $\mathrm{FCL}$ & 2006 \\
\hline 22 & UAM & 2006 \\
\hline 23 & Uniso & 2006 \\
\hline 24 & PUC-MG & 2007 \\
\hline 25 & UFSC & 2007 \\
\hline 26 & UFG & 2007 \\
\hline 27 & UFJF & 2007 \\
\hline 28 & UCB & 2008 \\
\hline 29 & UEL & 2008 \\
\hline 30 & Ufam & 2008 \\
\hline 31 & UFC & 2008 \\
\hline 32 & UFPB & 2008 \\
\hline 33 & UFSCAR & 2008 \\
\hline 34 & USP - Meios e processos audiovisuais & 2009 \\
\hline 35 & UFRN & 2009 \\
\hline 36 & USCS & 2009 \\
\hline 37 & UFMS & 2010 \\
\hline 38 & UFPA & 2010 \\
\hline 39 & UFPI & 2010 \\
\hline 40 & UFPR & 2010 \\
\hline 41 & UFS & 2011 \\
\hline 42 & UEPG & 2012 \\
\hline 43 & UFF - Mídia e Cotidiano & 2012 \\
\hline 44 & UFES & 2014 \\
\hline 45 & UFOP & 2014 \\
\hline
\end{tabular}

Fonte: Capes e Compós 


\subsubsection{As associações como parte do crescimento da área}

Em texto publicado em 1999, José Marques de Melo fala dos novos desafios das Ciências da Comunicação, cuja pesquisa latino-americana estava comemorando seu cinquentenário à época. $\mathrm{O}$ autor cita, além da Intercom, apenas três outras associações acadêmicas da área já existentes naquela data - a Associação Brasileira de Escolas de Comunicação (Abecom), fundada em 1984; a Compós (1991) e a Executiva Nacional dos Estudantes de Comunicação Social (Enecos), também de 1991. Em 2015, o site da Federação Brasileira das Associações Científicas e Acadêmicas de Comunicação (Socicom - criada em 2008) lista 14 associações filiadas, conforme mostra a tabela 7. Dessas, apenas cinco foram fundadas antes do ano 2001. Isso mostra, a exemplo do histórico dos programas de pós-graduação da área, que as Ciências da Comunicação têm passado por um processo de expansão e amadurecimento institucional a partir da entrada no século XXI, ainda que não se possa afirmar que haja um fortalecimento do campo pensado em sua integralidade de conhecimentos, já que boa parte das associações contempla grupos bastante específicos, dentro das habilitações da Comunicação, como jornalismo, relações públicas, publicidade e outros.

Tabela 7 - ASSOCIAÇÕES FILIADAS À SOCICOM

\begin{tabular}{|l|c|c|}
\hline \multicolumn{1}{|c|}{ Filiadas Socicom } & Sigla & Ano de fundação \\
\hline Associação Brasileira de Jornalismo Científico & ABJC & 1977 \\
\hline Associação Brasileira de Estudos Semióticos & ABES & 2001 \\
\hline $\begin{array}{l}\text { Associação Brasileira de Pesquisadores de Comunicação } \\
\text { Organizacional e Relações Públicas }\end{array}$ & Abrapcorp & 2006 \\
\hline Associação Brasileira de Pesquisadores de História da Mídia & Alcar & 2001 \\
\hline $\begin{array}{l}\text { Sociedade Brasileira de Estudos Interdisciplinares da } \\
\text { Comunicação }\end{array}$ & Intercom & 1977 \\
\hline Associação Brasileira de Pesquisadores em Jornalismo & SBPJor & 2003 \\
\hline Associação Brasileira de Pesquisadores em Publicidade & ABP2 & 2010 \\
\hline $\begin{array}{l}\text { Capítulo Brasil da União Latina de Economia Política da } \\
\text { Informação, da Comunicação e da Cultura }\end{array}$ & ULEPICC-Brasil & 2004 \\
\hline Associação Brasileira de Pesquisadores em Cibercultura & ABCiber & 2006 \\
\hline Fórum Nacional de Professores de Jornalismo & FNPJ & 1994 \\
\hline Folkcomunicação & Folkcom & 1998 \\
\hline Fórum Brasileiro de Ensino de Cinema e Audiovisual & Forcine & 2001 \\
\hline $\begin{array}{l}\text { Sociedade Brasileira de Profissionais e Pesquisadores de } \\
\text { Comunicação Política e Marketing Político }\end{array}$ & Politicom & 2002 \\
\hline Sociedade Brasileira de Estudos de Cinema e Audiovisual & Socine & 1996 \\
\hline Fonte: Socicom & & \\
\hline
\end{tabular}

Fonte: Socicom 
Capítulo 3 - O perfil institucional das Ciências da Comunicação no Brasil

\subsection{UM RETRATO DO CAMPO ACADÊMICO NO SÉCULO XXI}

O documento de área mais recente publicado pela Capes é de 2013 e aponta 63 cursos de pós-graduação em Comunicação, sendo 20 doutorados, 42 mestrados acadêmicos e um mestrado profissional) ${ }^{38}$. Em relação à distribuição geográfica desses cursos, a maioria se concentra no Sudeste $(52,2 \%)$, especialmente São Paulo $(27,8 \%)$ e Rio de Janeiro (17,8\%), seguido pela região Sul, com $21,1 \%$ dos cursos de pós.

Sem dúvida, é possível afirmar que a área tem se consolidado no país e já obteve reconhecimento institucional. Porém, no campo teórico-científico, a Comunicação, ao aceitar sua condição de transdisciplinaridade, pode ser construída como um

saber que se relaciona a um processo complexo, no qual estão incluídas linguagens, suportes e fluxos comunicacionais e impacto social, no sentido mais amplo do termo, da difusão dessas práticas e produções comunicacionais. $\mathrm{O}$ que está em discussão é a autoconsciência do status epistemológico transdisciplinar da análise, que visualiza o processo de comunicação (BARBOSA, 2000: 9).

E, conforme a própria autora aponta, os desafios neste século XXI vão muito além de sedimentar as teorias e conhecimentos existentes, mas, sobretudo de lançar novos olhares sobre essas teorias. "Só assim se constrói um campo de pesquisa maduro e reconhecido como produtor de conhecimento válido" (Idem).

Dessa maneira, no próximo capítulo, faremos a análise dos cinco periódicos científicos mais bem classificados da área de Comunicação pelo WebQualis com o propósito de analisar o que tem sido publicado, quais temas e por quais autores nacionais.

38. O site da Compós, em 2015, já lista 45 programas de pós, como visto na tabela 6. Esse número corresponde ao total de instituições com pós-graduação na área (algumas mestrado e doutorado; outras apenas mestrado). 


\section{Capítulo 4}

\section{DESCRIÇÃO E ANÁLISE DOS PERIÓDICOS CIENTÍFICOS EM COMUNICAÇÃO}

$\mathrm{F}$

STE TRABALHO PARTE de uma noção de campo da Comunicação configurado como espaço científico (pesquisa), acadêmico (ensino superior) e das práticas profissionais. Isso é importante de ser destacado no início deste capítulo em que exporemos o nosso corpus, estritamente ligado à pesquisa na área de Comunicação, portanto, no que acabamos de chamar de espaço científico (BOURDIEU, 1997; LOPES, 2003; ROMANCINI, 2006).

\subsection{CORPUS DE PESQUISA}

Conforme já explicitado no capítulo 1, a subárea da Comunicação (inserida dentro da área de Ciências Sociais Aplicadas 1) possui 101 periódicos científicos classificados pelo WebQualis trienal 2010-2012 entre os estratos A2 e B5. Nossa contagem exclui os estratos A1, por não contemplar nenhum periódico científico nacional da área de Comunicação; e $\mathrm{C}$, porque refere-se a periódicos considerados como não científicos.

Dessa maneira, tomamos como corpus de estudo os periódicos nacionais mais bem classificados no WebQualis, ou seja, aqueles do estrato A2. São, portanto, 5, conforme Tabela 8: 
Tabela 8 - CORPUS DE PESQUISA

\begin{tabular}{|c|c|c|c|c|c|}
\hline Revista & $\begin{array}{l}\text { Instituição } \\
\text { publicadora }\end{array}$ & Lançamento & Periodicidade & Formato & $\begin{array}{l}\text { ISSN ou } \\
\text { E-ISSN }\end{array}$ \\
\hline E-Compós & $\begin{array}{c}\text { Associação } \\
\text { Nacional dos } \\
\text { Programas de } \\
\text { Pós-Graduação em } \\
\text { Comunicação }\end{array}$ & 2004 & Quadrimestral & On-line & $\begin{array}{c}\text { E-ISSN } \\
1808-2599\end{array}$ \\
\hline $\begin{array}{l}\text { Famecos: } \\
\text { mídia, } \\
\text { cultura e } \\
\text { tecnologia }\end{array}$ & $\begin{array}{l}\text { Programa de } \\
\text { Pós-Graduação } \\
\text { em Comunicação } \\
\text { Social da } \\
\text { Faculdade de } \\
\text { Comunicação } \\
\text { Social da PÚCRS }\end{array}$ & 1994 & Quadrimestral & $\begin{array}{c}\text { Apenas } \\
\text { on-line desde } \\
2010\end{array}$ & $\begin{array}{c}\text { E-ISSN } \\
1980-3729\end{array}$ \\
\hline Galáxia & $\begin{array}{l}\text { Programa de } \\
\text { Pós-Graduação em } \\
\text { Comunicação e } \\
\text { Semiótica } \\
\text { da PUC-SP }\end{array}$ & 2001 & Semestral & $\begin{array}{l}\text { On-line e } \\
\text { impressa }\end{array}$ & $\begin{array}{c}\text { E-ISSN: } \\
\text { 1982- } \\
\text { 2553; ISSN } \\
\text { 1519-311X }\end{array}$ \\
\hline $\begin{array}{l}\text { Revista } \\
\text { Intercom }\end{array}$ & $\begin{array}{c}\text { Sociedade } \\
\text { Brasileira } \\
\text { de Estudos } \\
\text { Interdisciplinares } \\
\text { da Comunicação }\end{array}$ & $\begin{array}{c}1984 \\
\text { (publicada } \\
\text { desde } 1978 \\
\text { como Boletim } \\
\text { Intercom) }\end{array}$ & Semestral & $\begin{array}{c}\text { Impressa } \\
\text { desde 1978; } \\
\text { on-line e } \\
\text { impressa } \\
\text { desde } 2006\end{array}$ & $\begin{array}{c}\text { E-ISSN } \\
1980-3508 \\
\text { e ISSN } \\
1809-5844\end{array}$ \\
\hline MATRIZes & $\begin{array}{c}\text { Programa de } \\
\text { Pós-Graduação em } \\
\text { Ciênciás } \\
\text { da Comunicação } \\
\text { da USP }\end{array}$ & 2007 & Semestral & $\begin{array}{l}\text { Impressa e } \\
\text { on-line }\end{array}$ & $\begin{array}{c}\text { E-ISSN } \\
1982-8160 \\
\text { e ISSN } \\
1982-2073\end{array}$ \\
\hline
\end{tabular}

\subsubsection{E-Compós}

O periódico E-Compós nasceu em 2004 já no formato digital. Conforme mostrado na Tabela 2, exige-se nível mínimo de doutorando para a publicação de artigos. Quadrimestral, possui como seções de $\operatorname{artigos}{ }^{40}$ Dossiê Temático e Temas Livres. Sua equipe editorial conta com comissão editorial, conselho científico e conselho editorial. Por ser o periódico de uma associação de pesquisadores, possui em sua comissão editorial, bem como nos conselhos, pesquisadores de diversas universidades do Brasil. Na primeira análise, realizada em 2013, cujos resultados estão na Tabela 2, o conselho editorial contava com 10 pesquisadores de instituições estrangeiras e 49 de brasileiras. Em nova análise em abril de 2015, não há mais estrangeiros no conselho editorial, agora composto por 58 pesquisadores

39. O E-ISSN é o ISSN da versão on-line. Periódicos que mantêm os dois formatos, impresso e eletrônico, devem possui dois números diferentes de ISSN, um para cada uma das versões. 40. Os periódicos do corpus também apresentam resenhas e entrevistas, porém consideramos neste trabalho apenas os artigos. 
Capítulo 4 - Descrição e análise dos periódicos científicos em Comunicação

de instituições nacionais. É o periódico com menor presença em indexadores e bases de dados (apenas no Latindex e portal da Capes). Embora já tenha nascido digital, o periódico não apresenta nenhuma inovação de formato em relação aos demais do corpus - sua diagramação é bastante parecida com a de uma revista impressa cujos PDFs foram disponibilizados on-line.

\subsubsection{Revista Famecos}

A Famecos nasceu como revista impressa em 1994 e ganhou seu formato digital no ano 2000. Os dois formatos conviveram em paralelo até 2010, quando chegou ao fim a versão impressa. A versão eletrônica, até 2010, era uma reprodução exata da versão impressa - os arquivos da revista impressa eram transformados no formato PDF e publicados dessa maneira no site. Com o fim da edição impressa, o periódico ganhou uma sutil reformulação a partir de 2011, com um novo formato de imagem de capa e algumas pequenas mudanças na diagramação do PDF (agora com alguns detalhes em cores, como o chapéu com o nome de seção). Na apresentação da primeira edição publicada somente em versão on-line, de 2010 (vol. 17 n. 3), apenas é informado ao leitor que a partir de então a revista seria apenas eletrônica, porém não há informações a respeito dos motivos do fim da versão impressa. Quanto à equipe e o conselho editorial, ambos são formados exclusivamente por pesquisadores ligados à PUCRS, já que a revista é do Programa de Pós-Graduação de Comunicação da instituição.

\subsubsection{Galáxia}

Lançada em 2001, a revista Galáxia mantém até o presente momento seus dois formatos: impresso e eletrônico. O editor científico e a comissão editorial são exclusivamente professores e pesquisadores da PUC-SP, instituição responsável pela revista. A versão on-line é a publicação dos PDFs diagramados da revista impressa.

\subsubsection{Revista da Intercom}

É o periódico mais antigo do corpus, nascido como Boletim Intercom, publicação voltada às notícias da Sociedade Brasileira de Estudos Interdisciplinares da Comunicação. Embora tenha assumido o nome de Revista Intercom em 1984, nos primeiros anos ainda continuava a ser mais um instrumento de comunicação da Sociedade com seus sócios do que um periódico científico. Nesse início, seus artigos não possuíam obrigatoriamente palavras-chaves e/ou referências bibliográficas. Assim como a E-Compós, a Revista Intercom pertence a uma sociedade que reúne pesquisadores de diversas instituições, portanto seu conselho editorial é formado 
por representantes de instituições variadas do Brasil. Era o único periódico de Ciências da Comunicação brasileiro a compor a base de dados Scielo no momento em que foi lançada a avaliação WebQualis trienal 2010-2012 e, graças a isso, foi automaticamente avaliado como pertencente ao estrato A2.

\subsubsection{MATRIZes}

O mais jovem dos periódicos do corpus, foi lançado em 2007, em versão impressa e eletrônica. Assim como os outros periódicos descritos acima pertencentes a programas de pós-graduação, a equipe editorial de MATRIZes é toda formada por pesquisadores e professores da USP, instituição à qual pertence.

\subsection{QUESTÕES A SEREM CONSIDERADAS A RESPEITO DO CORPUS}

Após a definição do corpus - os periódicos mais bem avaliados no WebQualis 2010-2012 - apresentou-se a questão do corte temporal mais adequado para este trabalho. Isso porque periódicos como a Revista da Intercom tem edições desde 1984, enquanto MATRIZes, a mais jovem das revistas, foi lançada apenas em 2007. A análise histórica, por meio do estudo de todas as edições de todos os periódicos seria exaustiva e pouco ofereceria em termos comparativos, já que apenas duas das cinco revistas foram lançadas antes dos anos 2000. Dessa maneira, como observamos na Tabela 6, a partir do ano 2000 há um grande crescimento na abertura de cursos de pós-graduação da área de Ciências da Comunicação, o que significa um incremento de professores e pesquisadores que precisam publicar artigos, não só para mostrar sua produção e difundir suas pesquisas, mas também porque a publicação é obrigatória para que seus novos programas sejam bem avaliados pela CAPES. Assim, definimos como corte temporal o ano 2000 para o início da análise dos periódicos e 2012 como data-fim, ano da última avaliação trienal WebQualis da Capes (2010-2012) mais recente.

Definido o corte temporal, consultamos os sites dos periódicos e, após checagem de que todas as edições se encontravam digitalizadas, decidimos trabalhar com a versão on-line, já que é cópia transposta da versão impressa - garantia de que nenhum artigo ou informação corria o risco de perder-se. Realizamos o download dos arquivos de todos os artigos publicados nas revistas entre os anos 2000 e 2012.

Por conta do corte temporal, o número de edições e artigos por revista ficou como mostra a Tabela 9. 
Capítulo 4 - Descrição e análise dos periódicos científicos em Comunicação

Tabela 9 - NÚMERO DE EDIÇÕES E ARTIGOS DO CORPUS

\begin{tabular}{|c|c|c|c|c|c|}
\hline Periódico & $\begin{array}{c}\text { Corte } \\
\text { temporal }\end{array}$ & $\mathbf{N}^{\circ}$ edições & $\begin{array}{c}\mathbf{N}^{\circ} \text { total de } \\
\text { artigos }^{41}\end{array}$ & $\begin{array}{c}\text { Artigos de } \\
\text { autores } \\
\text { brasileiros }\end{array}$ & $\begin{array}{c}\text { Artigos de } \\
\text { autores } \\
\text { estrangeiros }\end{array}$ \\
\hline E-Compós & $2004-2012$ & 25 & 364 & 312 & 52 \\
\hline Famecos & $2000-2012$ & 38 & 557 & 454 & 103 \\
\hline Galáxia & $2001-2012$ & 24 & 267 & 221 & 46 \\
\hline Intercom & $2000-2012$ & 26 & 239 & 189 & 50 \\
\hline MATRIZes & $2007-2012$ & 11 & 130 & 77 & 53 \\
\hline
\end{tabular}

Para análise de cada um dos artigos, foram transcritas para o programa de computador Excel as seguintes informações:

\begin{tabular}{|l|l|l|l|l|l|l|}
\hline Revista & $A n 0^{43}$ & Edição & Título do artigo & Autor & $\begin{array}{c}\text { Filiação e } \\
\text { titularidade }\end{array}$ & $\begin{array}{c}\text { Palavras- } \\
\text { chave }\end{array}$ \\
\hline
\end{tabular}

Na sequência, foi realizado um desmembramento das informações de filiação e titularidade do autor, criando mais duas colunas na tabela, nos quais essas informações foram separadas. Aplicando o valor o (zero) para as linhas em que não havia uma ou ambas as informações sobre o autor, aplicou-se o comando de "classificar de A a Z" do Excel, a fim de facilitar a contagem das categorias. Em seguida, foi feita nova tabela reunindo os resultados, disponível no Anexo 3. Considerando apenas o autor principal (mesmo nos artigos em coautoria), segundo a titularidade, o resultado do total de artigos de autores brasileiros foi o seguinte, mostrado na Tabela 10.

41. Por conta de diferentes formatações entre os textos dos periódicos, foram contabilizados como artigos todos aqueles que possuíam no mínimo palavra-chave e/ou referências bibliográficas. Os que não possuíam nenhuma das duas informações foram excluídos, não considerados artigos científicos. 42. Foram considerados autores brasileiros todos aqueles com filiação no sistema científico-acadêmico brasileiro, de acordo com as informações disponibilizadas no próprio artigo, sem considerar país de nascimento. Foram contabilizados como artigos de autores brasileiros aqueles cujo autor principal era brasileiro, não importa se os demais fossem estrangeiros. A mesma lógica, no sentido inverso, foi aplicada para classificar os artigos de autores estrangeiros.

43. Ano da edição sendo analisada. 
Pesquisadores brasileiros em Periódicos Científicos de Ciências da Comunicação

Tabela 10 - NÚMERO DE ARTIGOS E PORCENTAGEM (\%) DE AUTORES POR TITULAÇÃO

\begin{tabular}{|c|c|c|c|c|c|c|c|c|}
\hline Revistas & $\begin{array}{c}\text { Total de } \\
\text { artigos }\end{array}$ & \multicolumn{2}{|c|}{ Número de artigos (e \%) por titulação acadêmica do autor principal } & \\
\hline E-Compós & 312 & $\begin{array}{c}181 \\
-58 \%\end{array}$ & $59-19 \%$ & $\begin{array}{r}16 \\
-5,2 \%\end{array}$ & $15-4,8$ & 0 & 0 & $41-13 \%$ \\
\hline Famecos & 454 & $\begin{array}{c}5 \\
-1,1 \%\end{array}$ & $10-2,2 \%$ & $\begin{array}{c}1 \\
-0,25 \%\end{array}$ & $1-0,25 \%$ & 0 & 0 & $437-96,2 \%$ \\
\hline Galáxia & 221 & $\begin{array}{c}129 \\
-58,4 \%\end{array}$ & $32-14,5 \%$ & $1-0,4 \%$ & $2-0,8 \%$ & 0 & $1-0,4 \%$ & $56-25,5 \%$ \\
\hline Intercom & 189 & $\begin{array}{c}110 \\
-58 \%\end{array}$ & $22-11,7 \%$ & $13-7 \%$ & $3-1,6 \%$ & $8-4,2 \%$ & 0 & $33-17,5 \%$ \\
\hline MATRIZes & 77 & $\begin{array}{c}48 \\
-62,3 \%\end{array}$ & $6-7,7 \%$ & 0 & 0 & 0 & 0 & $23-30 \%$ \\
\hline Total & 1253 & $\begin{array}{c}473 \\
-37,8 \%\end{array}$ & $129-10,3 \%$ & $\begin{array}{c}31 \\
-2,5 \%\end{array}$ & $21-1,7 \%$ & $8-0,62 \%$ & $1-0,08 \%$ & $590-47 \%$ \\
\hline
\end{tabular}

Já o resultado segundo a titulação para artigos com apenas um autor, apresentamos na Tabela 11.

Tabela 11 - NÚMERO DE ARTIGOS E PORCENTAGEM POR TITULAÇÃO EM ARTIGOS DE UM ÚNICO AUTOR

\begin{tabular}{|c|c|c|c|c|c|}
\hline \multirow{2}{*}{$\begin{array}{c}\text { Titulação do } \\
\text { autor }\end{array}$} & \multicolumn{5}{|c|}{$N^{\circ}$ de artigos e porcentagem de representatividade } \\
\cline { 2 - 6 } & E-Compós & Famecos & Galáxia & Intercom & MATRIZes \\
\hline Doutor & $134(58 \%)$ & $3(0,85 \%)$ & $98(56 \%)$ & $72(55,4 \%)$ & $40(61 \%)$ \\
\hline Doutorando & $46(20 \%)$ & $3(0,85 \%)$ & $26(15 \%)$ & $19(14,6 \%)$ & $5(8 \%)$ \\
\hline Mestre & $9(4 \%)$ & 0 & 0 & $5(3,9 \%)$ & 0 \\
\hline Mestrando & $12(5 \%)$ & 0 & 0 & $1(0,7 \%)$ & 0 \\
\hline Graduado & 0 & 0 & 0 & $7(5,4 \%)$ & 0 \\
\hline $\begin{array}{c}\text { Não } \\
\text { informado }\end{array}$ & $29(12 \%)$ & $360(98,3 \%)$ & $52(29 \%)$ & $26(20 \%)$ & $20(31 \%)$ \\
\hline Total & $230(100 \%)$ & $366(100 \%)$ & $176(100 \%)$ & $130(100 \%)$ & $65(100 \%)$ \\
\hline
\end{tabular}

Na Tabela 12, separamos o número de artigos e porcentagem por número de autores e, na Tabela 13, o número de autores por artigo em coautoria. 
Capítulo 4 - Descrição e análise dos periódicos científicos em Comunicação

Tabela 12 - NÚMERO DE ARTIGOS E PORCENTAGEM POR AUTORIA ÚNICA E COAUTORIA

\begin{tabular}{|c|c|c|c|c|c|}
\hline Revistas & $\begin{array}{c}\text { Total de } \\
\text { artigos }\end{array}$ & Um autor & Coautoria & \% um autor & $\%$ coautoria \\
\hline E-Compós & 312 & 230 & 82 & 73,7 & 26,3 \\
\hline Famecos & 454 & 366 & 88 & 80,6 & 19,4 \\
\hline Galáxia & 221 & 176 & 45 & 79,6 & 20,4 \\
\hline Intercom & 189 & 130 & 59 & 68,7 & 31,3 \\
\hline MATRIZes & 77 & 65 & 12 & 84,4 & 15,6 \\
\hline Total & 1253 & 967 & 286 & 77 & 23 \\
\hline
\end{tabular}

Tabela 13 - COAUTORIAS

\begin{tabular}{|c|c|c|c|c|c|c|c|}
\hline \multirow{2}{*}{ Revistas } & \multicolumn{7}{|c|}{ Coautoria } \\
\cline { 2 - 9 } & Total de artigos em coautoria & \multicolumn{6}{|c|}{ Número artigos por número de autores } \\
\cline { 2 - 9 } & & 2 & 3 & 4 & 5 & 6 & 7 \\
\hline E-Compós & 82 & 62 & 14 & 2 & 2 & 1 & 1 \\
\hline Famecos & 88 & 79 & 8 & 1 & 0 & 0 & 0 \\
\hline Galáxia & 45 & 40 & 3 & 1 & 1 & 0 & 0 \\
\hline Intercom & 59 & 47 & 11 & 1 & 0 & 0 & 0 \\
\hline MATRIZes & 12 & 11 & 1 & 0 & 0 & 0 & 0 \\
\hline
\end{tabular}

A respeito dos autores (sempre autor principal, sejam artigos de um único autor, sejam como aqueles escritos em coautoria), realizamos no Excel uma tabela com todos os nomes encontrados para verificar os que possuem maior número de artigos publicados nos cinco periódicos do corpus entre os anos de 2010 e 2012. A lista completa está apresentada no anexo 4. Na Tabela 14, destacamos aqueles que publicaram ao menos um artigo em pelo menos quatro dos cinco periódicos. Após a extração desse resultado, consultamos a lista ${ }^{44}$ de bolsistas de produtividade em

44. A lista completa para a área de Ciências Sociais Aplicadas 1 está no endereço http://plsqli.cnpq. br/divulg/RESULTADO_PQ_102003.prc_comp_cmt_links?V_COD_DEMANDA=200310\&V_TPO_ RESULT $=$ CURSO\&V_COD_AREA_CONHEC $=60900008 \& V_{-}$COD_CMT_ASSESSOR=AC. Acesso em maio 2015. 
pesquisa ${ }^{45}$ do $\mathrm{CNPq}$, checando se esses autores que mais publicaram nos periódicos do corpus são considerados os mais produtivos pela agência de fomento. E assim, criamos mais uma coluna na tabela, indicando quais são bolsistas e de qual nível (discutiremos essa correlação no capítulo 5).

Tabela 14 - AUTORES QUE APARECEM EM MAIOR NÚMERO DE REVISTAS

\begin{tabular}{|c|c|c|c|c|c|c|c|}
\hline \multirow{2}{*}{ Autor } & \multirow{2}{*}{ Filiação } & \multirow{2}{*}{$\begin{array}{c}\text { Bolsista } \\
\text { produtividade }\end{array}$} & \multicolumn{5}{|c|}{ Revistas } \\
\hline & & & E-Compós & Famecos & Galáxia & Intercom & MATRIZes \\
\hline André Lemos & UFBA & $P Q 1 A$ & $x$ & $x$ & $x$ & $x$ & $x$ \\
\hline Erick Felinto & UERJ & PQ2 & $x$ & $x$ & $x$ & $x$ & $x$ \\
\hline Suzana Kilpp & Unisinos & $P Q 2$ & $x$ & $x$ & $x$ & $x$ & $x$ \\
\hline Alex Primo & UFRGS & PQ2 & $x$ & $x$ & $x$ & & $x$ \\
\hline $\begin{array}{l}\text { Ana Taís } \\
\text { Portanova } \\
\text { Barros }\end{array}$ & UFRGS & - & $x$ & $x$ & $x$ & $x$ & \\
\hline $\begin{array}{c}\text { Antonio Fausto } \\
\text { Neto }\end{array}$ & Unisinos & $P Q 1 A$ & & $x$ & $x$ & $x$ & $x$ \\
\hline $\begin{array}{l}\text { Arlindo } \\
\text { Machado }\end{array}$ & PUC-SP & $P Q 1 A$ & $x$ & $x$ & $x$ & & $x$ \\
\hline Benjamin Picado & UFF & - & $x$ & $x$ & $x$ & & $x$ \\
\hline $\begin{array}{c}\text { Bruno Souza } \\
\text { Leal }\end{array}$ & UFMG & $P Q 2$ & $x$ & $x$ & $x$ & & $x$ \\
\hline \begin{tabular}{|c|} 
Denise Azevedo \\
Duarte \\
Guimarães \\
\end{tabular} & UTP & - & $x$ & $x$ & & $x$ & $x$ \\
\hline Edson Dalmonte & UFBA & $P Q 2$ & & $x$ & $x$ & $x$ & $x$ \\
\hline Gislene Silva & UFSC & $P Q 2$ & $x$ & $x$ & $x$ & & $x$ \\
\hline Marcia Benetti & UFRGS & $P Q 2$ & $x$ & $x$ & $x$ & & $x$ \\
\hline $\begin{array}{c}\text { Maria } \\
\text { Immacolata } \\
\text { Vassallo de } \\
\text { Lopes }\end{array}$ & USP & $P Q 1 A$ & $x$ & $x$ & & $x$ & $x$ \\
\hline $\begin{array}{l}\text { Marialva } \\
\text { Barbosa }\end{array}$ & UFRJ & $P Q 1 D$ & $x$ & $X$ & $x$ & & $x$ \\
\hline
\end{tabular}

Legenda: $\mathrm{x}$ indica a publicação de pelo menos um artigo no periódico.

Quanto à representatividade dos autores de acordo com a filiação, as Tabelas 15 a 19, mostram as universidades de maior ocorrência em cada revista. A Tabela 20 indica as 10 universidades mais representadas em número de autores em todo o corpus.

45. A bolsa de produtividade em pesquisa é destinada a "pesquisadores que se destaquem entre seus pares, valorizando sua produção científica segundo critérios normativos, estabelecidos pelo CNPq, e específicos, pelos Comitês de Assessoramento" http://www.cnpq.br/web/guest/view/-/journal_content/56_INSTA NCE_0oED/10157/100343\#16061 Acesso em maio 2015. 
Capítulo 4 - Descrição e análise dos periódicos científicos em Comunicação

Tabela 15 - DEZ UNIVERSIDADES DE MAIOR OCORRÊNCIA NO PERIÓDICO E-COMPÓS (DE UM TOTAL DE 55 UNIVERSIDADES REPRESENTADAS NAS EDIÇÕES ANALISADAS).

\begin{tabular}{|c|c|}
\hline $\begin{array}{c}10 \text { universidades de maior ocorrência } \\
\text { no periódico E-Compós }\end{array}$ & $\begin{array}{c}\text { Número de ocorrências } \\
\text { (primeiro autor) }\end{array}$ \\
\hline UFRJ & 35 \\
\hline PUCRS & 27 \\
\hline UFF & 23 \\
\hline UFBA & 19 \\
\hline USP & 18 \\
\hline UFMG & 17 \\
\hline UTP & 17 \\
\hline UFRGS & 17 \\
\hline UFPE & 16 \\
\hline Unisinos & 10 \\
\hline
\end{tabular}

Tabela 16 - DEZ UNIVERSIDADES DE MAIOR OCORRÊNCIA NO PERIÓDICO FAMECOS (DE UM TOTAL DE 65 UNIVERSIDADES REPRESENTADAS NAS EDIÇÕES ANALISADAS).

\begin{tabular}{|c|c|}
\hline $\begin{array}{c}10 \text { universidades de maior ocorrência } \\
\text { na revista Famecos }\end{array}$ & $\begin{array}{c}\text { Número de ocorrências } \\
\text { (primeiro autor) }\end{array}$ \\
\hline PUCRS & 85 \\
\hline UFRJ & 36 \\
\hline USP & 27 \\
\hline UFRGS & 27 \\
\hline UERJ & 20 \\
\hline UFBA & 18 \\
\hline UFF & 16 \\
\hline UFPE & 15 \\
\hline PUC-SP & 13 \\
\hline Umesp & 13 \\
\hline Unisinos & 13 \\
\hline
\end{tabular}


Pesquisadores brasileiros em Periódicos Científicos de Ciências da Comunicação

Tabela 17 - DEZ UNIVERSIDADES DE MAIOR OCORRÊNCIA NO PERIÓDICO GALÁXIA (DE UM TOTAL DE 45 UNIVERSIDADES REPRESENTADAS NAS EDIÇÕES ANALISADAS).

\begin{tabular}{|c|c|}
\hline $\begin{array}{c}10 \text { universidades de maior ocorrência } \\
\text { no periódico Galáxia }\end{array}$ & $\begin{array}{c}\text { Número de ocorrências } \\
\text { (primeiro autor) }\end{array}$ \\
\hline USP & 25 \\
\hline PUCSP & 24 \\
\hline UFRJ & 22 \\
\hline UFBA & 12 \\
\hline UFPE & 12 \\
\hline Unisinos & 12 \\
\hline UFMG & 11 \\
\hline UFF & 10 \\
\hline PUC Minas & 6 \\
\hline UFRGS & 6 \\
\hline UTP & 6 \\
\hline
\end{tabular}

Tabela 18 - DEZ UNIVERSIDADES DE MAIOR OCORRÊNCIA NO PERIÓDICO REVISTA DA INTERCOM (DE UM TOTAL DE 81 UNIVERSIDADES REPRESENTADAS NAS EDIÇÕES ANALISADAS).

\begin{tabular}{|c|c|}
\hline $\begin{array}{c}\text { Universidades de maior ocorrência } \\
\text { na Revista da Intercom }\end{array}$ & $\begin{array}{c}\text { Número de ocorrências } \\
\text { (primeiro autor) }\end{array}$ \\
\hline Umesp & 13 \\
\hline UFF & 12 \\
\hline PUCRS & 10 \\
\hline USP & 10 \\
\hline Unisinos & 8 \\
\hline UnB & 7 \\
\hline Unesp & 6 \\
\hline UERJ & 6 \\
\hline UFSC & 5 \\
\hline UFPI & 5 \\
\hline
\end{tabular}


Capítulo 4 - Descrição e análise dos periódicos científicos em Comunicação

Tabela 19 - DEZ UNIVERSIDADES DE MAIOR OCORRÊNCIA NO PERIÓDICO MATRIZES (DE UM TOTAL DE 23 UNIVERSIDADES REPRESENTADAS NAS EDIÇÕES ANALISADAS).

\begin{tabular}{|c|c|}
\hline $\begin{array}{c}\text { Universidades de maior ocorrência } \\
\text { na revista MATRIZes }\end{array}$ & $\begin{array}{c}\text { Número de ocorrências } \\
\text { (primeiro autor) }\end{array}$ \\
\hline USP & 20 \\
\hline UFRJ & 8 \\
\hline PUC-SP & 7 \\
\hline Unisinos & 6 \\
\hline UFBA & 5 \\
\hline UFF & 4 \\
\hline UFRGS & 3 \\
\hline PUC-MG; PUC-RJ; PUCRS; UFMG; UFSM; Unip & 2 (cada) \\
\hline
\end{tabular}

Tabela 20 - UNIVERSIDADES COM MAIOR OCORRÊNCIA EM TODOS OS PERIÓDICOS

\begin{tabular}{|c|c|}
\hline Universidades com maior número de ocorrências & Número de ocorrências total \\
\hline PUCRS & 124 \\
\hline UFRJ & 101 \\
\hline USP & 100 \\
\hline UFF & 65 \\
\hline UFBA & 54 \\
\hline UFRGS & 53 \\
\hline Unisinos & 49 \\
\hline PUC-SP & 44 \\
\hline UFPE & 43 \\
\hline UFMG & 30 \\
\hline Total & 663 \\
\hline & \\
\hline & \\
\hline
\end{tabular}


Das Tabelas 15 a 20, podemos extrair que 10 universidades são responsáveis por $53 \%$ do total de artigos de autores nacionais (663 de 1.253). Dessas dez, as três primeiras respondem por 325 artigos - ou seja, cerca de $25 \%$ da produção de artigos das revistas do corpus são da PUCRS, UFRJ e USP. Dessas dez universidades, sete são públicas (sendo uma estadual - a USP) e três, privadas. Cinco delas são do Sudeste, três do Sul e duas do Nordeste. Ainda dessas dez universidades, nove são casa de programas antigos de pós-graduação em Ciências da Comunicação; apenas a pós-graduação em Comunicação da UFPE é de depois do ano 2000.

\subsection{ARTIGOS POR ÁREAS}

Após a análise dos artigos por autores, filiação, titularidade e universidade, passamos para o estudo dos temas publicados. Para isso, retomamos a primeira planilha de Excel em que colocamos as palavras-chave para analisar os artigos.

A fim de classificar esses artigos por temas, tomamos como base a tabela ${ }^{46}$ de áreas do Conhecimento e subáreas da Comunicação elaborada pelo Conselho da Compós, em abril de 2011, com o objetivo de enviá-la ao CNPq para mudança da classificação atual, segundo demanda dos pesquisadores.

Tabela 21 - SUBÁREAS DA COMUNICAÇÃO PROPOSTAS PELO CONSELHO DA COMPÓS - APLICADA COMO CLASSIFICAÇÃO TEMÁTICA DOS ARTIGOS ANALISADOS

\begin{tabular}{|c|c|}
\hline Epistemologia e Teorias da Comunicação & A \\
\hline Comunicação audiovisual, imagética e sonora & B \\
\hline Tecnologias da comunicação & $\mathrm{C}$ \\
\hline Comunicação jornalística & $\mathrm{D}$ \\
\hline Comunicação em publicidade e propaganda & $\mathrm{E}$ \\
\hline Comunicação organizacional & $\mathrm{F}$ \\
\hline Comunicação e produção editorial & $\mathrm{G}$ \\
\hline Comunicação e processos de recepção, de interação e de consumo & $\mathrm{H}$ \\
\hline Comunicação nas dinâmicas socioculturais ${ }^{47}$ & $\mathrm{I}$ \\
\hline Comunicação e interfaces disciplinares & 48 \\
\hline
\end{tabular}

46. Disponível em http://www.compos.org.br/data/biblioteca_1771.pdf. Acesso em janeiro 2015. 47. Classificamos como sendo da área de Comunicação nas Dinâmicas Socioculturais, os artigos que procuram entender as práticas sociais e culturais de diferentes grupos e sujeitos da contemporaneidade, que buscam entender como se organizam os processos interculturais, sejam eles híbridos, plurais ou de nichos com recortes socioeconômicos, etário, espacial ou de gênero (*interpretação baseada na descrição de linhas de pesquisa de diversos programas de pós-graduação em Comunicação).

48. Classificamos como sendo da área de Comunicação e Interfaces Disciplinares os artigos que trazem contribuições explícitas e de maneira predominante de outras disciplinas com as quais a Comunicação tem interface, como semiótica, filosofia e psicanálise. 
Capítulo 4 - Descrição e análise dos periódicos científicos em Comunicação

Partindo dessa tabela, olhamos para os artigos para classificá-los, primeiramente, por palavras-chave. Em caso de dúvida, partimos para o título e resumo. ${ }^{49}$

Assim, chegamos à seguinte classificação dos artigos, apresentadas nas

Tabelas 22 a 27.

Tabela 22 - NÚMERO DE ARTIGOS POR REVISTA E POR ÁREA DE CLASSIFICAÇÃO TEMÁTICA

\begin{tabular}{|c|c|c|c|c|c|}
\hline \multirow{2}{*}{$\begin{array}{c}\text { Áreas de } \\
\text { classificação } \\
\text { (conforme } \\
\text { tabela 20) }\end{array}$} & E-Compós & Famecos & Galáxia & Intercom & MATRIZes \\
\cline { 2 - 6 } & 17 & 45 & 8 & 29 & 14 \\
\hline A & 78 & 81 & 86 & 25 & 21 \\
\hline B & 34 & 85 & 30 & 21 & 12 \\
\hline C & 33 & 70 & 39 & 51 & 8 \\
\hline D & 7 & 9 & 6 & 7 & 1 \\
\hline E & 2 & 11 & 0 & 6 & 0 \\
\hline F & 4 & 2 & 3 & 1 & 3 \\
\hline G & 26 & 32 & 4 & 9 & 4 \\
\hline H & 69 & 38 & 13 & 24 & 4 \\
\hline I & 42 & 81 & 32 & 16 & 10 \\
\hline J & 312 & 454 & 221 & 189 & 77 \\
\hline Total & & & & & \\
\hline
\end{tabular}

As Tabelas 23 a 27 trazem a porcentagem de artigos de cada revista por área de classificação temática

Tabela 23

\begin{tabular}{|c|c|}
\hline Áreas & E-Compós (\%) \\
\hline A & 5,45 \\
\hline B & 25 \\
\hline C & 11 \\
\hline D & 10,57 \\
\hline E & 2,25 \\
\hline F & 0,65 \\
\hline G & 1,28 \\
\hline H & 8,34 \\
\hline I & 22 \\
\hline J & 13,46 \\
\hline Total & $100 \%$ \\
\hline
\end{tabular}

Tabela 24

\begin{tabular}{|c|c|}
\hline Áreas & Famecos (\%) \\
\hline A & 10 \\
\hline B & 17,85 \\
\hline C & 18,72 \\
\hline D & 15,4 \\
\hline E & 2 \\
\hline F & 2,4 \\
\hline G & 0,44 \\
\hline H & 7,04 \\
\hline I & 8,3 \\
\hline J & 17,85 \\
\hline Total & $100 \%$ \\
\hline
\end{tabular}

Tabela 25

\begin{tabular}{|c|c|}
\hline Áreas & Galáxia (\%) \\
\hline A & 3,62 \\
\hline B & 39 \\
\hline C & 13,57 \\
\hline D & 17,6 \\
\hline E & 2,71 \\
\hline F & 0 \\
\hline G & 1,35 \\
\hline H & 1,8 \\
\hline I & 5,88 \\
\hline J & 14,47 \\
\hline Total & $100 \%$ \\
\hline
\end{tabular}

49. A tabela em Excel com a análise dos artigos de autores brasileiros esetá disponível em CD anexo. 
Pesquisadores brasileiros em Periódicos Científicos de Ciências da Comunicação

Tabela 26

\begin{tabular}{|c|c|}
\hline Áreas & Intercom (\%) \\
\hline A & 15,34 \\
\hline B & 13,22 \\
\hline C & 11,12 \\
\hline D & 27 \\
\hline E & 3,7 \\
\hline F & 3,17 \\
\hline G & 0,55 \\
\hline H & 4,7 \\
\hline I & 12,7 \\
\hline J & 8,5 \\
\hline Total & $100 \%$ \\
\hline
\end{tabular}

Tabela 27

\begin{tabular}{|c|c|}
\hline Áreas & MATRIZes (\%) \\
\hline A & 18,2 \\
\hline B & 27,2 \\
\hline C & 15,6 \\
\hline D & 10,4 \\
\hline E & 1,3 \\
\hline F & 0 \\
\hline G & 3,9 \\
\hline H & 5,2 \\
\hline I & 5,2 \\
\hline J & 13 \\
\hline Total & $100 \%$ \\
\hline
\end{tabular}

\subsection{BIBLIOGRAFIA UTILIZADA PELOS AUTORES BRASILEIROS DOS ARTIGOS}

Depois de ter os artigos de autores brasileiros classificados quanto à universidade à qual estão filiados, sua titularidade, além dos temas desses trabalhos, bem como destacados os autores que mais publicam nos periódicos do corpus, decidimos ampliar o escopo de pesquisa para saber quais autores são os mais ou menos citados (e suas obras) nos artigos dos autores nacionais.

Dessa maneira, procuramos a orientação de um estaticista com o objetivo de obter uma amostra a fim de avaliar relações entre nomes dos autores da bibliografia dos artigos analisados, sua nacionalidade e sua obra. Definiu-se uma amostra de 25\% (313) do total de 1.253 artigos, mantendo a proporcionalidade das revistas, conforme aponta a Tabela 28.

Tabela 28 - NÚMERO DE ARTIGOS E AMOSTRA DIMENSIONADA POR REVISTA.

\begin{tabular}{|c|c|c|}
\hline Revista & N artigos $^{\circ}$ & Amostra \\
\hline E-Compós & 312 & 31 \\
\hline Famecos & 454 & 45 \\
\hline Galáxia & 221 & 22 \\
\hline MATRIZes & 77 & 8 \\
\hline Intercom & 189 & 47 \\
\hline Total & 1253 & 125 \\
\hline
\end{tabular}


Capítulo 4 - Descrição e análise dos periódicos científicos em Comunicação

Uma amostra dessa magnitude é capaz de estimar qualquer proporção de interesse (tipo de assunto citado, se autor estrangeiro ou brasileiro, ou a distribuição dos autores, por exemplo), com confiança de 95\% num intervalo máximo de 8 pontos percentuais para mais ou para menos. (Bussab e Morettin, 2006). Por fim, foi feita uma lista por linhas [do arquivo Excel em CD, ignorando a linha 1, do título] que deveriam ser selecionadas para análise em cada revista. A seleção da amostra foi realizada através da função sample do software R 3.1.2 (R Core Team, 2014). 


\section{Capítulo 5}

\section{DISCUSSÃO - O AUTOR BRASILEIRO NOS PERIÓDICOS CIENTÍFICOS - QUEM SÃO, TEMAS E REFERENCIAS BIBLIOGRÁFICAS PREPONDERANTES}

$\mathrm{P}$ ARA INICIAR A análise dos dados explicitados no capítulo anterior, precisamos esclarecer que nos interessa aqui o autor brasileiro - o pesquisador e/ou professor ligado de alguma maneira ao campo acadêmico científico do país, não importa sua origem natal, conforme explicado em nota de rodapé no capítulo 4. Partindo desse pressuposto, foi levada em conta a filiação do autor (e também sua titularidade) explicitada no artigo em análise. Sabemos, portanto, que a análise que se segue é uma fotografia da produção fixada em cada uma das edições dos periódicos - sem considerar que um mesmo autor, ao longo dos anos, pode ter publicado em periódicos distintos com diferentes titularidades (primeiro, mestre, depois doutor, por exemplo) ou mesmo ligado a diferentes instituições.

\subsection{A TITULARIDADE DOS AUTORES BRASILEIROS}

A Tabela 10, na página 66, indica o número e a porcentagem de artigos pela titulação dos autores principais dos periódicos analisados. Afere-se daí que a maioria dos artigos publicados tem doutores como autores principais, numa porcentagem que vai de $62,3 \%$ de doutores em MATRIZes a, no mínimo, 58\% nos periódicos E-Compós e Intercom (58,4\% em Galáxia), indicando uma exigência de titulação bastante significativa para publicação nesses periódicos. Levando-se em 
conta artigos apenas com um autor, as porcentagens não sofrem grande variação quanto à titulação, conforme mostra a Tabela 11, na página 66 .

A porcentagem de doutorandos varia entre $19 \%$ na E-Compós a $7,7 \%$ em MATRIZes. O índice diminui progressivamente quando se trata de autores principais com título de mestre (MATRIZes não publicou nenhum), mestrando (MATRIZes não publicou nenhum), graduado (ocorrências apenas em Intercom, no total de 8) ou graduando (apenas Galáxia, um artigo).

Nessa análise, fica de fora o periódico Famecos, já que o número de artigos em que a titulação de autor não é especificada é bastante alto, de 437 artigos, o correspondente a $96,2 \%$ da mostra total para essa revista.

Quanto aos demais periódicos, 30\% dos artigos de MATRIZes não identificam a titulação do autor, seguido por 25,5\% em Galáxia, 17,5\% em Intercom e 13\% em E-Compós. A média de artigos sem titulação de autor é de $47 \%$ considerando-se os 5 periódicos e de 19,15\% excluindo-se Famecos.

\subsection{AUTORIA ÚNICA E COAUTORIAS}

A Tabela 12, da página 67, mostra que a taxa de artigos de um único autor ainda é a vasta maioria nos periódicos do corpus, variando de $68,7 \%$ na Revista da Intercom a 84,4\% em MATRIZes, indicando um retrato já tradicional do campo das Humanas de haver poucos artigos em coautoria, ao contrário do que sabidamente acontece em áreas como Biológicas, Saúde e Exatas.

Quando a coautoria acontece, conforme mostra a tabela 13, na página 67, a maior porcentagem é de artigos escritos por duplas, e o periódico E-Compós foi o único a ter publicado (um) artigo assinado por 6 autores e (um) artigo assinado por 7 autores. MATRIZes foi o periódico mais restritivo nesse sentido, tendo publicado apenas um artigo em trio de autores (todas as demais parcerias foram em dupla).

É natural, pela própria natureza da área da Comunicação, que os artigos sejam em sua maioria de um único autor ou de duplas, já que é um campo em que a reflexão teórica, a observação e a análise qualitativa têm maior peso do que nas demais áreas já citadas (Exatas, Saúde etc), nas quais o empírico e o quantitativo têm maior participação, justificando a presença de uma equipe maior de autores, em que alguns podem ter realizado supostamente apenas a coleta de dados, por exemplo.

Embora não tenhamos feito uma análise nessa profundidade, pode-se afirmar com certa segurança, observando o anexo 3 , que há uma boa presença de artigos em coautoria de pesquisadores com diferentes graus de titulação, indicando um trabalho feito por um professor doutor, seus orientandos de pós-graduação e até com o envolvimento dos bolsistas de iniciação científica. Também chama a atenção o número de artigos em dupla em que ambos os autores são doutores. 
Capítulo 5 - Discussão - O autor brasileiro nos periódicos científicos Quem são, temas e referências bibliográficas preponderantes

\subsubsection{Os autores com maior participação}

A partir das tabelas completas de análise, fizemos uma lista dos autores principais (ou único autor) de todos os 1.253 artigos analisados dos cinco periódicos (anexo 4), o que deu um total de 655 autores. Desses, destacamos, na Tabela 14, na página 68, aqueles que publicaram ao menos uma vez em pelo menos quatro dos cinco periódicos, resultando em 15 autores, dos quais apenas 3 não são bolsistas produtividade do CNPq. Ou seja, 12 desses autores têm, não só um número mínimo de duas publicações de artigos por ano, como também uma quantidade considerável de orientações de alunos em pós-graduação, boa qualificação de sua produção Qualis (revista e livros) e são considerados líderes em suas áreas, ao dirigirem grupos de pesquisa, ocuparem cargos de representação nas agências de fomento, coordenarem associações científicas, organizarem eventos, conduzirem acordos interinstitucionais e de alcance internacional, entre outras atividades, conforme demanda o CNPq. Na área de Comunicação, estão na folha de pagamento ${ }^{50}$ da agência de fomento, 124 pesquisadores com bolsa produtividade, sendo 13 PQ 1 A (maior classificação), 13 PQ 1B, 7 PQ 1 C, 20 PQ 1 D e 71 PQ 2. Ainda conforme a Tabela 14, dos 12 autores-bolsistas, 4 são $\mathrm{PQ} 1 \mathrm{~A},{ }_{1} \mathrm{PQ} 1 \mathrm{D}$ e $7 \mathrm{PQ} 2$.

Esses autores não são necessariamente os que possuem maior número de artigos publicados nos periódicos do corpus. No entanto, observou-se que o maior número de artigos de um mesmo autor se dá, na maioria das vezes, em um mesmo periódico. Por esse motivo, não consideramos o número de artigos publicados, e sim aqueles que tiveram participação em maior número de periódicos, a fim de não cairmos em uma suposta armadilha de endogenia ${ }^{51}$, em que um autor só publica em um mesmo periódico, o que poderia deturpar os dados de análise.

Ainda pelo anexo 4, pudemos fazer a contagem de autores por sexo, conforme mostra a Tabela 29, indicando que os autores dos periódicos do corpus são, em sua maioria, mulheres, embora a diferença não seja proporcionalmente tão grande entre os sexos, apenas de $4,6 \%$.

Tabela 29 - AUTORES POR SEXO

\begin{tabular}{|c|c|c|}
\hline Sexo & Número de autores & Porcentagem do total \\
\hline Feminino & 342 & $52,3 \%$ \\
\hline Masculino & 312 & $47,7 \%$ \\
\hline Total & 654 & $100 \%$ \\
\hline
\end{tabular}

50. Em março 2015.

51. Berelson (1960) define endogenia acadêmica como a prática das universidades em contratarem seus ex-alunos, seus doutores, para que permaneçam na instituição onde se formaram. Usamos o termo aqui para indicar a publicação de autores da própria instituição responsável pelo periódico. 


\subsubsection{Filiação dos autores}

Quanto às universidades às quais pertencem os autores brasileiros, pode-se afirmar, de maneira geral, segundo as Tabelas 15 a 19 nas páginas 69 a 71, que a representatividade é parecida em todas as revistas. Portanto, neste caso é importante destacar alguns achados da pesquisa. No caso do periódico E-Compós, a universidade com maior número de artigos é a UFRJ, com 35, menos de $10 \%$ do total de artigos. No entanto, a distribuição de número de artigos por universidade é bastante pareada e há um total de 55 universidades representadas (considerando-se a origem de autores principais ou único autor).

Já no caso do periódico Famecos, a universidade mais presente é a PUCRS, com 85 artigos, cerca de $19 \%$ do total, o que indica endogenia, já que o periódico é publicado por essa universidade. A segunda universidade com maior participação é a UFRJ, com apenas 36 artigos ou 8\% do total, ou seja, menos da metade da participação dos autores da própria PUCRS. A representatividade é de 65 universidades.

O periódico Galáxia, publicado pelo programa de pós-graduação da PUC SP, teve 24 artigos dessa universidade, mas o primeiro lugar de ocorrências ficou com a USP, com 25 artigos. O terceiro lugar foi ocupado pela UFRJ, com 22 artigos, 0 que, do nosso ponto de vista, não indica endogenia, dado o equilíbrio numérico das três primeiras posições. O total de universidades representadas é de 45 .

Na Revista da Intercom, a Umesp tem 13 artigos publicados, porém seguida pela UFF (com 12) e PUCRS e USP (com 10 cada). Embora a Umesp, universidade tradicionalmente ligada aos fundadores da Intercom (em especial o Prof. Dr. José Marques de Melo) tenha mais artigos, proporcionalmente não difere muito da representação em número de artigos das demais universidades. São 81 universidades representadas por meio de artigos - o maior número entre os cinco periódicos do corpus.

O periódico MATRIZes possui uma maioria de artigos da própria instituição publicadora, a USP, com 20 textos. Diferentemente do que ocorre na Famecos, podemos analisar que os dados, sem a presença de MATRIZes indicam ainda predominância no corpus de autores da instituição paulista, que pode ser explicada por sua tradição em pesquisa e ser pioneira no programa de pós-graduação na área . Desta maneira, não consideramos endogenia no caso de MATRIZes, seguida por 8 da UFRJ e 7 da PUC-SP. Do total, os autores da USP correspondem a $26 \%$ dos autores publicados, seguidos por 10,4\% da UFRJ. É o periódico com menor representatividade de universidades, apenas 23 . 
Capítulo 5 - Discussão - O autor brasileiro nos periódicos científicos Quem são, temas e referências bibliográficas preponderantes

Tabela 30 - NÚMERO DE UNIVERSIDADES REPRESENTADAS POR AUTORES DE ARTIGOS NOS PERIÓDICOS

\begin{tabular}{|c|c|}
\hline Periódico & Número de universidades representadas \\
\hline E-Compós & 55 \\
\hline Famecos & 65 \\
\hline Galáxia & 45 \\
\hline Intercom & 81 \\
\hline MATRIZes & 23 \\
\hline
\end{tabular}

No conjunto total dos 1.253 artigos analisados dos cinco periódicos, o maior número de ocorrências é de autores da PUCRS - um total de 124 artigos (10\% do total de artigos estudados), sendo que quase 70\% deles publicados no periódico Famecos, conforme relatado acima. Em seguida vem a UFRJ, com 101 artigos e a USP, com 100 (ou seja, cerca de $8 \%$ de representatividade cada uma no total de artigos). Conforme já relatado no capítulo anterior, as 10 universidades com maior número de artigos publicados correspondem a 53\% do total de 1.253 artigos.

No entanto, se retirarmos os dados da PUCRS - posto que o número de artigos da universidade na Famecos faz com que o índice de participação da instituição aumente consideravelmente ( 85 artigos publicados no periódico da casa), concluímos que, no quadro geral, a USP fica em primeiro lugar, com 73 artigos, seguida pela UFRJ, com 65, UFF com 49, e só então a PUCRS, com 39 artigos. Então, a Tabela 20, da página 71, retirando os dados da PUCRS, ficaria conforme a Tabela 31, a seguir.

Tabela 31 - UNIVERSIDADES COM MAIOR OCORRÊNCIA CONSIDERANDO OS PERIÓDICOS E-COMPÓS, GALÁXIA, INTERCOM E MATRIZES

\begin{tabular}{|c|c|}
\hline Universidades com maior número de ocorrências & Número de ocorrências \\
\hline USP & 73 \\
\hline UFRJ & 65 \\
\hline UFF & 49 \\
\hline PUC-RS & 39 \\
\hline UFBA & 36 \\
\hline Unisinos & 36 \\
\hline PUC-SP & 31 \\
\hline UFMG & 30 \\
\hline UFPE & 28 \\
\hline UFRGS & 26 \\
\hline Total & 413 \\
\hline
\end{tabular}




\subsection{TEMAS DOS ARTIGOS}

Em primeiro lugar, conforme explicado no capítulo 4, olhamos para as palavras-chave a fim de classificar os artigos em temas (Tabela 21, pág. 72).

O uso de palavras-chave é bastante comum e tem sido "um dos principais recursos para refinamento de busca em sistemas de recuperação de informação" (FERREIRA et al, 2009: 152). No entanto, conforme observa a autora, muitas vezes as palavras-chave das revistas científicas de Comunicação são mal aplicadas, com termos que não correspondem aos artigos. Embora consideremos essa questão, adotamos o padrão de, em primeiro lugar, olhar para as palavras-chave dos artigos a fim de classificá-los em um dos 10 temas (Tabela 21). Isso porque embora consideremos a observação acima, partimos do pressuposto que os autores escolhem suas palavras-chave intencionalmente (já que nenhum dos cinco periódicos do corpus restringe o uso de termos no momento de submissão dos artigos na ferramenta de publicação OJS/Seer) e as direcionam para o que acreditam definir melhor seu artigo.

Quando as palavras-chave não forneciam informações suficientes para a classificação - ou quando permitiam alguma ambiguidade - o segundo elemento analisado era o título do artigo e, depois, seu resumo. Apenas em poucos casos a leitura do artigo integral foi feita com essa finalidade. A análise completa por número de artigos e porcentagem está nas Tabelas 22 a 27, nas páginas 73 a 74 . Gostaríamos de destacar aqui alguns dados:

Tabela 32 - TOTAL DE ARTIGOS POR TEMAS CONSIDERANDO TODO O CORPUS

\begin{tabular}{|c|c|c|}
\hline Temas & $\begin{array}{c}\text { Número total } \\
\text { de artigos }\end{array}$ & \% do total \\
\hline Epistemologia e Teorias da Comunicação & 113 & $9 \%$ \\
\hline Comunicação audiovisual, imagética e sonora & 291 & $23,2 \%$ \\
\hline Tecnologias da Comunicação & 182 & $14,6 \%$ \\
\hline Comunicação jornalística & 201 & $16 \%$ \\
\hline Comunicação em publicidade e propaganda & 30 & $2,4 \%$ \\
\hline Comunicação organizacional & 19 & $1,5 \%$ \\
\hline Comunicação e produção editorial & 13 & $1 \%$ \\
\hline Comunicação e processos de recepção, de & 75 & $6 \%$ \\
\hline interação e de consumo & 148 & $11,8 \%$ \\
\hline Comunicação nas dinâmicas socioculturais & 181 & $14,5 \%$ \\
\hline Comunicação e interfaces disciplinares & 1253 & $100 \%$ \\
\hline Total & & \\
\hline
\end{tabular}


Capítulo 5 - Discussão - O autor brasileiro nos periódicos científicos Quem são, temas e referências bibliográficas preponderantes

Tabela 33 (Extraída das Tabelas 23 A 27) -

OS TEMAS MAIS RECORRENTES NOS CINCO PERIÓDICOS

\begin{tabular}{|c|c|c|c|c|c|}
\hline \multirow{2}{*}{ Temas } & \multicolumn{4}{|c|}{ Porcentagem dos temas mais recorrentes por periódico } \\
\cline { 2 - 6 } & E-Compós & Famecos & Galáxia & Intercom & MATRIZes \\
\hline $\begin{array}{c}\text { Epistemologia } \\
\text { e Teorias da } \\
\text { Comunicação (A) }\end{array}$ & $\mathbf{2 5 \%}$ & $17,85 \%$ & $\mathbf{3 9} \%$ & $13,22 \%$ & $\mathbf{2 7 , 2} \%$ \\
\hline $\begin{array}{c}\text { Comunicação } \\
\text { audiovisual, } \\
\text { imagética e sonora } \\
\text { (B) }\end{array}$ & $\mathbf{2 5 , 7 2 \%}$ & $13,57 \%$ & & $15,6 \%$ \\
\hline $\begin{array}{c}\text { Tecnologias da } \\
\text { Comunicação (C) }\end{array}$ & $15,4 \%$ & $17,6 \%$ & $\mathbf{2 7} \%$ & \\
\hline $\begin{array}{c}\text { Comunicação } \\
\text { jornalística (D) }\end{array}$ & $22 \%$ & $17,85 \%$ & 14,47 & & $13 \%$ \\
\hline $\begin{array}{c}\text { Comunicação } \\
\text { nas dinâmicas } \\
\text { socioculturais (I) }\end{array}$ & $13,46 \%$ & & & \\
\hline $\begin{array}{c}\text { Comunicação } \\
\text { e interfaces } \\
\text { disciplinares (J) }\end{array}$ & $18 \%$ & & \\
\hline
\end{tabular}

Algumas considerações:

- O tema Comunicação audiovisual, imagética e sonora foi o mais encontrado em três dos cinco periódicos, chegando a 39\% dos artigos em Galáxia, pouco mais de $27 \%$ em MATRIZes e $25 \%$ em E-Compós. Foi, no âmbito geral, o tema mais abordado no total geral de artigos do corpus, com 23,2\%. São estudos, em sua maioria, sobre os meios: predominantemente ${ }^{52}$ cinema e televisão e alguns poucos sobre rádio. Entraram ainda nessa categoria os estudos sobre fotografia, embora não sejam numerosos.

- Ainda que todos os periódicos tenham artigos com o tema Epistemologia e Teorias da Comunicação, apenas em Intercom e MATRIZes o assunto é o segundo mais recorrente.

- Tecnologias da Comunicação foi o tema mais abordado em Famecos, embora não tão à frente de Comunicação audiovisual, imagética e sonora e Comunicação e interfaces disciplinares. Apareceu ainda como tema importante para Galáxia

52. Os estudos sobre jornais e revistas foram classificados na categoria D, de Comunicação Jornalística - se juntássemos os dois temas, sem dúvida os estudos de midiologia seriam os mais numerosos também em Famecos e Intercom. Ou seja, podemos afirmar que os estudos de midiologia são os mais numerosos em todo o corpus. 
e MATRIZes. Dentro desse tema, predominam os estudos sobre cibernética e possibilidades da internet dentro da Comunicação.

- Comunicação jornalística foi o tema predominante em Intercom, com $27 \%$ dos artigos. O periódico, mais antigo do corpus, nasceu nos anos 1980, em que o Jornalismo ainda era a especialização mais bem estabelecida na área de Comunicação e, portanto, firmou-se a tradição de publicar os estudos sobre jornalismo nesse periódico. O tema também é significativo em Famecos e Galáxia, periódicos publicados por programas de pós-graduação de universidades que oferecem a graduação em Jornalismo. Em MATRIZes, no entanto, publicada pela USP, que também teve o curso de Jornalismo como pioneiro na Escola de Comunicação e Artes, o tema aparece apenas em quinto lugar.

- Comunicação nas dinâmicas socioculturais é o segundo tema mais recorrente em E-Compós, bastante representado por estudos sobre práticas culturais de comunidades contemporâneas. Não teve grande representatividade nos demais periódicos.

- Comunicação e interfaces disciplinares é o terceiro tema mais recorrente nos periódicos E-Compós e Galáxia, o segundo em Famecos (empatado com Comunicação audiovisual, imagética e sonora) e o quarto em MATRIZes. Em Galáxia, se tomássemos como análise seus três primeiros anos de publicação (de 2001 a 2004), esse tema seria ainda mais significativo, já que o periódico nasceu em um programa de pós-graduação em Comunicação e Semiótica, sendo esta a disciplina que mais aparecia nos artigos. No entanto, ao longo dos anos, observou-se que Galáxia ampliou seu escopo e diminuiu o número de edições com grande número de estudos semióticos e passou a acolher outros temas, como visto anteriormente. Curiosamente, Comunicação e interfaces disciplinares não tem relevância na Revista da Intercom - Sociedade Brasileira de Estudos Interdisciplinares da Comunicação, aparecendo apenas como $5^{\circ}$ tema mais relevante, com $8,5 \%$ dos artigos, apesar do termo interdisciplinar no nome da Sociedade e da Revista.

Além dos temas com maior número de artigos, as ausências também falam muito a respeito dos periódicos e da pesquisa em Comunicação.

- Comunicação organizacional e Comunicação e produção editorial são os temas com menos artigos nas revistas, conforme mostra a Tabela 34, a seguir. São também esses os temas menos abordados no geral de artigos, com 1\% apenas do total (produção editorial) e 1,5\% (organizacional), conforme Tabela 32, na página 82. 
Capítulo 5 - Discussão - O autor brasileiro nos periódicos científicos Quem são, temas e referências bibliográficas preponderantes

Tabela 34 - TEMAS MENOS RECORRENTES NOS PERIÓDICOS

\begin{tabular}{|c|c|c|c|c|c|}
\hline \multirow{2}{*}{ Temas } & \multicolumn{5}{|c|}{ Revistas } \\
\cline { 2 - 6 } & E-Compós & Famecos & Galáxia & Intercom & MATRIZes \\
\hline $\begin{array}{c}\text { Comunicação } \\
\text { organizacional (F) }\end{array}$ & 0,65 & $2,4^{53}$ & 0 & 3,17 & 0 \\
\hline $\begin{array}{c}\text { Comunicaçãa } \\
\text { e produção } \\
\text { editorial (G) }\end{array}$ & 1,28 & 0,44 & 1,35 & 0,55 & 3,9 \\
\hline
\end{tabular}

Não é possível afirmar com segurança os motivos da pouca representatividade desses assuntos, uma vez que sabemos que pesquisas com esses temas têm sido realizadas de forma sistemática. A própria Intercom possui Grupos de Pesquisa (GP) em Relações Públicas e Comunicação Organizacional, bem como de Produção Editorial, cujo crescimento no número de trabalhos apresentados em congressos da Sociedade Brasileira de Estudos Interdisciplinares da Comunicação é notório. MATRIZes, da USP, também não tem um único artigo publicado em Comunicação organizacional entre 2007 e 2012, sendo que a Escola de Comunicações e Artes possui um núcleo forte, coordenado por lideranças da área, como a Profa. Dra. Margarida Maria Krohling Kunsch que, inclusive, faz parte do conselho editorial do periódico. Neste caso, a explicação pode estar no fato de que as pesquisas em Comunicação Organizacional têm periódicos de nichos, como a Revista Organicom (Revista Brasileira de Comunicação Organizacional e Relações Públicas), cuja presidente é a própria Profa. Dra. Margarida e é apenas uma das publicações da Abrapcorp (Associação Brasileira de Pesquisadores de Comunicação Organizacional e Relações Públicas).

No caso de Produção Editorial, é fato que o maior congresso que reúne os pesquisadores da área é realmente o da Intercom, porém há núcleos bem estabelecidos de pesquisa especialmente na UFRGS e na USP. Cada uma dessas universidades também possuem publicações. No caso da UFRGS, a Intexto e a Em Questão $0^{54}$, ambas do programa de pós-graduação em Comunicação e Informação. Na USP, o Núcleo de Estudos do Livro e da Edição (NELE), da ECA, ligada ao curso de Editoração, publica a revista Livro.

53. O segundo tema menos recorrente em Famecos e MATRIZes é Comunicação em Publicidade e Propaganda, com $2 \%$ e $1,3 \%$ respectivamente.

54. O periódico Em Questão acolhia, até 2014, artigos de Comunicação e Informação, mas restringiu para artigos de Informação. A revista Intexto aceita apenas artigos de Comunicação. 
Os temas Comunicação em publicidade e propaganda e Comunicação e processos de recepção, de interação e de consumo também apareceram nos periódicos não como temas predominantes, porém com representatividade crescente.

\subsection{QUEM É O PESQUISADOR BRASILEIRO}

Analisados os dados, se fizermos uma extrapolação a partir das maiores porcentagens, podemos responder ao título desta tese sobre quem é o pesquisador brasileiro nos periódicos científicos de Ciências da Comunicação. Com base nos dados levantados, podemos afirmar que o perfil predominante de autor brasileiro que publica nos periódicos nacionais mais bem avaliados em Ciências da Comunicação é mulher ( $52,3 \%$ dos autores), doutora (37,8\% do total de autores, conforme Tabela 10, na página 66), escreve sozinha (77\%, conforme Tabela 12, na página 67), sem coautores e é filiada à USP. O tema predominante são os estudos em midiologia.

\subsection{AUTORES MAIS CITADOS NAS REFERÊNCIAS BIBLIOGRÁFICAS DE ARTIGOS DE PESQUISADORES BRASILEIROS}

Ao traçar o perfil predominante do autor brasileiro nos periódicos A2 em Ciências da Comunicação, decidimos dar mais um passo e analisar quem esse autor cita em seus trabalhos.

A citação é uma prática utilizada na produção de textos científicos que tem como função primária correlacionar dois textos. Como ferramenta dos estudos bibliométricos, a Análise de Citações (AC) permite relacionar o citante com o citado, mostrando as fontes que o primeiro utilizou para produzir seu trabalho. Embora apresente limitações, a análise de citações pode contribuir para entender a estrutura e o desenvolvimento de uma ciência, bem como as regularidades do comportamento dos cientistas no uso de fontes de informação (PRIMO et al, 2008: 1).

Ao citar, o autor do artigo "arregimenta amigos", como define ironicamente Latour (2000: 55), mostra de onde veio, quais suas origens e seus estudos, utilizando-se sempre de autores legitimados em seu campo (ou em campos correlatos, como no caso da Comunicação, de formação transdisciplinar), aqueles que possuem capital científico (BOURDIEU, 1983: 123). Ainda segundo Latour (Ibid: 58), o texto científico não é jamais um texto isolado, capaz "de se opor à opinião das multidões por virtude de alguma misteriosa faculdade", mas o que o torna 
Capítulo 5 - Discussão - O autor brasileiro nos periódicos científicos Quem são, temas e referências bibliográficas preponderantes

científico é quando há numerosas pessoas engajadas e estão indicadas explicitamente no texto, tornando-o mais difícil de ser contestado. "Uma monografia sem referências é como uma criança desacompanhada a caminhar pela noite de uma grande cidade que ela não conhece: isolada, perdida, pode acontecer-lhe qualquer coisa" (LATOUR, 2000, 58-59).

Analisemos, então, as companhias científicas dos autores brasileiros dos periódicos A2 (e também as ausências).

O número de referências bibliográficas encontradas foi de 2406 nos 125 artigos analisados, uma média de 19 referências citadas por artigo. O dado é similar ao encontrado no trabalho de Primo et al (2008), ao analisar os trabalhos submetidos ao congresso da Compós em 2008, de 17,6 referências por artigo (de um universo de 2111 referências em 120 artigos). No entanto, se olharmos entre os periódicos do corpus, a diferença varia bastante. Do menor para o maior, foram uma média de 16,3 referências citadas em artigos da Galáxia, para 24,8 em MATRIZes.

Encontramos, em Famecos e em Intercom um trabalho em cada que contava com apenas uma referência e, em Famecos, um artigo com 68 referências listadas, conforme mostra a tabela 35 .

Tabela 35 - ESTATÍSTICAS DO NÚMERO DE CITAÇÕES POR ARTIGO DAS REVISTAS SELECIONADAS

\begin{tabular}{|c|c|c|c|c|}
\hline Revista & N & Mínimo & Máximo & Média \\
\hline Todos & 146 & 1 & 68 & 19 \\
\hline E-Compós & 31 & 6 & 44 & 20,5 \\
\hline Famecos & 45 & 1 & 68 & 18,5 \\
\hline Galáxia & 22 & 4 & 38 & 16,3 \\
\hline Intercom & 19 & 1 & 53 & 18,3 \\
\hline MATRIZes & 8 & 6 & 60 & 24,8 \\
\hline
\end{tabular}

Já a tabela 36 mostra os 25 autores mais citados nos artigos do corpus, de um total de 1500 autores citados (de 2406 obras, sejam elas livros ou artigos). 
Pesquisadores brasileiros em Periódicos Científicos de Ciências da Comunicação

Tabela 36 - AUTORES MAIS CITADOS

\begin{tabular}{|c|c|c|c|c|c|c|c|c|c|c|c|c|c|}
\hline \multirow{2}{*}{ Posição } & \multirow{2}{*}{ Autor } & \multicolumn{2}{|c|}{ E-Compós } & \multicolumn{2}{|c|}{ Famecos } & \multicolumn{2}{|c|}{ Galáxia } & \multicolumn{2}{|c|}{ Intercom } & \multicolumn{2}{|c|}{ MATRIZes } & \multicolumn{2}{|c|}{ Total } \\
\hline & & $\mathrm{N}$ & $\%$ & $\mathbf{N}$ & $\%$ & $\mathbf{N}$ & $\%$ & $\mathbf{N}$ & $\%$ & $\mathbf{N}$ & $\%$ & $\mathbf{N}$ & $\%$ \\
\hline 1 & FOUCAULT, M & 8 & 20 & 12 & 30 & 13 & 32,5 & 2 & 5 & 5 & 12,5 & 40 & 100 \\
\hline 2 & BAUDRILLARD, J & 11 & 31,4 & 16 & 45,7 & 1 & 2,9 & 3 & 8,6 & 4 & 11,4 & 35 & 100 \\
\hline 3 & MELO, J M DE & 2 & 6,9 & 6 & 20,7 & 0 & 0 & 12 & 41,4 & 9 & 31 & 29 & 100 \\
\hline 4 & MAFFESOLI, M & 2 & 7,4 & 18 & 66,7 & 4 & 14,8 & 2 & 7,4 & 1 & 3,7 & 27 & 100 \\
\hline 5 & CASTELLS, M & 7 & 35 & 4 & 20 & 1 & 5 & 3 & 15 & 5 & 25 & 20 & 100 \\
\hline 6 & DELEUZE, G & 7 & 35 & 5 & 25 & 6 & 30 & 1 & 5 & 1 & 5 & 20 & 100 \\
\hline 7 & BARTHES, R & 4 & 21,1 & 10 & 52,6 & 3 & 15,8 & 0 & 0 & 2 & 10,5 & 19 & 100 \\
\hline 8 & FREIRE, $P$ & 1 & 5,2 & 1 & 5,3 & 0 & 0 & 17 & 89,5 & 0 & 0 & 19 & 100 \\
\hline 9 & LÉVY, P & 6 & 35,3 & 4 & 23,5 & 2 & 11,8 & 3 & 17,6 & 2 & 11,8 & 17 & 100 \\
\hline 10 & BOURDIEU, P & 1 & 6,2 & 3 & 18,8 & 1 & 6,2 & 3 & 18,8 & 8 & 50 & 16 & 100 \\
\hline 11 & FLUSSER, V & 6 & 37,5 & 3 & 18,8 & 4 & 25 & 2 & 12,5 & 1 & 6,2 & 16 & 100 \\
\hline 12 & MORIN, E & 8 & 50,1 & 5 & 31,2 & 0 & 0 & 2 & 12,5 & 1 & 6,2 & 16 & 100 \\
\hline 13 & RANCIÈRE, J & 1 & 6,3 & 2 & 12,5 & 13 & 81,2 & 0 & 0 & 0 & 0 & 16 & 100 \\
\hline 14 & MARTÍN-BARBERO, J & 6 & 37,5 & 0 & 0 & 1 & 6,2 & 3 & 18,8 & 6 & 37,5 & 16 & 100 \\
\hline 15 & SODRÉ, M & 4 & 28,6 & 2 & 14,3 & 0 & 0 & 0 & 0 & 8 & 57,1 & 14 & 100 \\
\hline 16 & VIRILIO, P & 3 & 21,4 & 6 & 42,9 & 0 & 0 & 1 & 7,1 & 4 & 28,6 & 14 & 100 \\
\hline 17 & BAKHTIN, M & 4 & 33,3 & 0 & 0 & 2 & 16,7 & 4 & 33,3 & 2 & 16,7 & 12 & 100 \\
\hline 18 & HABERMAS, J & 3 & 25 & 3 & 25 & 3 & 25 & 2 & 16,7 & 1 & 8,3 & 12 & 100 \\
\hline 19 & HALL, S & 6 & 49,9 & 2 & 16,7 & 2 & 16,7 & 0 & 0 & 2 & 16,7 & 12 & 100 \\
\hline 20 & LEMOS, A & 0 & 0,1 & 7 & 58,3 & 0 & 0 & 1 & 8,3 & 4 & 33,3 & 12 & 100 \\
\hline 21 & MARTINEZ, J L & 0 & 0 & 0 & 0 & 12 & 100 & 0 & 0 & 0 & 0 & 12 & 100 \\
\hline 22 & GARCÍA-CANCLINI, N & 5 & 41,7 & 1 & 8,3 & 0 & 0 & 4 & 33,4 & 2 & 16,6 & 12 & 100 \\
\hline 23 & VERÓN, E & 5 & 45,4 & 2 & 18,2 & 1 & 9,1 & 0 & 0 & 3 & 27,3 & 11 & 100 \\
\hline 24 & VIZER, EA & 0 & 0 & 11 & 100 & 0 & 0 & 0 & 0 & 0 & 0 & 11 & 100 \\
\hline 25 & BAUMAN, Z & 5 & 50 & 4 & 40 & 0 & 0 & 0 & 0 & 1 & 10 & 10 & 100 \\
\hline 26 & BOLAÑO, C & 0 & 0 & 0 & 0 & 0 & 0 & 10 & 100 & 0 & 0 & 10 & 100 \\
\hline 27 & DEBORD, G & 4 & 40 & 2 & 20 & 0 & 0 & 2 & 20 & 2 & 20 & 10 & 100 \\
\hline 28 & FAUSTO NETO, A & 4 & 40 & 3 & 30 & 0 & 0 & 0 & 0 & 3 & 30 & 10 & 100 \\
\hline 29 & MARCONDES FILHO, C & 2 & 20 & 5 & 50 & 0 & 0 & 1 & 10 & 2 & 20 & 10 & 100 \\
\hline 30 & SANTAELLA, L & 0 & 0 & 0 & 0 & 4 & 40 & 0 & 0 & 6 & 60 & 10 & 100 \\
\hline 31 & SANTOS, M & 1 & 10 & 4 & 40 & 0 & 0 & 1 & 10 & 4 & 40 & 10 & 100 \\
\hline 32 & TRAQUINA, N & 1 & 10 & 2 & 20 & 1 & 10 & 6 & 60 & 0 & 0 & 10 & 100 \\
\hline
\end{tabular}


Capítulo 5 - Discussão - O autor brasileiro nos periódicos científicos Quem são, temas e referências bibliográficas preponderantes

É preciso atentar para alguns autores da lista: Michel Maffesoli (posição 4), Paulo Freire (posição 8), José Martinez (posição 20), Eduardo Vizer (posição 22), Cesar Bolaño (posição 24). O primeiro, das 27 citações recebidas, 18 vieram apenas de FAMECOS. Paulo Freire, das 19 citações, 17 vieram da Intercom e, olhando as listas completas, de apenas um artigo. Os demais autores, todos, também foram citados em um mesmo periódico.

Podemos afirmar com segurança que os autores mais citados são europeus, a maioria composta por filósofos franceses, reafirmando a grande influência desses pensadores nas Ciências Sociais brasileiras.

Dos brasileiros, além dos já citados acima, queremos destacar José Marques de Melo, Muniz Sodré, André Lemos, Antonio Fausto Neto, Ciro Marcondes Filhos e Lucia Santaella, todos pesquisadores e professores da área de Comunicação (e citados em mais de um periódico). Apenas Milton Santos não é originário da área de Comunicação.

Da América do Sul, aparecem Jesús Martín-Barbero, Néstor García-Canclini e Eliseo Verón. Dos Estados Unidos, o primeiro autor é John B. Thompson, com nove referências. Em relação ao trabalho de Primo et al (2008), o resultado em relação aos europeus e sul-americanos é bastante parecido, porém não em relação aos brasileiros, que tiveram maior representatividade no outro trabalho. No mesmo trabalho de Primo et al, é feita uma comparação com os resultados obtidos a partir dos artigos da Compós com o trabalho de Samile Vanz ${ }^{55}$, de 2004, que analisou 100 dissertações defendidas nos cursos de pós-graduação em Comunicação da UFRGS, PUCRS e Unisinos. O resultado é muito interessante. "As duas listas apresentam os mesmos 16 autores nas primeiras 30 posições" (Ibid.: 16). Da lista de nosso trabalho, dos 31 autores, apenas 11 não aparecem nos outros dois trabalhos citados. Os autores são: Paulo Freire, Vilém Flusser, Jacques Rancière, Jürgen Habermas, Eduardo A. Vizer, César Bolaño, Milton Santos, Nelson Traquina, André Lemos, José Luiz Martinez e Guy Debord. No comparativo com o trabalho de Richard Romancini (2006), que analisou as teses e dissertações dos programas de pós-graduação em Comunicação de 2004, todos os autores estrangeiros encontrados na nossa lista dos mais citados também estão ali presentes.

A tabela 37 mostra as obras (textos, livros e artigos) mais citados nos periódicos do corpus.

55. VANZ, Samile Andréa Souza. A produção discente em comunicação: análise das citações das dissertações defendidas nos programas de pós-graduação do Rio Grande do Sul. 2004. Dissertação - UFRGS, 2004. 
Pesquisadores brasileiros em Periódicos Científicos de Ciências da Comunicação

Tabela 37 - TEXTOS MAIS CITADOS NAS REFERÊNCIAS BIBLIOGRÁFICAS

\begin{tabular}{|c|c|c|c|c|c|c|c|c|c|c|c|c|}
\hline \multirow{2}{*}{ Nome do artigo } & \multicolumn{2}{|c|}{ E-Compós } & \multicolumn{2}{|c|}{ Famecos } & \multicolumn{2}{|c|}{ Galáxia } & \multicolumn{2}{|c|}{ Intercom } & \multicolumn{2}{|c|}{ MATRIZes } & \multicolumn{2}{|c|}{ Total } \\
\hline & $\mathbf{N}$ & $\%$ & $\mathbf{N}$ & $\%$ & $\mathrm{~N}$ & $\%$ & $\mathbf{N}$ & $\%$ & $\mathbf{N}$ & $\%$ & $\mathbf{N}$ & $\%$ \\
\hline $\begin{array}{l}\text { A sociedade em rede - } \\
\text { Manuel Castells }\end{array}$ & 4 & 33,3 & 2 & 17 & 1 & 8,3 & 2 & 17 & 3 & 25 & 12 & 100 \\
\hline $\begin{array}{c}\text { A sociedade do espetáculo - } \\
\text { Guy Debord }\end{array}$ & 4 & 40 & 2 & 20 & 0 & 0 & 2 & 20 & 2 & 20 & 10 & 100 \\
\hline Cibercultura - Pierre Lévy & 3 & 37,5 & 2 & 25 & 0 & 0 & 1 & 12 & 2 & 25 & 8 & 100 \\
\hline $\begin{array}{c}\text { A Contemplação do Mundo - } \\
\text { Michel' Maffesoli }\end{array}$ & 1 & 14,3 & 4 & 57 & 1 & 14,3 & 1 & 14 & 0 & 0 & 7 & 100 \\
\hline $\begin{array}{l}\text { A realidade dos meios } \\
\text { de comunicação - } \\
\text { Niklas Luhmann }\end{array}$ & 1 & 16,7 & 2 & 33 & 0 & 0 & 1 & 17 & 2 & 33 & 6 & 100 \\
\hline $\begin{array}{c}\text { Antropologica do Espelho - } \\
\text { Muniz Sodré }\end{array}$ & 2 & 33,3 & 1 & 17 & 0 & 0 & 0 & 0 & 3 & 50 & 6 & 100 \\
\hline Conversações - Gilles Deleuze & 3 & 50 & 3 & 50 & 0 & 0 & 0 & 0 & 0 & 0 & 6 & 100 \\
\hline $\begin{array}{c}\text { Mil Platos - Gilles Deleuze } \\
\text { e Félix Guattari }\end{array}$ & 1 & 16,6 & 1 & 17 & 1 & 16,7 & 1 & 17 & 2 & 33 & 6 & 100 \\
\hline $\begin{array}{l}\text { Simulacros e simulação - } \\
\text { Jean Baudrillard }\end{array}$ & 3 & 49,9 & 1 & 17 & 0 & 0 & 1 & 17 & 1 & 17 & 6 & 100 \\
\hline Vigiar e Punir - Michel Foucault & 3 & 49,9 & 1 & 17 & 1 & 16,7 & 0 & 0 & 1 & 17 & 6 & 100 \\
\hline $\begin{array}{c}\text { Condição Pós-Moderna - } \\
\text { David Harvey }\end{array}$ & 2 & 40 & 1 & 20 & 0 & 0 & 1 & 20 & 1 & 20 & 5 & 100 \\
\hline $\begin{array}{l}\text { Dos meios às mediações - } \\
\text { Jesús Martín-Barbero }\end{array}$ & 2 & 40 & 0 & 0 & 1 & 20 & 0 & 0 & 2 & 40 & 5 & 100 \\
\hline $\begin{array}{l}\text { Ideologia e cultura moderna, } \\
\text { Teoria social crítica na era dos } \\
\text { meios de comunicação de massa } \\
\text { - John B. Thompson }\end{array}$ & 1 & 20 & 1 & 20 & 0 & 0 & 2 & 40 & 1 & 20 & 5 & 100 \\
\hline $\begin{array}{c}\text { Modernidade Líquida - Zygmunt } \\
\text { Bauman }\end{array}$ & 2 & 40 & 2 & 40 & 0 & 0 & 0 & 0 & 1 & 20 & 5 & 100 \\
\hline
\end{tabular}

Novamente, as obras são, em sua maioria, dos autores europeus e, todas, no formato livro. A única obra de autor brasileiro é Antropológica do Espelho, de Muniz Sodré. Na tabela de autores, José Marques de Melo é o mais citado, porém ele aparece com 23 obras, o que acabou por pulverizar a participação de cada uma. Muniz Sodré aparece com sete obras. O mesmo pode-se dizer em relação à posição de Michel Foucault, que aparece com 25 obras. No entanto, entre as mais citadas, está apenas Vigiar e Punir.

Podemos ainda observar que a maior parte das obras entraria, no que podemos chamar, de maneira geral, como obras filosóficas e, as mais específicas ao campo, referem-se aos meios - o que corresponde ao achado desta pesquisa de que a maior parte dos estudos são feitos em midialogia. 
Capítulo 5 - Discussão - O autor brasileiro nos periódicos científicos Quem são, temas e referências bibliográficas preponderantes

Por essa lista de obras podemos também perceber o quão pulverizadas são as referências utilizadas nos artigos analisados do corpus. A obra mais citada recebeu apenas 12 citações. Ou seja, os artigos dos periódicos trazem poucas referências a obras consideradas referência pelo campo. Se não há essa unidade, por outro lado, podemos positivamente destacar que a Comunicação é um campo aberto a contribuições, o que mostra uma renovação em contribuições de obras e autores. No entanto, o hábito de citar artigos nas referências ainda é bastante restrito cerca de apenas $20 \%$ das citações.

\subsection{CONSIDERAÇÕES FINAIS}

Retomando as hipóteses formuladas no início da pesquisa para este trabalho, podemos formular algumas considerações a respeito:

- A primeira delas era de que os periódicos científicos do corpus têm alta exigência quanto à titulação de seus autores, portanto os pesquisadores encontrados seriam, em sua maioria, doutores, e a maior parte dos trabalhos, escritos individualmente.

Essa hipótese foi confirmada, de maneira geral, e o índice da presença de doutores variou entre o máximo de 62,3\% em MATRIZes a 58\% em E-Compós e Intercom, como já explicado anteriormente. No entanto, surpreendeu a presença de um artigo de graduando em Galáxia, já que é uma revista de um programa de pós-graduação e a exigência mínima para publicação é de que o pesquisador seja, no mínimo, doutorando. Também confirmou-se que a maior parte dos trabalhos é escrita por um único autor, reforçando a tradição do campo.

- A segunda hipótese é de que a publicação de autores ainda é regionalizada, principalmente nas revistas de programas de pós-graduação.

Essa hipótese também se confirmou, posto que a maioria dos artigos publicados em Famecos é, essencialmente da PUC RS, instituição que publica o periódico, mas também há um índice grande de publicações da UFRGS, do mesmo estado, sendo que esta universidade não tem tanto destaque em número de artigos nos demais periódicos do corpus. Da mesma maneira, a maioria dos artigos de MATRIZes são de pesquisadores da própria USP, seguida por duas instituições do Sudeste, a UFRJ e a PUC-SP. Em Galáxia também predominam os trabalhos da USP e PUC-SP, ambas da capital paulista, e da UFRJ.

Além de nossas hipóteses, podemos ainda concluir que a maior parte dos artigos volta-se para os estudos dos meios, reafirmando uma inclinação dos pesquisadores para os meios como objeto das Ciências da Comunicação, embora um periódico jovem como MATRIZes pareça apontar uma resistência (ou o emergir 
de uma forte corrente) ao ter Epistemologia e Teorias da Comunicação como o seu segundo tema com maior número de publicações, assim como a Revista Intercom, embora esta seja a mais antiga do corpus. Uma análise de conteúdo mais profunda, que analisasse os artigos por completo talvez pudesse apontar o nascimento da tão desejada união de estudos que permitam formulações teóricas com as pesquisas das práticas dentro da área de Comunicação, assunto ainda bastante em discussão em congressos e palestras como um alvo a ser alcançado pelo campo.

Da parte de análise das referências bibliográficas, podemos salientar que, embora os autores - especialmente os estrangeiros - sejam os mesmos recorrentes neste trabalho, assim como em outros citados anteriormente, o campo tem uma bibliografia muito vasta, com citações bastante pulverizadas. O que pode indicar uma abertura do campo a novos autores e textos, mas também indica que não há uma (ou algumas) linha(s) de pensadores fundadores seguida(s) pelo pesquisadores do campo.

Acreditamos que este trabalho possa ser usado por outros pesquisadores para fazerem outras perguntas ao estudar nossas planilhas e tabelas.

Além dos ajustes necessários a fim de publicar artigos decorrentes desta tese, pretendemos continuar o trabalho analisando os autores estrangeiros que publicam nos periódicos do corpus e seus temas de interesse. 


\section{REFERÊNCIAS BIBLIOGRÁFICAS}

BARBOSA, Marialva. História da Comunicação no Brasil. Petrópolis: Vozes, 2013.

Comunicação: consolidação de uma interdisciplinar como paradigma de construção do campo comunicacional. In.: Anais ALAIC - GT 17 - Teorias y Metodologias de la investigación en Comunicación, 2000.

BARRADAS, Maria Mércia. Prefácio. In.: FERREIRA, Sueli M. S. P.; TARGINO, Maria das Graças (org.). Preparação de revistas científicas: teoria e prática. São Paulo: Reichmann \& Autores, 2005.

BEIRA, Eduardo. Inovação e concorrência em serviços de informação acadêmica: de Eugene Garfield ao Google Scholar. Encontros Bibli: revista eletrônica de biblioteconomia e ciência da informação, Florianópolis, p. 132-163, nov. 2010. ISSN 1518-2924. Disponível em: <https://periodicos.ufsc.br/index.php/ eb/article/view/16593/15767>. Acesso em: 30 Abr. 2015. doi:http://dx.doi. org/10.5007/1518-2924.2010v15nesp2p132.

BERELSON, Bernard. Graduate education in the United States. New York: McGrawHill, 1960.

BRAGANÇA, Aníbal. Eros pedagógico. A função editor e a função autor. Tese de doutorado. São Paulo: Escola de Comunicações e Artes (ECA) da Universidade de São Paulo (USP), 2001.

BOURDIEU, Pierre. O campo científico. In.: ORTIZ, Renato (org.) Pierre Bourdieu - sociologia. São Paulo: Ática, 1983

Sobre a televisão. Rio de Janeiro: Jorge Zahar, 1997. 
Referências Bibliográficas

O poder simbólico. Rio de Janeiro: Bertrand Brasil, 2010.

; CHAMBOREDON, Jean Claude; PASSERON, Jean Claude. A profissão de Sociólogo: preliminares epistemológicas. 2. ed. Petrópolis: Vozes, 1999. BUSSAB, W.O. e MORETTIN, P.A. Estatística Básica. São Paulo: Ed. Saraiva, 6. Ed, 2006.

CASTRO, Regina Célia F.; FERREIRA, Maria Cecília Gonzaga; VIDILI, Ana Lucia. Periódicos Latino-Americanos: avaliação das características formais e sua relação com a qualidade científica. Ciência da Informação, [S.1.], v. 25, n. 3, Dez. 1996. ISSN 1518-8353. Disponível em: <http://revista.ibict.br/index.php/ ciinf/article/view/459/418>. Acesso em março 2015.

CERVO, Amado L.; BERVIAN, Pedro A. Metodologia científica. 4. ed. São Paulo: Makron Books, 1996

CHARTIER, Roger. A aventura do livro - do leitor ao navegador. São Paulo: Editora Unesp/Imprensa Oficial, 2009.

DARNTON, Robert. A questão dos livros. São Paulo: Companhia das Letras, 2010.

; ROCHE, Daniel. Revolução impressa - A imprensa na França (1775-180o). São Paulo: Edusp, 1996.

DELGADO, Emilio \& REPISO, Rafael. The Impact of Scientific Journals of Communication: Comparing Google Scholar Metrics, Web of Science and Scopus [El impacto de las revistas de comunicación: comparando Google Scholar Metrics, Web of Science y Scopus]. Comunicar, 41, 45-52. Huelva: Grupo Comunicar, 2013. DOI: 10.3916/C41-2013-04.

FERREIRA, Sueli Mara P. et al. Estudo sobre como autores de artigos de revistas de Ciências da Comunicação verbalizam seus objetos de estudos em termos de palavras-chave. In.: Em Questão. Porto Alegre, v. 15 n. 2, p.151-167. Jul/Dez 2009.

; TARGINO, Maria das Graças. Preparação de revistas científicas. São Paulo: Reichmann \& Autores, 2005.

FORTES, Rafael. Revistas. In: ENCICLOPÉDIA Intercom de Comunicação - São Paulo: Sociedade Brasileira de Estudos Interdisciplinares da Comunicação, 2010. Vol. 1

GRUSZYNSKI, Ana, GOLIN, Cida e CASTEDO, Raquel. Produção editorial e comunicação científica: uma proposta para edição de revistas científicas. In: Revista da Associação Nacional dos Programas de Pós-Graduação em Comunicação - E-Compós. Brasília, v. 11, n. 2, maio/agosto 2008. 
JACSO, Peter. As we may search - Comparison of major features of the Web of Science, Scopus and Google Scholar citation-based and citation-enhanced databases. In.: Current Science, v. 89, n.9, p. 1537-1547, nov. 2005. http://choo. fis.utoronto.ca/FIS/courses/LIS1325/Readings/jacso.pdf Acesso em jan. 2015

LEFEBVRE, Muriel. L'évaluation des savoirs scientifiques: modalités et enjeux. In: Schöpfel, J. (Org.). La publication scientifique : analyses et perspectives. Paris: Hermès, 2008.

LOPES, Maria Immacolata Vassallo de. Pesquisa em Comunicação. São Paulo: Edições Loyola, 2005, $8^{\text {a }}$ Ed.

Sobre o estatuto disciplinar do campo da Comunicação. In.: LOPES, Maria Immacolata V. de. Epistemologia da Comunicação. São Paulo: Edições Loyola, 2003.

MAGNONÍ, Antonio Francisco e MIRANDA, Giovani Vieira. Novas formas de Comunicação no século XXI: o fenômeno da cultura participativa. In.: Conexão - Comunicação e Cultura, UCS, Caxias do Sul. v. 12, n.23, jan/jun.2013 pp.103-120

MARTINO, Luiz C. As epistemologias contemporâneas e o lugar da Comunicação. In.: LOPES, Maria Immacolata V. de. Epistemologia da Comunicação. São Paulo: Edições Loyola, 2003.

Interdisciplinaridade e objeto de estudo da Comunicação. In.: HOHLFELDT, Antonio; MARTINO, Luiz C. e FRANÇA, Vera V. Teorias da Comunicação: Conceitos, escolas e tendências. $3^{\text {a }}$ ed. Petrópolis: Editora Vozes, 2003 (a)

MEADOWS, Arthur Jack. A comunicação científica. Brasília: Briquet de Lemos/ Livros, 1999.

MELO, José Marques de. História do pensamento comunicacional. São Paulo: Paulus, 2007. $2^{\mathrm{a}} \mathrm{ed}$.

. Paradigmas da escola latino-americana de comunicação. In.: Comunicação \& Informação. V. 2. N.2 p. 188-203, jul/dez. 1999. http://www.revistas.ufg. br/index.php/ci/article/viewFile/22854/13595 http://dx.doi.org/10.5216/CEI. V2I2.22854 Acesso em abril 2015.

MIĖGE, Bernard. O pensamento comunicacional. Petrópolis: Vozes, 2000.

MORAIS, Osvando J. de (org.). Ciências da comunicação em processo: paradigmas e mudanças nas pesquisas em comunicação no século XXI: conhecimento, leituras e práticas contemporâneas. São Paulo: INTERCOM, 2014. 
Referências Bibliográficas

OHIRA, M. de L. B. Periódicos brasileiros especializados em Biblioteconomia e Ciência da Informação: evolução. Encontros Bibli: Revista Eletrônica de Biblioteconomia e Ciência da Informação. Florianópolis, n. 10, out. 2000. Disponível em <http://www.periodicos.ufsc.br/index.php/eb/article/view/16>. Acesso em nov. 2010.

PRIMO, Alex et al. Análises de citações dos trabalhos da Compós 2008. In.: Revista da Associação Nacional dos Programas de Pós-Graduação em Comunicação E-Compós. Pp. 1-19. Brasilia, v. 11, n.3, set. dez. 2008

R Core Team. $R$ : A language and environment for statistical computing. R Foundation for Statistical Computing, Vienna, Austria, 2014. ISBN 3-900051-07-0, URL http://www.R-project.org/.

ROMANCINI, Richard. Tese O campo científico da Comunicação no Brasil: institucionalização e capital científico. 2006. TESE v. 1

SCHAFF, Adam. História e verdade. São Paulo: Martins Fontes, 1978.

STUMPF, Ida R. C. Avaliação das revistas de Comunicação pela comunidade acadêmica da área. Em Questão: Revista da Faculdade de Biblioteconomia e Comunicação da UFRGS. Porto Alegre: v. 9, n. 1, p. 25-38, jan./jun.2003. Disponível em <http://seer.ufrgs.br/index.php/EmQuestao/article/view/57/17>. Acesso em nov. 2010.

Passado e futuro das revistas científicas. Ciência da Informação. Brasília, dez. 1996. Disponível em <http://revista.ibict.br/index.php/ciinf/article/ view/463/422>. Acesso em nov. 2010.

TARGINO, Maria das Graças. Comunicação científica na sociedade tecnológica: periódicos eletrônicos em discussão. In.: Revista Comunicação e Sociedade. n. 31. Pág. 71 a 98. São Bernardo do Campo: Editora Metodista, 1998.

THOMAZ, Petronio Generoso; ASSAD, Renato Samy; MOREIRA, Luiz Felipe P.. Uso do Fator de impacto e do índice $\mathrm{H}$ para avaliar pesquisadores e publicações. Arq. Bras. Cardiol., São Paulo, v. 96, n. 2, p. 90-93, Fev. 2011 . Disponível em $<$ http://www.scielo.br/scielo.php?script=sci_arttext\&pid=Soo66-782X201100 0200001\&lng=en\&nrm=iso $>$. Acesso em maio 2015. http://dx.doi.org/10.159o/ Soo66-782X2011000200001.

THOMPSON, John B. Books in the digital age. Malden, EUA: Polity Press, 2005.

TRZESNIAK, Piotr. As dimensões da qualidade dos periódicos científicos e sua presença em um instrumento da área da Educação. In.: Revista Brasileira de Educação. Maio/agosto, ano 11, n. 32. São Paulo: Associação Nacional de PósGraduação e Pesquisa em Educação, 2006. Pp. 346-361 


\section{Referências Bibliográficas}

\section{Endereços eletrônicos consultados}

E-Compós - http://www.compos.org.br/seer/index.php/e-compos/

Famecos - http://revistaseletronicas.pucrs.br/ojs/index.php/revistafamecos

Galáxia - http://revistas.pucsp.br/index.php/galaxia

Intercom - http://www.intercom.org.br/revista

MATRIZes - http://www.matrizes.usp.br

Qualis - http://qualis.capes.gov.br/

Scielo - http://www.scielo.br 


\section{Anexos}

\section{ANEXO 1}

\section{LISTA DOS PERIÓDICOS DE CIÊNCIAS DA COMUNICAÇÃO (TRIÊNIO 2010-2012) PELO WEBQUALIS (B1 A B5)}

\begin{tabular}{|l|c|c|}
\hline \multicolumn{1}{|c|}{ Revistas } & Estrato & Instituição \\
\hline Ação midiática & B3 & UFPR \\
\hline Alceu & B1 & PUC-Rio \\
\hline Animus & B1 & UFSM \\
\hline Apontamentos midiáticos & B5 & UFAL \\
\hline Aurora & B4 & PUC SP \\
\hline Brazilian Journalism Research & B1 & SBPJOR \\
\hline Cadernos de Comunicação & B4 & UFSM \\
\hline Caligrama & B1 & USP \\
\hline Cambiassu & B4 & UFMA \\
\hline Cenários da comunicação & B5 & Uninove \\
\hline Ciberlegenda & B1 & UFF \\
\hline Cinema caipira & B5 & Grupo Kino Olho \\
\hline ComCiência & B4 & UNICAMP \\
\hline Comum & B5 & FACHA - Faculdades Integradas \\
\hline Communicare & B2 & Facasper \\
\hline $\begin{array}{l}\text { Comunicação: Reflexões, Experiências, } \\
\text { Ensino }\end{array}$ & B4 & Universidade Positivo \\
\hline Comunicação e Educação & B2 & USP \\
\hline Comunicação \& Estratégia & B5 & Prof. Wilson Bueno \\
\hline
\end{tabular}


Anexo 1

\begin{tabular}{|c|c|c|}
\hline Revistas & Estrato & Instituição \\
\hline Comunicação \& Mercado & B4 & Unigram \\
\hline Comunicação \& Política & B2 & UFRGS \\
\hline Comunicação e Sociedade & $\mathrm{B} 1$ & Umesp \\
\hline Comunicação, mídia e consumo & $\mathrm{Bl}$ & ESPM \\
\hline Comunicação Veredas & B3 & UNIMAR \\
\hline Comunicarte & B3 & UniBH \\
\hline Comunicologia & B3 & BRASILIA \\
\hline Conexão & $\mathrm{Bl}$ & UCS \\
\hline Conexões midiáticas & B5 & UFPB \\
\hline Contemporânea & $\mathrm{Bl}$ & UFBA \\
\hline Contracampo & B1 & UFF \\
\hline Culturas mediáticas & B1 & UFPB \\
\hline Cultura visual & $\mathrm{Bl}$ & UFBA \\
\hline Devires & $\mathrm{Bl}$ & UFMG \\
\hline Discursos fotográficos & $\mathrm{Bl}$ & UEL \\
\hline Dispositiva & B4 & PUC-Minas \\
\hline ECCOM & B1 & $\begin{array}{c}\text { Fatea - Faculdades Integradas } \\
\text { Teresa D'Ávila }\end{array}$ \\
\hline E-com & B5 & UniBH \\
\hline ECO-PÓS & B1 & UFRGS \\
\hline Ecos & B3 & UFF \\
\hline Ecos & B3 & UNEMAT \\
\hline Em questão & B1 & UFRGS \\
\hline Entremeios & B5 & PUC-Rio \\
\hline Esferas & B4 & $\begin{array}{c}\text { Pós em Comunicação do Centro } \\
\text { Oeste }\end{array}$ \\
\hline Estudos de jornalismo e relações públicas & B4 & Umesp \\
\hline Estudos em Design & B2 & PUC-Rio \\
\hline Filosofia da Mídia & B5 & \\
\hline Revista Eptic & B1 & Alaic/Intercom \\
\hline Espcom & B4 & UFMG \\
\hline Estudos em jornalismo e mídia & B1 & UFSC \\
\hline Facom & B4 & Faap \\
\hline Heterotopias & B5 & Faculdade 7 de setembro- $\mathrm{CE}$ \\
\hline Ícone & B4 & UFPE \\
\hline Inovcom & B5 & Intercom/Unimar \\
\hline
\end{tabular}


Anexo 1

\begin{tabular}{|c|c|c|}
\hline Revistas & Estrato & Instituị̧ão \\
\hline Interface & B1 & UNESP BOTUCATU \\
\hline Interin & B1 & UTP \\
\hline Intexto & B1 & UFRGS \\
\hline Líbero & $\mathrm{Bl}$ & FACASPER \\
\hline Linguagens & B5 & FURB \\
\hline Livro & B5 & USP \\
\hline Logos & B1 & UERJ \\
\hline Lugar comum & B4 & UFRJ \\
\hline Lumina & B1 & UFJF \\
\hline Mediação & B3 & FUMEC \\
\hline Mídia e política & B5 & UNB \\
\hline Novos Olhares & B2 & USP \\
\hline Organicom & B1 & USP \\
\hline Comunicação mediática & $\mathrm{Bl}$ & UNESP \\
\hline Revista Alterjor & B2 & USP \\
\hline Rebeca & B4 & Socine \\
\hline REBEJ & B3 & FNPJ \\
\hline Revista Anagrama & B5 & USP \\
\hline Revista Brasileira de História da Mídia & B3 & $\begin{array}{l}\text { Rede Brasileira de Pesquisadores } \\
\text { de História da Mídia }\end{array}$ \\
\hline $\begin{array}{l}\text { Revista Brasileira de Políticas de } \\
\text { Comunicação }\end{array}$ & B5 & UnB \\
\hline Revista Contemporânea & B5 & UERJ \\
\hline Revista de Comunicação e cultura & B4 & UCS \\
\hline Revista de Estudos da Comunicação & B3 & PUC-PR \\
\hline Revistas de Estudos de Jornalismo & B5 & PUC-Campinas \\
\hline $\begin{array}{l}\text { Revista Eletrônica do Programa de Pós- } \\
\text { Graduação em Mídia e Cotidiano }\end{array}$ & B4 & UFF \\
\hline Revista Extraprensa & $\mathrm{B} 1$ & USP \\
\hline Revista Fronteiras & $\mathrm{B} 1$ & Unisinos \\
\hline Revista Geminis & B2 & UFSCAR \\
\hline Revista Internacional de Folkcomunicação & B3 & UEPG \\
\hline Revista Laika & B4 & USP \\
\hline Revista Mediação & B4 & Fumec \\
\hline Revista Pensar Comunicação & B5 & Faculdades Promove \\
\hline Revista Universitas & B3 & UNICEUB \\
\hline RUA - Revista Universitária do Audiovisual & B3 & UFSCAR \\
\hline
\end{tabular}


Anexo 1

\begin{tabular}{|l|c|c|}
\hline \multicolumn{1}{|c|}{ Revistas } & Estrato & Instituição \\
\hline Rumores & B1 & USP \\
\hline Sala Preta & B4 & USP \\
\hline Semeiosis & B2 & USP \\
\hline Sessões do imaginário & B1 & PUCRS \\
\hline Significação & B1 & USP \\
\hline Signos do consumo & B2 & USP \\
\hline Teorema & B3 & PORTO ALEGRE \\
\hline Textos de cultura e comunicação & B4 & UFBA \\
\hline Verso e reverso & B2 & UNISINOS \\
\hline Vozes e diálogo & B3 & UNIVALI \\
\hline
\end{tabular}

Fonte: WebQualis 


\section{ANEXO 2}

Revista MATRIZes - Índice h por Google Scholar Metrics (calculado pelo Google Scholar em junho 2014) e disponível em https://scholar.google. com.br/citations?view_op=top_venues\&hl=pt-BR\&vq=pt (Acesso em maio 2015)

\begin{tabular}{|c|c|c|}
\hline Publicação & Índice h5 & Mediana h5 \\
\hline MATRIZes & 11 & 16 \\
\hline
\end{tabular}

Índice $\mathrm{h}_{5}$ - $\mathrm{O}$ índice $\mathrm{h}_{5}$ é o indexador $\mathrm{h}$ dos artigos publicados nos últimos cinco anos passados. Trata-se do maior número $h$ de uma publicação, em que h artigos publicados de 2009 a 2013 tenham sido citados no mínimo h vezes cada. No caso de MATRIZes, 11 artigos foram citados, no mínimo, 11 vezes cada (considerando os últimos 5 anos)

A mediana $\mathbf{h}_{5}$ de uma publicação consiste na média de citações para os artigos que compõem seu índice h5. No caso de MATRIZes, a média de citações por artigo foi de 16 vezes, conforme a seguir 
Anexo 2

\begin{tabular}{|c|c|c|c|}
\hline Título & Autor & $\begin{array}{c}\text { Citado por } x \\
\text { trabalhos, sendo } x=\end{array}$ & $\begin{array}{l}\text { Ano de } \\
\text { publicação } \\
\text { do artigo }\end{array}$ \\
\hline $\begin{array}{c}\text { Telenovela como recurso } \\
\text { comunicativo }\end{array}$ & MIV Lopes & 31 & 2010 \\
\hline $\begin{array}{l}\text { Redes sociais e os estudos de } \\
\text { recepção na internet }\end{array}$ & $\begin{array}{c}\text { D Cogo, L Dutra } \\
\text { Brignol }\end{array}$ & 24 & 2011 \\
\hline Uma aventura epistemológica & J Martín-Barbero & 20 & 2009 \\
\hline $\begin{array}{c}\text { As novas narrativas da ficção } \\
\text { televisiva e a Internet }\end{array}$ & C Lacalle & 19 & 2010 \\
\hline $\begin{array}{c}\text { Políticas culturais e novos } \\
\text { desafios }\end{array}$ & AAC Rubim & 16 & 2009 \\
\hline $\begin{array}{c}\text { Nem rara, nem ausente } \\
\text { - tentativa }\end{array}$ & JL Braga & 16 & 2010 \\
\hline $\begin{array}{l}\text { Visibilidade mediática, } \\
\text { melancolia do único e } \\
\text { violência invisível na } \\
\text { cibercultura }\end{array}$ & ER Trivinho & 12 & 2011 \\
\hline $\begin{array}{l}\text { Convocação nas revistas e } \\
\text { construção do "a mais" nos } \\
\text { dispositivos midiáticos }\end{array}$ & JLA Prado & 11 & 2010 \\
\hline $\begin{array}{c}\text { Internet literacy: a negociação } \\
\text { dos jovens com as novas } \\
\text { oportunidades on-line }\end{array}$ & S Livingstone & 11 & 2012 \\
\hline $\begin{array}{l}\text { Digitalizados por decreto. } \\
\text { Cibercultur@: inclusão } \\
\text { forçada na América Latina }\end{array}$ & JA Gonzaléz & 11 & 2009 \\
\hline O docudrama televisivo & V Fuenzalida & 11 & 2009 \\
\hline
\end{tabular}

Total de citações: 182

Total de artigos: 11

Então Mediana h - 16,54 


\section{ANEXO 3}

\begin{tabular}{|c|c|c|c|c|c|}
\hline \multirow{2}{*}{ Tiłulação do aułor } & \multicolumn{5}{|c|}{ Número de artigos por revista } \\
\hline & E-Compós & Famecos & Galáxia & Intercom & MATRIZes \\
\hline Doutor & 134 & 3 & 98 & 72 & 40 \\
\hline Doutorando & 46 & 3 & 26 & 19 & 5 \\
\hline Mestre & 9 & 0 & 0 & 5 & 0 \\
\hline Mestrando & 12 & 0 & 0 & 1 & 0 \\
\hline Graduado & 0 & 0 & 0 & 7 & 0 \\
\hline Um autor sem especificação & 29 & 360 & 52 & 26 & 20 \\
\hline Ambos autores sem especificação & 2 & $32[8]$ & 0 & $3[14]$ & 0 \\
\hline $\begin{array}{l}1^{\circ} \text { autor não especificado; } \\
2^{\circ} \text { autor DR }\end{array}$ & 2 & 1 & 1 & 0 & 0 \\
\hline $\begin{array}{l}1^{\circ} \text { autor não especificado; } \\
2^{\circ} \text { autor doutorando }\end{array}$ & 0 & 11 & & 0 & 1 \\
\hline $\begin{array}{l}1^{\circ} \text { autor não especificado; } \\
2^{\circ} \text { autor mestre }\end{array}$ & 0 & 6 & & 0 & 0 \\
\hline $\begin{array}{l}1^{\circ} \text { autor não especificado; } \\
2^{\circ} \text { autor mestrando }\end{array}$ & 1 & 15 & $2[13]$ & 0 & 1 \\
\hline $\begin{array}{l}1^{\circ} \text { autor não especificado; } \\
2^{\circ} \text { autor graduado }\end{array}$ & 0 & 9 & & 0 & 0 \\
\hline $\begin{array}{l}1^{\circ} \text { autor não especificado; } \\
2^{\circ} \text { autor graduando }\end{array}$ & 1 & $1[9]$ & & 2 & 0 \\
\hline $\begin{array}{l}1^{\circ} \text { autor não especificado; } \\
6 \text { coautores graduandos }\end{array}$ & 1 & & & 0 & \\
\hline $\begin{array}{l}1^{\circ} \text { autor não especificado; } \\
2^{\circ} \text { mestrando; } 3^{\circ} \text { autor graduado }\end{array}$ & 1 & 0 & & 0 & 0 \\
\hline $\begin{array}{l}1^{\circ} \text { autor não especificado; } \\
2^{\circ} \text { mestrando; } 3^{\circ} \text { autor graduando }\end{array}$ & 1 & 0 & & 0 & 0 \\
\hline $\begin{array}{l}1^{\circ} \text { e } 2^{\circ} \text { autores não especificados, } \\
3^{\circ} \text { autor doutorando }\end{array}$ & 1 & 0 & & 0 & 0 \\
\hline $\begin{array}{l}1^{\circ} \text { e } 2^{\circ} \text { autores não especificados, } \\
3^{\circ} \text { autor mestrando }\end{array}$ & 1 & 0 & & 0 & 0 \\
\hline $\begin{array}{l}1^{\circ} \text { e } 2^{\circ} \text { autores não especificados, } \\
3^{\circ} \text { autor graduando }\end{array}$ & 1 [2] & 1 & & 1 & 0 \\
\hline
\end{tabular}


Anexo 2

\begin{tabular}{|c|c|c|c|c|c|}
\hline Tiłulação do aułor & \multicolumn{5}{|c|}{ Número de artigos por revista } \\
\hline $\begin{array}{l}1^{\circ} \text { autor doutor e } 2^{\circ} \text { autor não } \\
\text { especificado }\end{array}$ & 0 & 1 & 1 & 0 & 0 \\
\hline Autor e coautor doutores & $14[3]$ & 1 & $14[11]$ & 10 & 2 \\
\hline Autor dr; coautor doutorando & 6 & 0 & 6 & 4 & 4 \\
\hline Autor $\mathrm{dr}$; coautor mestre & 3 & 0 & 2 & 5 & 1 \\
\hline Autor dr; coautor mestrando & $8[4]$ & 0 & 4 & 4 & 1 \\
\hline Autor dr; coautor graduado & $1[5]$ & 0 & 1 & 3 & 0 \\
\hline Autor dr; coautor graduando & $9[6]$ & 0 & 2 & 6 & 0 \\
\hline Autor doutorando; coautor doutor & 4 & 0 & 2 & 3 & 1 \\
\hline Autor e coautor doutorandos & 1 & 0 & 2 & 0 & 0 \\
\hline $\begin{array}{l}\text { Autor doutorando e coautor } \\
\text { mestrando }\end{array}$ & 3 & 0 & 0 & 0 & 0 \\
\hline $\begin{array}{l}1^{\circ} \text { autor doutorando; } 2^{\circ} \text { autor } \\
\text { doutor; } 3^{\circ} \text { autor doutorando }\end{array}$ & 1 & 1 & 0 & 0 & 0 \\
\hline $\begin{array}{l}1^{\circ} \text { autor doutorando; } 2^{\circ} \text { autor } \\
\text { graduando; } 3^{\circ} \text { autor doutor }\end{array}$ & 1 & 0 & 0 & 0 & 0 \\
\hline $\begin{array}{l}1^{\circ} \text { autor doutorando; } 2^{\circ} \text { autor } \\
\text { mestre; } 3^{\circ} \text { autor doutor }\end{array}$ & 1 & 0 & 0 & 0 & 0 \\
\hline $\begin{array}{l}\text { Autor doutorando e coautor não } \\
\text { especificado }\end{array}$ & 2 & 4 & 2 & 0 & 0 \\
\hline Autor mestre; coautor doutor & 6 & 0 & 0 & 5 & 0 \\
\hline Autor e coautor mestre & 1 & 0 & 0 & 0 & 0 \\
\hline Autor mestre e coautor mestrando & 0 & 0 & 0 & 0 & 0 \\
\hline $\begin{array}{l}\text { Autor mestre e coautor não } \\
\text { especificado }\end{array}$ & 0 & 1 & 1 & 2 & 0 \\
\hline Autor mestrando e coautor doutor & 3 & 0 & 2 & 1 & 0 \\
\hline $\begin{array}{l}\text { Autor mestrando e coautor não } \\
\text { especificado }\end{array}$ & 0 & 1 & 0 & 0 & 0 \\
\hline Autor graduado e coautor doutor & 0 & 0 & 0 & 1 & 0 \\
\hline Autor graduando; coautor $\mathrm{dr}$ & 0 & 0 & 1 & 0 & 0 \\
\hline SOMA DOIS AUTORES - N.3 & 12 & 6 & 6 & 9 & 0 \\
\hline Outros & 6 [7] & $3[10]$ & $2[12]$ & $9[15]$ & $1[16]$ \\
\hline
\end{tabular}

[2] $1^{\circ}$ e $2^{\circ}$ autores não especificados e 3 coautores graduandos.

[3] 1 dos artigos é assinado por 4 autores doutores.

[4] Um dos artigos é assinado por um doutor e dois mestrandos.

[5] Artigo assinado por um doutor e 4 graduados.

[6] Desses 9, 2 são assinados por $1^{\circ}$ autor doutor e dois coautores graduandos.

[7] Um artigo assinado por dois doutores e um coautor mestrando; um artigo assinado por dois doutores e dois mestrandos; um artigo assinado por dois doutores, três mestres e um mestrando; três artigos assinado por um doutor; um mestrando e um graduando.

[8] Desses, três artigos têm 3 autores não especificados.

[9] Primeiro autor não especificado; segundo autor graduando; demais autores graduado e graduando [10]Um artigo com dois doutorandos e um não especificado; um artigo $1^{\circ}$ autor doutorando e outros dois não identificados; um artigo com dois autores não especificados e um mestrando com não especificado; um artigo com mestre e coautor não especificado; um artigo $1^{\circ}$ autor doutorando e outros dois não identificados. 
Anexo 2

[11] Dois artigos com 3 doutores.

[12] Um artigo $1^{\circ}$ autor não especificado, coautores 1 doutorando, 1 mestre e 2 mestrandos; um artigo $1^{\circ}$ autor dr; coautores mestre, doutor e mestrando.

[13] Um dos artigos com $1^{\circ}$ autor não especificado e dois coautores mestrandos; um artigo com $1^{\circ}$ autor doutor, coautores mestre, doutor e mestrando; um artigo com $1^{\circ}$ autor graduando e coautor doutor.

[14] Em dois dos artigos são 3 autores não especificados.

[15] Um artigo com $1^{\circ}$ autor não especificado e dois coautores graduandos; um artigo com $1^{\circ}$ autor não identificado e coautores um mestre e um doutorando; um artigo $1^{\circ}$ autor doutor; coautores doutorando e graduado; um artigo $1^{\circ}$ e $2^{\circ}$ autores doutores e outro mestrando; um artigo $1^{\circ}$ e $2^{\circ}$ autores doutores e outro mestre; um artigo $1^{\circ}$ autor doutor, um graduado e um mestre; um artigo $1^{\circ}$ autor doutor e dois graduandos; um artigo $1^{\circ}$ e $2^{\circ}$ autores mestrandos e um terceiro doutor; um artigo mestre, não especificado, graduado e graduado.

[16] Um artigo $1^{\circ}$ autor não especificado, coautores um doutorando e um mestre 


\section{ANEXO 4}

Autores principais encontrados na análise do corpus ( $\mathrm{x}$ indica ao menos um artigo publicado no periódico correspondente).

\begin{tabular}{|c|c|c|c|c|c|}
\hline Autores & E-Compós & Famecos & Galáxia & Intercom & MATRIZes \\
\hline Ada Cristina Machado da Silveira & & & & $\mathrm{x}$ & $\mathrm{x}$ \\
\hline Ada de Freitas Maneti Dencker & & & & $x$ & \\
\hline Ademilde Silveira Sartori & $x$ & $x$ & & & \\
\hline Adilson Citelli & & & & & $x$ \\
\hline Adilson Vaz Cabral Filho & $x$ & & & $x$ & \\
\hline Adolpho Queiroz & & $x$ & & & \\
\hline Adriana Amaral & $\mathrm{x}$ & $x$ & & & \\
\hline Adriana Braga & $x$ & $x$ & & & \\
\hline Adriana Schryver Kurtz & $x$ & & & & \\
\hline Adriana Stürmer & & & $x$ & & \\
\hline Adriano Warken Floriani & & $x$ & & & \\
\hline Afonso de Albuquerque & $x$ & $x$ & & $\mathrm{x}$ & \\
\hline Alarcon Agra do Ó & & $x$ & & & \\
\hline Alberto Efendy Maldonado & & & & $x$ & \\
\hline Alberto Klein & $x$ & $x$ & & & \\
\hline Alessandra Aldé & & $x$ & & & \\
\hline Aletéia Ferreira & $x$ & & & & \\
\hline Alex Fernando Teixeira Primo & $x$ & $\mathrm{x}$ & $x$ & & $\mathrm{x}$ \\
\hline Alex Galeno & & $x$ & & & \\
\hline Alexandra Bujokas de Siqueira & & & & $x$ & \\
\hline Alexandre Barbalho - 2 vezes & & & & $x$ & \\
\hline Alexandre Rocha da Silva & & $x$ & $x$ & $x$ & \\
\hline $\begin{array}{l}\text { Alexandre S. Kieling e GT de Estudos } \\
\text { de Televisão }\end{array}$ & & $x$ & & & \\
\hline Alfredo Eurico Vizeu Pereira Junior & $x$ & $x$ & & $x$ & \\
\hline Aline Silva Correa Maia & $x$ & & & & \\
\hline Almir Rosa & & & $x$ & & \\
\hline
\end{tabular}


Anexo 4

Autores

E-Compós Famecos Galáxia Intercom MATRIZes

\begin{tabular}{|c|c|c|c|c|c|}
\hline Álvaro Nunes Laranjeira & $x$ & $x$ & & & \\
\hline Ana Carolina D. Escosteguy & $x$ & $x$ & $x$ & & \\
\hline Ana Carolina Rocha Pessoa Temer & & & & $x$ & \\
\hline Ana Carolina Vimieiro & $x$ & $x$ & & & \\
\hline Ana Claudia de Oliveira & & & $x$ & & \\
\hline Ana Claudia Gruszynski & $x$ & & & & \\
\hline Ana Elisa Antunes Viviani & $x$ & & & & \\
\hline Ana Lucia S. Enne & $x$ & & $x$ & $x$ & \\
\hline Ana Luíza Cerbino & & & & $x$ & \\
\hline Ana Luiza Coiro Moraes & & $\mathrm{x}$ & & & \\
\hline Ana Maria D. Zilocchi & & & $x$ & & \\
\hline Ana Paula Goulart Ribeiro & & & & $x$ & \\
\hline Ana Regina Rego & & & & $x$ & \\
\hline Ana Silvia Lopes Davi Médola & $x$ & & & $x$ & $\mathrm{x}$ \\
\hline Ana Taís Martins Portanova Barros & $\mathrm{x}$ & $x$ & $x$ & $x$ & \\
\hline André Azevedo da Fonseca & & & & $x$ & \\
\hline André Brasil & & $x$ & $\mathrm{x}$ & & \\
\hline André Lemos & $x$ & $\mathrm{x}$ & $x$ & $x$ & $\mathrm{x}$ \\
\hline André Parente & & $x$ & $x$ & & \\
\hline André Queiroz & & $x$ & & & \\
\hline André Sathler Guimarães & & $x$ & & $x$ & \\
\hline Andréa França & & $x$ & & $x$ & $x$ \\
\hline Ângela Cristina Salgueiro Marques & $x$ & $x$ & $x$ & & \\
\hline Ângela Cristina Trevisan Felippi & & $x$ & & & \\
\hline Angela Pintor dos Reis & $x$ & & & & \\
\hline Angela Prysthon & $x$ & $x$ & $x$ & & \\
\hline Ângela Teixeira Moraes & & & & $x$ & \\
\hline Angela Zamin & & & $x$ & & \\
\hline Angie Bondi & & $\mathrm{x}$ & & & \\
\hline Aníbal Bragança & & & & & $x$ \\
\hline Anita Leandro & $x$ & & & & \\
\hline Antonia Zago & $x$ & & & & \\
\hline Antonio Adami & $x$ & & & & \\
\hline Antonio Albino Canelas Rubim & & & $x$ & $\mathrm{x}$ & $\mathrm{x}$ \\
\hline Antonio Brasil & & $x$ & & & \\
\hline Antônio Fausto Neto & & $x$ & $x$ & $x$ & $x$ \\
\hline Antonio Hohlfeldt & $x$ & $x$ & & $x$ & \\
\hline Antonio Pacca Fatorelli & & & $\mathrm{x}$ & & \\
\hline Antônio Risério & & & $x$ & & \\
\hline
\end{tabular}


Anexo 4

\begin{tabular}{|c|c|c|c|c|c|}
\hline Autores & E-Compós & Famecos & Galáxia & Intercom & MATRIZes \\
\hline Ariane Diniz Holzbach & $\mathrm{x}$ & & $\mathrm{x}$ & & \\
\hline Arlindo Machado & $x$ & $x$ & $x$ & & $x$ \\
\hline Armindo Bião & & $x$ & & & \\
\hline Arquimedes Pessoni & & & & $x$ & \\
\hline Arthur Autran & & $x$ & & & \\
\hline Austriclínio Bezerra de Andrade Neto & & & & $x$ & \\
\hline Beatriz Becker & & $x$ & $x$ & & $x$ \\
\hline Beatriz Bretas & $x$ & & & & \\
\hline Beatriz Dornelles & $x$ & $x$ & & & \\
\hline Beatriz Jaguaribe & & $x$ & $x$ & & \\
\hline Beatriz Marocco & & & $\mathrm{x}$ & & \\
\hline Benjamim Picado & $\mathrm{x}$ & $x$ & $x$ & & $x$ \\
\hline Bernardette Lyra & $\mathrm{x}$ & & & & \\
\hline Betania Maciel & & & & $\mathrm{x}$ & \\
\hline Bianca Freire-Medeiros & $x$ & & & & \\
\hline Bráulio de Britto Neves & & & $x$ & & \\
\hline Bruno Campanella & $x$ & & & & \\
\hline Bruno Costa & $\mathrm{x}$ & & $\mathrm{x}$ & & \\
\hline Bruno Souza Leal & $x$ & $x$ & $x$ & $x$ & \\
\hline Carla Baiense Felix & & & $\mathrm{x}$ & & \\
\hline Carla Luciana Silva & & & & $x$ & \\
\hline Carla Rodrigues & & & $x$ & & \\
\hline Carlos Alberto de Carvalho & $x$ & $x$ & & & $x$ \\
\hline Carlos Alexandre de Carvalho Moreno & & & & $x$ & \\
\hline Carlos Eduardo Marquioni & & & & $x$ & \\
\hline Carlos Gerbase & $x$ & $x$ & & & \\
\hline Carlos Magno Camargo Mendonça & & $x$ & $x$ & & \\
\hline Carolina Dantas de Figueiredo & $\mathrm{x}$ & & & & \\
\hline Carolina Rodrigues Paz & & $x$ & & & \\
\hline Carolina Sá-Carvalho & & & $x$ & & \\
\hline Caroline Casali & $x$ & & & & \\
\hline Cassio dos Santos Tomaim & & $x$ & & $x$ & \\
\hline Cecília de Almeida Salles & & & $x$ & & \\
\hline Celso Frederico & & & & & $\mathrm{x}$ \\
\hline Celso Vitelli & & $\mathrm{x}$ & & & \\
\hline César Bolaño & $x$ & & & $x$ & \\
\hline César Geraldo Guimarães & $x$ & & $x$ & & \\
\hline César Pessoa Pimentel & $\mathrm{x}$ & & & & \\
\hline Charbel Niño El-Hani & & & $x$ & & \\
\hline
\end{tabular}


Anexo 4

\section{Autores}

E-Compós famecos Galáxia Infercom MATRIZes

\begin{tabular}{|c|c|c|c|c|c|}
\hline Christa Berger & & $x$ & & & \\
\hline Christine Ferreira Azzi & & & $x$ & & \\
\hline Cicilia M. Krohling Peruzzo & & $x$ & $x$ & $x$ & \\
\hline Cida Golin & & $x$ & & & \\
\hline Cíntia Dal Bello & $x$ & & & & \\
\hline Ciro Marcondes Filho & & $x$ & $x$ & & $x$ \\
\hline Clara Ávila Ornellas & & $x$ & & & \\
\hline Clarissa Castiglione & & & & $\mathrm{x}$ & \\
\hline Cláudia da Silva Pereira & & $x$ & & & \\
\hline Claudia Irene de Bastos & & & $x$ & & \\
\hline Claudia Irene de Quadros & $x$ & $x$ & & & \\
\hline Claudia Jurberg & & & & $x$ & \\
\hline Cláudia Peixoto de Moura & & $x$ & & & \\
\hline Cláudia Pereira & & $x$ & & & \\
\hline Claudio Bertolli Filho & $x$ & & & & \\
\hline Claudio Cardoso de Paiva & & $x$ & & & \\
\hline Clélio Estevão Thomaz & & & & $x$ & \\
\hline Cleusa Maria A. de Scroferneker & $x$ & $x$ & & & \\
\hline Cleuza G. Gimenes Cesca & & $x$ & & & \\
\hline Clóvis de Barros Filho & & $x$ & & & \\
\hline Clóvis Reis & & & & $x$ & \\
\hline Clóvis Ricardo Montenegro de Lima & & $x$ & & & \\
\hline Consuelo Lins & & & $\mathrm{x}$ & & \\
\hline Cremilda Medina & & & & & $x$ \\
\hline Cristiane Finger & & $x$ & & & \\
\hline Cristiane Freitas Gutfreind & $x$ & $x$ & & & \\
\hline Cristiane Hengler Corrêa Bernardo & & & & $x$ & \\
\hline Cristiane Mafacioli Carvalho & & $x$ & & & \\
\hline Cristiano Henrique Ribeiro dos Santos & $x$ & & & & \\
\hline Cristina Brandão & & $x$ & & & \\
\hline Cristina Ennes da Silva & & & & $x$ & \\
\hline Cristina Pontes Bonfiglioli & $x$ & & & & \\
\hline Cristina Teixeira Vieira de Melo & $x$ & & & & \\
\hline Cristovão Domingos de Almeida & & $x$ & & & \\
\hline Cynthia Harumi Watanabe Corrêa & $x$ & & & & \\
\hline Daniela Santiago & $\mathrm{x}$ & & & & \\
\hline Daniela Zanetti & $x$ & & & & $\mathrm{x}$ \\
\hline Daniella Ramos Silva & $x$ & & & & \\
\hline Danielle Ramos Brasiliense & $x$ & & & & \\
\hline
\end{tabular}


Anexo 4

\begin{tabular}{|c|c|c|c|c|c|}
\hline Autores & E-Compós & Famecos & Galáxia & Intercom & MATRIZes \\
\hline Danilo Fraga & $\mathrm{x}$ & & & & \\
\hline Danilo Rothberg & & & & $x$ & \\
\hline Débora Cristina Lopez & & & & & $x$ \\
\hline Debora Cristine Rocha & $x$ & & & & \\
\hline Débora de Carvalho Pereira & & & $x$ & & \\
\hline Denilson Lopes & $x$ & & & & \\
\hline Denise Azevedo Duarte Guimarães & $x$ & $x$ & & $x$ & $x$ \\
\hline Denise Cogo & & & & $x$ & $x$ \\
\hline Denize Correa Araujo & $x$ & & & & \\
\hline Diego Andres Salcedo & $\mathrm{x}$ & & & & \\
\hline Diego Gouveia Moreira & & & $\mathrm{x}$ & & \\
\hline Dimas A. Kunsch & & $x$ & & & \\
\hline Dora Kaufman & & & $\mathrm{x}$ & & \\
\hline Doris Fagundes Haussen & $x$ & $x$ & & & \\
\hline Dulci Boettcher & & $x$ & & & \\
\hline Dulcilia H. Schroeder Buitoni & & & $x$ & & \\
\hline Ecio P. de Salles & $\mathrm{x}$ & & & & \\
\hline Edgard Rebouças & & & & $x$ & \\
\hline Edilson Cazeloto & & $x$ & $x$ & & $x$ \\
\hline Edson Dalmonte & & $x$ & $\mathrm{x}$ & $x$ & $x$ \\
\hline Eduardo A. Vizer & & $\mathrm{x}$ & & & \\
\hline Eduardo Campos Pellanda & $x$ & & & & \\
\hline Eduardo Duarte Gomes da Silva & & & $x$ & & \\
\hline Eduardo Granja Coutinho & $\mathrm{x}$ & & & & \\
\hline Eduardo Meditsch & & & & $x$ & \\
\hline Eduardo Morettin & & $x$ & $x$ & & \\
\hline Eduardo Natário & $x$ & & & & \\
\hline Eduardo Nunes Freire & & & $x$ & & \\
\hline Eduardo Peñuela Canizal & & $x$ & $x$ & & \\
\hline Eduardo Vicente & $x$ & & & & \\
\hline Egle Müller Spinelli & & & $x$ & & \\
\hline Elaine Caramella & & & $x$ & & \\
\hline Elane Peixoto & $x$ & & & & \\
\hline Elias de Pádua Monteiro & & & & $x$ & \\
\hline Elias Machado & $x$ & & & & \\
\hline Elisa de Sousa Martinez & & & $x$ & & \\
\hline Elisa Reinhardi Piedras & $x$ & & & $\mathrm{x}$ & \\
\hline Elizabeth Bastos Duarte & $x$ & & & & \\
\hline Elizabeth Moraes Gonçalves & $x$ & $x$ & & & \\
\hline
\end{tabular}


Anexo 4

Autores

E-Compós Famecos Galóxia Intercom MATRIZes

\begin{tabular}{|c|c|c|c|c|c|}
\hline Elizabeth Saad Correa & & & & & $x$ \\
\hline Elton Antunes & & & $x$ & & \\
\hline Emerson Urizzi Cervi & & $x$ & & & \\
\hline Eneus Trindade & & & & $x$ & $\mathrm{x}$ \\
\hline Erick Felinto & $x$ & $x$ & $x$ & $x$ & $x$ \\
\hline Ernani Cesar de Freitas & & & & $x$ & \\
\hline Eron Brum & & & & $x$ & \\
\hline Eugenia Mariano da Rocha Barichello & $x$ & & & & \\
\hline Eugênio Trivinho & $x$ & $x$ & $x$ & & $x$ \\
\hline Eugênio Bucci & & & & & $x$ \\
\hline Euler David de Siqueira & & & & $\mathrm{x}$ & \\
\hline Everton Terres Cardoso & & & $x$ & & \\
\hline Fabio B. Josgrillberg & & $x$ & & $x$ & \\
\hline Fábio Duarte & & & $x$ & & \\
\hline Fábio Fonseca de Castro & & $\mathrm{x}$ & & & \\
\hline Fábio Henrique Pereira & & & & $x$ & \\
\hline Fabio Luiz Carneiro Mourilhe Silva & & & & $x$ & \\
\hline Fábio Malini & $x$ & & & & \\
\hline Fábio SouzA DA Cruz & & $x$ & & & \\
\hline Fabrício Silveira & $x$ & & $x$ & & \\
\hline Fátima Régis de Oliveira & $x$ & $x$ & & $x$ & \\
\hline Felipe da Costa Trotta & $x$ & $x$ & $x$ & & \\
\hline Felipe Muanis & & & $x$ & & \\
\hline Felipe Pena & & & & $x$ & \\
\hline Felipe Simão Pontes & & & $x$ & & \\
\hline Fernanda Bruno & $x$ & $x$ & $x$ & & \\
\hline Fernanda Costa e Silva & $x$ & & & & \\
\hline Fernanda de Oliveira Gomes & $x$ & & & & \\
\hline Fernanda Lima Lopes & $x$ & & & & \\
\hline Fernanda Mauricio da Silva & $x$ & & & & $x$ \\
\hline Fernanda Salvo & $x$ & & & & \\
\hline Fernando Andacht & & & $x$ & & \\
\hline Fernando do Nascimento Gonçalves & $x$ & $x$ & & & \\
\hline Fernando Luiz Krüger & & $x$ & & & \\
\hline Fernando Mascarello & & $\mathrm{x}$ & & & \\
\hline Fernando Morais da Costa & $x$ & & & & \\
\hline Fernando Resende & & & $x$ & & \\
\hline Flávia Ataide Pithan & $x$ & & & & \\
\hline Flavia Natércia da Silva Medeiros & & & & $x$ & \\
\hline
\end{tabular}


Anexo 4

\begin{tabular}{|c|c|c|c|c|c|}
\hline Autores & E-Compós & Famecos & Galáxia & Intercom & MATRIZes \\
\hline Flavia Pitaluga & & & $\mathrm{x}$ & & \\
\hline Flávio A.C. Porcello & & $\mathrm{x}$ & & & \\
\hline Flávio Vinicius Cauduro & $x$ & $x$ & $x$ & & \\
\hline Florence Dravet & & $x$ & & & \\
\hline Florentina das Neves Souza & & $x$ & & & \\
\hline Francilaine Munhoz Moraes & $x$ & & & & \\
\hline Francis Lampoglia; & & & $x$ & & \\
\hline Francisco de Assis & & & & $x$ & \\
\hline Francisco E. Menezes Martins & & $x$ & & & \\
\hline Francisco José Castilhos Karam & & $x$ & & & \\
\hline Francisco José Paoliello Pimenta & $x$ & $x$ & & & \\
\hline Francisco Leite & & & $x$ & & \\
\hline Francisco Menezes Martins & $x$ & & & & \\
\hline $\begin{array}{l}\text { Francisco Paulo Jamil Almeida } \\
\text { Marques }\end{array}$ & $\mathrm{x}$ & & $\mathrm{x}$ & $\mathrm{x}$ & \\
\hline Francisco Rüdiger & $x$ & $x$ & $x$ & & $x$ \\
\hline Frederico de Mello Brandão Tavares & $\mathrm{x}$ & $\mathrm{x}$ & $\mathrm{x}$ & & \\
\hline Gabriel Sausen Feil & & & $x$ & & \\
\hline Gabriela Borges & & & $x$ & & \\
\hline Gabriela Reinaldo & & & $x$ & & \\
\hline Geane Alzamora & & & $x$ & & \\
\hline Geísa Mattos & & $x$ & & & \\
\hline Gerson Martins & & & & $\mathrm{x}$ & \\
\hline Gilson Schwartz & $\mathrm{x}$ & & & & \\
\hline Gino Giacomini Filho & & $x$ & & & $x$ \\
\hline Giovandro Marcus Ferreira & & $x$ & & $x$ & \\
\hline Gisela Castro & $x$ & $\mathrm{x}$ & & $x$ & \\
\hline Gislene Silva & $x$ & $x$ & $x$ & & $x$ \\
\hline Gladis Linhares Toniazzo & & & $x$ & & \\
\hline Gláucia Costa de Castro Pimentel & & & $x$ & & \\
\hline Gláucio Aranha & & & $x$ & & \\
\hline Glauco Rodrigues Cortez & $x$ & & $x$ & & \\
\hline Gonzalo Prudkin & $x$ & & & & \\
\hline Gottfried Stockinger & $x$ & & & & \\
\hline Graça Caldas & & & & $x$ & \\
\hline Graciela Ormezzano & & $x$ & & & \\
\hline Gustavo Souza & $x$ & $x$ & $x$ & & \\
\hline Hans-Jürgen Michalski & & & & $x$ & \\
\hline Hélio Ademar Schuch & & & & $\mathrm{x}$ & \\
\hline
\end{tabular}


Anexo 4

Autores

E-Compós Famecos Galáxia Intercom MATRIZes

\begin{tabular}{|c|c|c|c|c|c|}
\hline Heloisa Juncklaus Preis Moraes & & $x$ & & & \\
\hline Heloisa Pait & & $x$ & & & \\
\hline Henrique Antoun & $x$ & $x$ & & & \\
\hline Hérica Lene & $x$ & $x$ & & & \\
\hline Hermílio Santos & & $x$ & & & \\
\hline Herom Vargas & $x$ & & $x$ & & \\
\hline Hugo Lovisolo & & & & $x$ & \\
\hline Humberto Ivan Keske & $x$ & $x$ & & & \\
\hline leda Tucherman & & $\mathrm{x}$ & $x$ & $x$ & \\
\hline Igor Sacramento & $x$ & & & & \\
\hline Ilana Feldman & & $x$ & $x$ & & \\
\hline Iluska Coutinho & & $x$ & & $x$ & \\
\hline Inácio Szabó & $x$ & & & & \\
\hline Inês Hennigen & & $\mathrm{x}$ & & & \\
\hline Inês Sampaio & $x$ & & & & \\
\hline Irene de Araújo Machado & $x$ & $\mathrm{x}$ & & & \\
\hline Isabel Regina Augusto & & & & $x$ & \\
\hline Isabel Travancas & & & & $x$ & \\
\hline Isabelle Anchieta & & & & $x$ & \\
\hline $\begin{array}{l}\text { Isaltina Maria de Azevedo Mello } \\
\text { Gomes }\end{array}$ & & & $x$ & & \\
\hline Ismail Xavier & & & & & $x$ \\
\hline Itania Maria Mota Gomes & $x$ & $x$ & & & \\
\hline Ivan Capeller & & & & & $x$ \\
\hline Ivana Bentes & & & & & $x$ \\
\hline Ivo José Dittrich & & & & $x$ & \\
\hline Ivone de Lourdes Oliveira & & $x$ & & & \\
\hline J.S. Faro & & & $x$ & & \\
\hline Jacques A. Wainberg & & $x$ & & $x$ & \\
\hline Jairo Ferreira & $x$ & & & & \\
\hline Jamile Dalpiaz & & $x$ & & & \\
\hline Janaína Cordeiro Freire & & $x$ & & & \\
\hline Jane Voisin & & & & $x$ & \\
\hline Janice Caiafa & $x$ & $x$ & $x$ & & \\
\hline Jeder Janotti Junior & $x$ & & $x$ & & \\
\hline Jefferson Cabral Azevedo & & & & $x$ & \\
\hline Jefferson O. Goulart & & & & $x$ & \\
\hline Jerusa Pires Ferreira & & & $x$ & & \\
\hline Jiani Adriana Bonin & & $x$ & & & \\
\hline
\end{tabular}


Anexo 4

\begin{tabular}{|c|c|c|c|c|c|}
\hline Autores & E-Compós & Famecos & Galáxia & Intercom & MATRIZes \\
\hline João Freire Filho & $\mathrm{x}$ & $\mathrm{x}$ & $\mathrm{x}$ & & \\
\hline João Guilherme Barone Reis e Silva & & $x$ & & & \\
\hline João José Azevedo Curvello & $x$ & & & & \\
\hline João Maia & $x$ & $x$ & & & \\
\hline João Martins Ladeira & $x$ & $x$ & & $x$ & \\
\hline João Queiroz & & & $\mathrm{x}$ & & \\
\hline Joëlle Rouchou & & & & $x$ & \\
\hline Jorge Antonio Menna Duarte & & & & $x$ & \\
\hline Jorge Borges & & & & $x$ & \\
\hline Jorge Campos & & $x$ & & & \\
\hline Jorge Cardoso Filho & $x$ & & & & \\
\hline Jorge Cláudio Ribeiro & & $x$ & & & \\
\hline Jorge Cunha Cardoso Filho & & & $x$ & & \\
\hline José Cardoso Ferrão Neto & & $x$ & & & \\
\hline José Carlos Ribeiro & $x$ & $x$ & & & \\
\hline José Carlos Rodrigues & & $x$ & & & \\
\hline José Claudio Siqueira Castanheira & $x$ & & & & \\
\hline José Luiz Aidar Prado & $x$ & $x$ & & & $x$ \\
\hline José Luiz Braga & $x$ & & & & $x$ \\
\hline José Luiz Fiorin & & & $x$ & & \\
\hline José Luiz Martinez & & & $x$ & & \\
\hline José Marques de Melo & & $x$ & & $x$ & $x$ \\
\hline Josenildo Guerra & $x$ & & & & \\
\hline Juliana Andrade Leitão & & & & $x$ & \\
\hline Juliana Freire Gutmann & $x$ & & & & \\
\hline Juliana Gagliardi de Araujo & & $x$ & & & \\
\hline Juliana Lúcia Escobar & $x$ & & & & \\
\hline Juliana Tonin & $x$ & $x$ & & & \\
\hline Juliane Noack & & & $x$ & & \\
\hline Juliano Borges & & & & & $x$ \\
\hline Juliano Maurício de Carvalho & $x$ & & & & \\
\hline Julio Bezerra & $x$ & & $x$ & & \\
\hline Julio Pinto & & & $x$ & & $x$ \\
\hline Juremir Machado da Silva & & $x$ & & & $x$ \\
\hline Karla Maria Muller & $x$ & & $x$ & & \\
\hline Karla Schuch Brunet & & $x$ & & $x$ & \\
\hline Katarini Miguel & & & & $x$ & \\
\hline Kati Caetano & & & $\mathrm{x}$ & & \\
\hline Katia Eliana Caetano & $x$ & & & & \\
\hline
\end{tabular}


Anexo 4

Autores

E-Compós Famecos Galáxia Intercom MATRIZes

\begin{tabular}{|c|c|c|c|c|c|}
\hline Kênia Beatriz Ferreira Maia & $x$ & & & & \\
\hline Kleber Mendonça & & $x$ & & & \\
\hline Klondy Lúcia de Oliveira Agra & & $x$ & & & \\
\hline L. Graciela Natansohn & $x$ & & & & \\
\hline Larissa Mendes & & & $x$ & & \\
\hline Laura Loguercio Cánepa & $\mathrm{x}$ & & $\mathrm{x}$ & & \\
\hline Laura Martini Bedran & & & & $x$ & \\
\hline Laura Strelow Storch & $x$ & & & & \\
\hline Lauro Barbosa da Silveira & & & $x$ & & \\
\hline Lavina Madeira Ribeiro & & & $\mathrm{x}$ & & \\
\hline Leandro Colling & & $x$ & & & \\
\hline Leandro Marshall & & $x$ & & & \\
\hline Lebiam Tamar Silva Bezerra & & $x$ & & & \\
\hline Leda Tenório da Motta & & & $x$ & & $x$ \\
\hline Leila Cristina de Mello Darin & & & $x$ & & \\
\hline Leonardo de Marchi & $x$ & $x$ & & & \\
\hline Leonel José de Oliveira & & $x$ & & & \\
\hline Léslie Piccolotto Ferreira & & & $x$ & & \\
\hline Letícia Cantarela Matheus & $x$ & $x$ & & $x$ & \\
\hline Lia Hecker Luz & & $x$ & $x$ & $x$ & \\
\hline Lia Seixas & & & $x$ & & \\
\hline Lígia Campos de Cerqueira Lana & $x$ & & & & \\
\hline Liliana Maria Passerino & $x$ & & & & \\
\hline Liliane da Costa Nascimento & $x$ & & & & \\
\hline Linda Catarina Gualda & & & & & $x$ \\
\hline Lindamir Ester Adamczuk & & & & $x$ & \\
\hline Lírian Sifuentes & & $x$ & & & \\
\hline Lisandro Nogueira & & $x$ & & & \\
\hline Livia Fernandes & & $\mathrm{x}$ & & & \\
\hline Lourdes Gabrielli & & & $x$ & & \\
\hline Lucia Leão & & & $x$ & & \\
\hline Lúcia Santa Cruz & $x$ & & & & \\
\hline Lucia Santaella & $x$ & $x$ & & & $x$ \\
\hline Luciana Coutinho Souza & $x$ & & $x$ & & \\
\hline Luciane Lucas dos Santos & & $x$ & & & \\
\hline Lucília Maria Souza Romão & $x$ & $x$ & & & \\
\hline Lucrécia D’Alessio Ferrara & & $x$ & $x$ & & $x$ \\
\hline Ludmila Brandão & & & $x$ & & \\
\hline Luis Felipe Miguel & & $\mathrm{x}$ & & & \\
\hline
\end{tabular}


Anexo 4

\begin{tabular}{|c|c|c|c|c|c|}
\hline Autores & E-Compós & Famecos & Galáxia & Intercom & MATRIZes \\
\hline Luis Gomes & & $\mathrm{x}$ & & & \\
\hline Luís Mauro Sá Martino & & $x$ & $x$ & & \\
\hline Luisa Paraguai & & $x$ & & & \\
\hline Luiz Ademir de Oliveira & & & & $x$ & \\
\hline Luiz Artur Ferrareto & & $x$ & & $x$ & \\
\hline Luiz C. Martino & $x$ & $\mathrm{x}$ & $x$ & & \\
\hline Luiz Gonzaga Motta & $x$ & $x$ & & $x$ & \\
\hline Luiz Marcelo Robalinho Ferraz & $x$ & & & & \\
\hline Luiz Martins & & & & $x$ & \\
\hline Luiz Vadico & & & $x$ & & \\
\hline Luzia M. Yamashita Deliberador & & & & $x$ & \\
\hline Lydia Barros & $x$ & & & & \\
\hline Magaly Prado & & & & & $x$ \\
\hline Malena Segura Contrera & $\mathrm{x}$ & & & & $x$ \\
\hline Marcel Vieira Barreto Silva & $x$ & & & & \\
\hline Marcello M. Gabbay & $x$ & & & & \\
\hline Marcelo Benevides Lopes & $x$ & & & & \\
\hline Marcelo Bulhões & & $x$ & $x$ & & \\
\hline Marcelo Carvalho & & & $x$ & & \\
\hline Marcelo Carvalho da Silva & $x$ & & & & \\
\hline Marcelo Kischinhevsky & $x$ & $x$ & & & $x$ \\
\hline Marcelo Träsel & $x$ & & & & \\
\hline Marcia Benetti & $x$ & $x$ & $x$ & & $x$ \\
\hline Márcia Franz Amaral & $x$ & & & & \\
\hline Márcia Gomes & & $x$ & & & \\
\hline Márcia Pedroso & & $x$ & & & \\
\hline Marcia Perencin Tondato & & $x$ & & & \\
\hline Márcia Rejane Messa & $\mathrm{x}$ & & & & \\
\hline Marcia Schmitt Veronezi Cappellari & & & & $x$ & \\
\hline Marcio Acselrad & & $x$ & & & \\
\hline Márcio Padrão & $\mathrm{x}$ & & & & \\
\hline Márcio Serelle & & $x$ & & & $x$ \\
\hline Márcio Simeone Henriques & & $x$ & & & \\
\hline Márcio Souza Gonçalves & & $x$ & $x$ & & \\
\hline Marcius Freire & & $x$ & $x$ & & \\
\hline Marco Antonio Franzmann Schuster & & $x$ & & & \\
\hline Marco Antonio Roxo da Silva & & $\mathrm{x}$ & & & \\
\hline Marco Schneider & $\mathrm{x}$ & & $x$ & & \\
\hline Marco Silva & & $x$ & & & \\
\hline
\end{tabular}


Anexo 4

Autores

E-Compós Famecos Galáxia Intercom MATRIZes

\begin{tabular}{|c|c|c|c|c|c|}
\hline Marco Toledo de Assis Bastos & $x$ & $x$ & & & \\
\hline Marcos Braga & $x$ & & & & \\
\hline Marcos Kahtalian & & & $x$ & & \\
\hline Marcos Lopes & & & $x$ & & \\
\hline Marcos Palacios & $x$ & $x$ & & & \\
\hline Marcus Antônio Assis Lima & & & & $x$ & \\
\hline Margarida M. Krohling Kunsch & & & & $x$ & \\
\hline Margarida Maria Knobbe & & $x$ & & & \\
\hline $\begin{array}{l}\text { Maria Aparecida Campos } \\
\text { Mamede-Neves }\end{array}$ & & $x$ & & & \\
\hline Maria Beatriz Furtado Rahde & $x$ & $x$ & & & \\
\hline Maria Carmem Jacob de Souza & $x$ & $x$ & & & \\
\hline Maria Christianni Coutinho Marçal & & $\mathrm{x}$ & & & \\
\hline Maria Clara Aquino & $x$ & & & & \\
\hline Maria Cristina Brandão de Faria & $x$ & & & & \\
\hline Maria Cristina Castilho Costa & & & & $\mathrm{x}$ & $x$ \\
\hline Maria Cristina Franco Ferraz & $x$ & $x$ & & $x$ & \\
\hline Maria Cristina Gobbi & & & & $x$ & \\
\hline Maria da Conceição Golobovante & & $x$ & & & \\
\hline $\begin{array}{l}\text { Maria da Conceição Xavier de } \\
\text { Almeida }\end{array}$ & & $x$ & & & \\
\hline Maria das Graças Targino & & & & $x$ & \\
\hline Maria Eduarda da Mota Rocha & & & $x$ & & \\
\hline Maria Érica Oliveira Lima & & & & & $x$ \\
\hline Maria Helena Steffens de Castro & & $\mathrm{x}$ & & & \\
\hline Maria Immacolata Vassallo de Lopes & $x$ & $x$ & & $x$ & $x$ \\
\hline Maria José Baldessar & & $x$ & & & \\
\hline Maria José Barreras & & $x$ & & & \\
\hline Maria Lília Dias de Castro & $\mathrm{x}$ & & & & \\
\hline Maria Lucia Vissotto Paiva Diniz & & & $x$ & & \\
\hline Maria Luisa Sacknies da Silva & & $x$ & & & \\
\hline Maria Ogécia Drigo & $x$ & $\mathrm{x}$ & $\mathrm{x}$ & & \\
\hline Maria Regina Paula Mota & & & & & $x$ \\
\hline Maria Ribeiro do Valle & & & & $x$ & \\
\hline Maria Salett Tauk Santos & & & & $x$ & \\
\hline Maria Teresa Cardoso de Campos & & & & $x$ & \\
\hline Marialva Barbosa & $x$ & $\mathrm{x}$ & $x$ & & $x$ \\
\hline Mariana Baltar & & $\mathrm{x}$ & & & \\
\hline Marianna Taborda & $x$ & & & & \\
\hline
\end{tabular}


Anexo 4

\begin{tabular}{|c|c|c|c|c|c|}
\hline Autores & E-Compós & Famecos & Galáxia & Intercom & MATRIZes \\
\hline Mariella Silva de Oliveira & & & & $\mathrm{x}$ & \\
\hline Marildo José Nercolini & & $x$ & & & \\
\hline Marilia Fiorillo & & & $x$ & & \\
\hline Marilia Veríssimo Veronese & $x$ & & & & \\
\hline Marina Nascimento Lemos Barboza & & & & $\mathrm{x}$ & \\
\hline Marina Patrício de Arruda & & $x$ & & & \\
\hline Marino Boeira & & $x$ & & & \\
\hline Mario de Carvalho & & $x$ & & & \\
\hline Mario Maciel & & $x$ & & & \\
\hline Marlene Neves Strey & & $x$ & & & \\
\hline Marlson Assis de Araújo & & & & $x$ & \\
\hline Marta Catunda & & $x$ & & & \\
\hline Marta de Araújo Pinheiro & $x$ & $x$ & & & \\
\hline Martin de la Martinière Petroll & & $x$ & & & \\
\hline Massimo Di Felice & & $x$ & & & \\
\hline Mateus Yuri Passos & & & & $\mathrm{x}$ & \\
\hline Maurício Guilherme Silva Jr. & & & $x$ & & \\
\hline Mauricio Reinaldo Gonçalves & & & & $x$ & \\
\hline Mauro Baptista & & & $\mathrm{x}$ & & \\
\hline Mauro César Silveira & & & & $\mathrm{x}$ & \\
\hline Mayka Castellano & $x$ & & & & \\
\hline Mayra Rodrigues Gomes & & $x$ & $x$ & & $x$ \\
\hline Merli Leal Silva & & $x$ & & & \\
\hline Messias Guimarães Bandeira & & $x$ & & & \\
\hline Micael Herschmann & $x$ & $x$ & & & \\
\hline Michael Hanke & & & $x$ & & \\
\hline Miguel Freire & & & & $x$ & \\
\hline $\begin{array}{l}\text { Milena Carvalho Bezerra Freire de } \\
\text { Oliveira-Cruz }\end{array}$ & & & $x$ & & \\
\hline Militão de Maya Ricardo & & $x$ & & & \\
\hline Míriam Cristina Carlos Silva & & & & $x$ & \\
\hline Miriam de Souza Rossini & & $x$ & & & \\
\hline Mirna Feitoza Pereira & & $x$ & $x$ & & \\
\hline Moema Martins Rebouças & & & $x$ & & \\
\hline Mohammed ElHaiii & $\mathrm{x}$ & $x$ & $x$ & & \\
\hline Monica Martinez & & & & $x$ & \\
\hline Mônica Pegurer Caprino & & $x$ & $\mathrm{x}$ & & \\
\hline Muniz Sodré & & $x$ & $x$ & & \\
\hline Narciso Julio Freire Lobo & & & & $x$ & \\
\hline
\end{tabular}


Anexo 4

\section{Autores}

E-Compós Famecos Galáxia Infercom MATRIZes

\begin{tabular}{|c|c|c|c|c|c|}
\hline Nataly de Queiroz Lima & & & & $x$ & \\
\hline Nélia R. Del Bianco & & & & $x$ & \\
\hline Neusa Demartini Gomes & & $x$ & & & \\
\hline Neuza Maria de F. Guareschi & & $x$ & & & \\
\hline Nilda Jacks & $x$ & $x$ & & $x$ & \\
\hline Nina Velasco e Cruz & & & $x$ & & \\
\hline Nízia Vilaça & & $x$ & & & \\
\hline Norberto Kuhn Junior & $x$ & & & $x$ & \\
\hline Norma Discini & & & $x$ & & \\
\hline Olgária Chain Féres Matos & & & $x$ & & \\
\hline Orlando Tambosi & & & & $x$ & \\
\hline Osmar Gonçalves dos Reis Filho & & & $x$ & & \\
\hline Pablo Cezar Laignier & & & & & $x$ \\
\hline Patricia Bandeira de Melo & & $x$ & & & \\
\hline Patrícia Burrowes & & $x$ & & & \\
\hline Patricia Moran & & $x$ & & & \\
\hline Patricia Wittenberg & & & & $x$ & \\
\hline Paula Guimarães Simões & $x$ & & & & \\
\hline Paula Jung Rocha & $x$ & $\mathrm{x}$ & & & \\
\hline Paula Puliti & $x$ & & & & \\
\hline Paula Regina Puhl & $x$ & $x$ & & & \\
\hline Paula Sibilia & & $x$ & & & $x$ \\
\hline Paulo B.C. Schettino & & $x$ & & & \\
\hline Paulo C. Cunha Filho & & $x$ & & & \\
\hline Paulo da Rocha Dias & & & & $x$ & \\
\hline Paulo de Jesus & & & & $x$ & \\
\hline Paulo Moura & & $x$ & & & \\
\hline Paulo Pinheiro & & $x$ & & & \\
\hline Paulo Roberto Massalla Lopes & $x$ & & & & \\
\hline Paulo Vaz & $x$ & $x$ & & & \\
\hline Paulo Vinícius Baptista da Silva & & & & $x$ & \\
\hline Pedro Celso Campos & & & $x$ & & \\
\hline Pedro Henrique Reis & & & $x$ & & \\
\hline Pedro Vinicius Asterito Lapera & $x$ & & & & \\
\hline Potiguara Mendes da Silveira Jr. & & $x$ & & & \\
\hline Priscila Monteiro Borges & & & $x$ & & \\
\hline Rafael de Luna Freire & & & $x$ & & \\
\hline Rafael Fortes & $x$ & $x$ & & $x$ & \\
\hline Raquel da Cunha Recuero & $\mathrm{x}$ & $\mathrm{x}$ & & & \\
\hline
\end{tabular}


Anexo 4

\begin{tabular}{|c|c|c|c|c|c|}
\hline Autores & E-Compós & Famecos & Galáxia & Intercom & MATRIZes \\
\hline Raquel Longhi & & $\mathrm{x}$ & & & \\
\hline Raquel Paiva & & $x$ & $x$ & & $x$ \\
\hline Rebeca Recuero Rebs & & & & $x$ & \\
\hline Reges Toni Schwaab & & & $x$ & & \\
\hline Regina Gloria Nunes de Andrade & & & & $x$ & \\
\hline Regina Helena Silva & $x$ & & & & \\
\hline Regina Rossetti & $x$ & & $x$ & & \\
\hline Renata Lemos & & & $x$ & & \\
\hline Renata Maria do Amaral & $x$ & & & & \\
\hline Renata Pitombo Cidreira & & $x$ & & & \\
\hline Renato Cordeiro Gomes & $x$ & & & & \\
\hline Renato Luiz Pucci Jr. & $x$ & & & & $x$ \\
\hline Renné Oliveira França & $x$ & & & & \\
\hline Renzo Taddei & & & $x$ & & \\
\hline Ricardo Fabrino Mendonça & $x$ & $x$ & & $x$ & \\
\hline Ricardo Ferreira Freitas & & $x$ & & & \\
\hline Robéria Nádia Araújo Nascimento & & $x$ & & & \\
\hline Roberta Manuela Barros de Andrade & $x$ & $\mathrm{x}$ & & $x$ & \\
\hline Roberto Alves Reis & & $x$ & & & \\
\hline Roberto Elísio dos Santos & & $x$ & & $x$ & \\
\hline Roberto José Ramos & & $\mathrm{x}$ & & & \\
\hline Roberto Porto Simões & & $x$ & & & \\
\hline Roberto Ramos & & $x$ & & & \\
\hline Roberto Tietzmann & $x$ & & & & \\
\hline Robson Santos de Oliveira & & & & $x$ & \\
\hline Rodrigo Carreiro & $x$ & & & & \\
\hline Rodrigo Fonseca e Rodrigues & & $x$ & & & \\
\hline Rodrigo Jacobus & & & & $x$ & \\
\hline Rodrigo Travitzki & $x$ & & & & \\
\hline Rogério Christofoletti & & $x$ & & $x$ & \\
\hline Rogério da Costa & & $x$ & $x$ & & \\
\hline Rogério Luiz Covaleski & & & $x$ & & \\
\hline Ronaldo Bispo & & & $x$ & & \\
\hline Ronaldo Entler & & & $x$ & & \\
\hline Ronaldo Helal & & & & $\mathrm{x}$ & \\
\hline Ronaldo Henn & $x$ & & & & \\
\hline Ronize Aline Matos de Abreu & & & & $x$ & \\
\hline Rosa Lucila Fernandes Y Freitas & & $x$ & & & \\
\hline Rosana de Lima Soares & $x$ & & $x$ & & $\mathrm{x}$ \\
\hline
\end{tabular}


Anexo 4

\begin{tabular}{|c|c|c|c|c|c|}
\hline Autores & E-Compós & Famecos & Galáxia & Intercom & MATRIZes \\
\hline Rose de Melo Rocha & $x$ & $x$ & & & \\
\hline Rose Mary Gonçalves & & & & $x$ & \\
\hline Roseane Andrelo & & $x$ & & & \\
\hline Roseli Figaro & $x$ & & & & \\
\hline Roseméri Laurindo & & & & $x$ & \\
\hline Rudinei Kopp & & $x$ & & & \\
\hline Samile Vanz & & $x$ & & & \\
\hline Sandra Bordini Mazzocato & $x$ & & & & \\
\hline Sandra Fischer & $x$ & & & & \\
\hline Sandra Gonçalves & $x$ & & & & \\
\hline Sandra Maria Ribeiro de Souza & & & & $x$ & $x$ \\
\hline Sandra Montardo & $x$ & $x$ & & $x$ & \\
\hline Sandra Reimão & & & & $x$ & $x$ \\
\hline Sandra Souza & & & $x$ & & \\
\hline Sara Alves Feitosa & & $x$ & & & \\
\hline Sebastião Carlos de Morais Squirra & & $x$ & & & \\
\hline Sebastião Guilherme Albano da Costa & $x$ & $x$ & & & \\
\hline Sergio Amadeu da Silveira & & $\mathrm{x}$ & & & \\
\hline Sérgio Capareli & & $x$ & & $x$ & \\
\hline Sérgio Luiz Gadini & & $\mathrm{x}$ & & & \\
\hline Sheila Schvarzman & & & $x$ & & \\
\hline Sheila Vieira de Camargo Grillo & & & & $x$ & \\
\hline Sibila Rocha & $x$ & & & & \\
\hline Sidney Ferreira Leite & $\mathrm{x}$ & $\mathrm{x}$ & & & \\
\hline Sidney Molina & & & $x$ & & \\
\hline Silnei Scharten Soares & $x$ & & & & \\
\hline Silvana Macêdo & & & $x$ & & \\
\hline Silvia Cristina Jardim & & $\mathrm{x}$ & & & \\
\hline Silvia Garcia Nogueira & & $x$ & & $x$ & \\
\hline Simone Antoniaci Tuzzo & & & & $\mathrm{x}$ & \\
\hline Simone do Vale & $x$ & & & & \\
\hline Simone Luci Pereira & $x$ & & & & \\
\hline Simone Maria Andrade Pereira de Sá & & & $x$ & & \\
\hline Simone Maria da Rocha & $x$ & $x$ & $x$ & & \\
\hline Simone Pereira de Sá & $x$ & $x$ & & & \\
\hline Solange Martins Couceiro de Lima & & & & $x$ & \\
\hline Solange Wajnman & & $x$ & & & \\
\hline Sônia Bertol & & $x$ & & & \\
\hline Sônia Régis & & & $x$ & & \\
\hline
\end{tabular}


Anexo 4

\begin{tabular}{|c|c|c|c|c|c|}
\hline Autores & E-Compós & Famecos & Galáxia & Intercom & MATRIZes \\
\hline Sonia Virgínia Moreira & & & & $\mathrm{x}$ & \\
\hline Suely Fragoso & $x$ & & $x$ & & $x$ \\
\hline Susana Gastal & & $x$ & & & \\
\hline Suzana Kilpp & $x$ & $x$ & $x$ & $x$ & $x$ \\
\hline Suzy dos Santos & $x$ & & & & \\
\hline Tania Fraga & & & $x$ & & \\
\hline Tânia Maria Cezar Hoff & $x$ & & & & \\
\hline Tânia Pitta & & $x$ & & & \\
\hline Tarcisio Torres Silva & & & $x$ & & \\
\hline Tarcyane Cajueiro dos Santos & & $x$ & $x$ & & \\
\hline Telma Johnson & $x$ & & & & \\
\hline Teresinha Maria de C. Cruz Pires & $x$ & & & & \\
\hline Thaís de Mendonça Jorge & & $x$ & & & \\
\hline Thiago Soares & $x$ & & & & \\
\hline Tiago José Lemos Monteiro & $x$ & & & & $x$ \\
\hline Tiago Mainieri & & $x$ & & & \\
\hline Urbano Zilles & & $x$ & & & \\
\hline Valdenise Schmitt & $x$ & & & & \\
\hline Valdir José Morigi & $x$ & & & & \\
\hline Valéria dos Santos Guimarães & & & $x$ & & \\
\hline Valério Cruz Brittos & & $x$ & & $x$ & \\
\hline Vander Casaqui & $x$ & & $x$ & & \\
\hline Veneza V. Mayora Ronsini & $x$ & & & $x$ & \\
\hline Vera França & & & $x$ & & \\
\hline Vera Lúcia Follain de Figueiredo & & & $x$ & & $x$ \\
\hline Vera Regina Serezer Gerzson & & $x$ & & & \\
\hline Vera Veiga França & & $x$ & & & \\
\hline Veruska Sayonara de Góis & & & & $x$ & \\
\hline Vicente William da Silva Darde & & & $x$ & & \\
\hline Victa de Carvalho & & & $x$ & & \\
\hline Victor Gentilli & & $x$ & & & \\
\hline Vilso Junior Chierentin & & & $x$ & & \\
\hline Vinícius Andrade Pereira & & $x$ & & & \\
\hline Vinícius V. M. Ferreira & & & & $x$ & \\
\hline Virgínia Fonseca Antonine & & $x$ & & & \\
\hline Virgínia Pontual & & $x$ & & & \\
\hline Virginia Pradelina da Silveira Fonseca & $x$ & $\mathrm{x}$ & & & \\
\hline Vivian Lemes Moreira & $x$ & & & & \\
\hline Viviane Borelli & $x$ & & & & \\
\hline
\end{tabular}


Anexo 4

Autores

E-Compós Famecos Galáxia Intercom MATRIZes

\begin{tabular}{|c|c|c|c|c|c|}
\hline Waldemar Luiz Kunsch & & & & $x$ & \\
\hline Waldomiro Vergueiro & & & & & $x$ \\
\hline Walter Teixeira Lima Junior & $x$ & $x$ & $x$ & & \\
\hline Wellington Pereira & & $\mathrm{x}$ & & & \\
\hline Wilson Gomes & & $x$ & & & \\
\hline Wilton Garcia & & & $x$ & & \\
\hline Winfried Nöth & & & $x$ & & $x$ \\
\hline Yuji Gushiken & $x$ & & & & \\
\hline Yvana Fechine & $x$ & $x$ & $x$ & & \\
\hline
\end{tabular}

